Cochrane Database of Systematic Reviews

\title{
Drugs for treating Buruli ulcer (Mycobacterium ulcerans disease)
} (Review)

Yotsu RR, Richardson M, Ishii N

Yotsu RR, Richardson M, Ishii N.

Drugs for treating Buruli ulcer (Mycobacterium ulcerans disease).

Cochrane Database of Systematic Reviews 2018, Issue 8. Art. No.: CD012118.

DOI: 10.1002/14651858.CD012118.pub2.

www.cochranelibrary.com 
TABLE OF CONTENTS

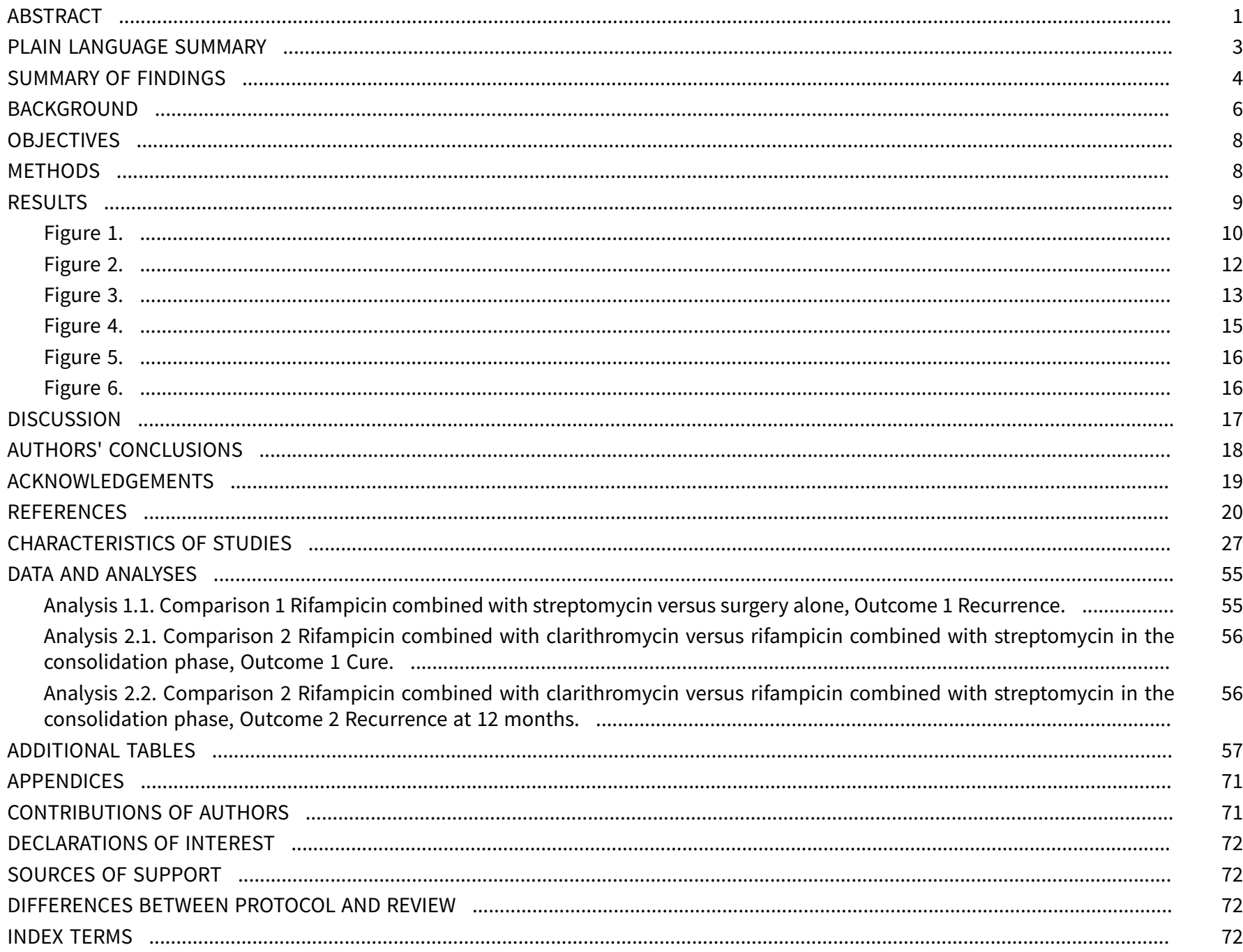

Drugs for treating Buruli ulcer (Mycobacterium ulcerans disease) (Review) 
[Intervention Review]

\section{Drugs for treating Buruli ulcer (Mycobacterium ulcerans disease)}

Rie R Yotsu ${ }^{1,2}$, Marty Richardson ${ }^{3}$, Norihisa Ishii 4

1Department of Dermatology, National Center for Global Health and Medicine, Tokyo, Japan. 2Department of Dermatology, National Suruga Sanatorium, Shizuoka, Japan. ${ }^{3}$ Cochrane Infectious Diseases Group, Liverpool School of Tropical Medicine, Liverpool, UK.

${ }^{4}$ Leprosy Research Center, National Institute of Infectious Diseases, Tokyo, Japan

Contact: Rie R Yotsu, Department of Dermatology, National Center for Global Health and Medicine, 1-21-1 Toyama, Shinjuku-ku, Tokyo, 162-8655, Japan. yotsurie@hotmail.com.

Editorial group: Cochrane Infectious Diseases Group.

Publication status and date: Unchanged, published in Issue 8, 2018.

Citation: Yotsu RR, Richardson M, Ishii N. Drugs for treating Buruli ulcer (Mycobacterium ulcerans disease). Cochrane Database of Systematic Reviews 2018, Issue 8. Art. No.: CD012118. DOI: 10.1002/14651858.CD012118.pub2.

Copyright ( 2018 The Authors. Cochrane Database of Systematic Reviews published by John Wiley \& Sons, Ltd. on behalf of The Cochrane Collaboration. This is an open access article under the terms of the Creative Commons Attribution-Non-Commercial Licence, which permits use, distribution and reproduction in any medium, provided the original work is properly cited and is not used for commercial purposes.

\section{A B S T R A C T}

\section{Background}

Buruli ulcer is a necrotizing cutaneous infection caused by infection with Mycobacterium ulcerans bacteria that occurs mainly in tropical and subtropical regions. The infection progresses from nodules under the skin to deep ulcers, often on the upper and lower limbs or on the face. If left undiagnosed and untreated, it can lead to lifelong disfigurement and disabilities. It is often treated with drugs and surgery.

\section{Objectives}

To summarize the evidence of drug treatments for treating Buruli ulcer.

\section{Search methods}

We searched the Cochrane Infectious Diseases Group Specialized Register; the Cochrane Central Register of Controlled Trials (CENTRAL), published in the Cochrane Library; MEDLINE (PubMed); Embase (Ovid); and LILACS (Latin American and Caribbean Health Sciences Literature; BIREME). We also searched the US National Institutes of Health Ongoing Trials Register (clinicaltrials.gov) and the World Health Organization (WHO) International Clinical Trials Registry Platform (ICTRP) (www.who.int/ictrp/search/en/). All searches were run up to 19 December 2017. We also checked the reference lists of articles identified by the literature search, and contacted leading researchers in this topic area to identify any unpublished data.

\section{Selection criteria}

We included randomized controlled trials (RCTs) that compared antibiotic therapy to placebo or alternative therapy such as surgery, or that compared different antibiotic regimens. We also included prospective observational studies that evaluated different antibiotic regimens with or without surgery.

\section{Data collection and analysis}

Two review authors independently applied the inclusion criteria, extracted the data, and assessed methodological quality. We calculated the risk ratio (RR) for dichotomous data with 95\% confidence intervals (CI). We assessed the certainty of the evidence using the GRADE approach. 


\section{Main results}

We included a total of 18 studies: five RCTs involving a total of 319 participants, ranging from 12 participants to 151 participants, and 13 prospective observational studies, with 1665 participants. Studies evaluated various drugs usually in addition to surgery, and were carried out across eight countries in areas with high Buruli ulcer endemicity in West Africa and Australia. Only one RCT reported adequate methods to minimize bias. Regarding monotherapy, one RCT and one observational study evaluated clofazimine, and one RCT evaluated sulfamethoxazole/trimethoprim. All three studies had small sample sizes, and no treatment effect was demonstrated. The remaining studies examined combination therapy.

\section{Rifampicin combined with streptomycin}

We found one RCT and six observational studies which evaluated rifampicin combined with streptomycin for different lengths of treatment (2, 4, 8, or 12 weeks) (941 participants). The RCT did not demonstrate a difference between the drugs added to surgery compared with surgery alone for recurrence at 12 months, but was underpowered (RR $0.12,95 \% \mathrm{Cl} 0.01$ to $2.51 ; 21$ participants; very low-certainty evidence).

An additional five single-arm observational studies with 828 participants using this regimen for eight weeks with surgery (given to either all participants or to a select group) reported healing rates ranging from $84.5 \%$ to $100 \%$, assessed between six weeks and one year. Four observational studies reported healing rates for participants who received the regimen alone without surgery, reporting healing rates ranging from $48 \%$ to $95 \%$ assessed between eight weeks and one year.

\section{Rifampicin combined with clarithromycin}

Two observational studies administered combined rifampicin and clarithromycin. One study evaluated the regimen alone (no surgery) for eight weeks and reported a healing rate of $50 \%$ at 12 months (30 participants). Another study evaluated the regimen administered for various durations (as determined by the clinicians, durations unspecified) with surgery and reported a healing rate of $100 \%$ at 12 months (21 participants).

\section{Rifampicin with streptomycin initially, changing to rifampicin with clarithromycin in consolidation phase}

One RCT evaluated this regimen (four weeks in each phase) against continuing with rifampicin and streptomycin in the consolidation phase (total eight weeks). All included participants had small lesions, and healing rates were above $90 \%$ in both groups without surgery (healing rate at 12 months RR $0.94,95 \% \mathrm{Cl} 0.87$ to 1.03 ; 151 participants; low-certainty evidence). One single-arm observational study evaluating the substitution of streptomycin with clarithromycin in the consolidation phase ( 6 weeks, total 8 weeks) without surgery given to a select group showed a healing rate of $98 \%$ at 12 months (41 participants).

\section{Novel combination therapy}

Two large prospective studies in Australia evaluated some novel regimens. One study evaluating rifampicin combined with either ciprofloxacin, clarithromycin, or moxifloxacin without surgery reported a healing rate of $76.5 \%$ at 12 months ( 132 participants). Another study evaluating combinations of two to three drugs from rifampicin, ciprofloxacin, clarithromycin, ethambutol, moxifloxacin, or amikacin with surgery reported a healing rate of $100 \%$ (90 participants).

Adverse effects were reported in only three RCTs (158 participants) and eight prospective observational studies (878 participants), and were consistent with what is already known about the adverse effect profile of these drugs. Paradoxical reactions (clinical deterioration after treatment caused by enhanced immune response to M ulcerans) were evaluated in six prospective observational studies ( 822 participants), and the incidence of paradoxical reactions ranged from $1.9 \%$ to $26 \%$.

\section{Authors' conclusions}

While the antibiotic combination treatments evaluated appear to be effective, we found insufficient evidence showing that any particular drug is more effective than another. How different sizes, lesions, and stages of the disease may contribute to healing and which kind of lesions are in need of surgery are unclear based on the included studies. Guideline development needs to consider these factors in designing practical treatment regimens. Forthcoming trials using clarithromycin with rifampicin and other trials of new regimens that also address these factors will help to identify the best regimens.

26 March 2019

Up to date

All studies incorporated from most recent search

All eligible published studies found in the last search (19 Dec, 2017) were included and two ongoing studies have been identified (see 'Characteristics of ongoing studies' section)

Drugs for treating Buruli ulcer (Mycobacterium ulcerans disease) (Review) 


\section{PLAIN LANGUAGE SUMMARY}

\section{Drugs for treating Buruli ulcer (Mycobacterium ulcerans disease)}

\section{What was the aim of this review?}

The aim of this Cochrane Review was to summarize the evidence for drug treatments for Buruli ulcer.

\section{Key messages}

Antibiotics are an important component of treatment of Buruli ulcers, but there is no evidence to suggest that any particular drug is more effective than another.

\section{What was studied in the review?}

Buruli ulcer is a disease caused by mycobacterium (tuberculosis and leprosy are other types of diseases caused by mycobacterium), which results in lumps in the skin and deep ulcers, often on the arms or the face. When diagnosed late, those affected may be left with lifelong disfigurements and disabilities. The disease is most prevalent in West Africa, but it is also found in non-tropical areas including Australia and Japan. It is often treated with drugs and surgery. This review compared different drug treatments for Buruli ulcer.

\section{What are the main results of the review?}

We included 18 studies from eight countries in West Africa and Australia (1984 participants). Antibiotic combination treatments evaluated appear to be effective, but the evidence is insufficient to show that any particular drug is more effective than another.

Testing treatments in Buruli ulcer is challenging as different sizes, lesions, and stages of the disease contribute to healing rates. Surgery also plays an important role in treating Buruli ulcer, and consequently the independent effect of drugs is difficult to assess. Trials of new regimens that also address these factors will help to identify the best regimens.

\section{How up-to-date is this review?}

We searched for studies published up to 19 December 2017. 


\section{SUMMARY OF FINDINGS}

\section{Summary of findings for the main comparison. Rifampicin combined with streptomycin compared with surgery alone for Buruli ulcer}

Rifampicin combined with streptomycin compared with surgery alone for Buruli ulcer

Patient or population: people with Buruli ulcer, non-ulcerated lesions measuring less than $10 \mathrm{~cm}$ in diameter, aged 15 years or older

Settings: Ghana

Intervention: rifampicin combined with streptomycin

Comparison: surgery alone

\begin{tabular}{|c|c|c|c|c|c|c|}
\hline \multirow[t]{3}{*}{ Outcomes } & \multicolumn{2}{|c|}{ Illustrative comparative risks* $(95 \% \mathrm{CI})$} & \multirow{3}{*}{$\begin{array}{l}\text { Relative effect } \\
(95 \% \mathrm{Cl})\end{array}$} & \multirow{3}{*}{$\begin{array}{l}\text { Number of par- } \\
\text { ticipants } \\
\text { (studies) }\end{array}$} & \multirow{3}{*}{$\begin{array}{l}\text { Certainty of the evidence } \\
\text { (GRADE) }\end{array}$} & \multirow[t]{3}{*}{ Comments } \\
\hline & Assumed risk & Corresponding risk & & & & \\
\hline & Surgery alone & $\begin{array}{l}\text { Surgery plus rifampicin combined with } \\
\text { streptomycin }\end{array}$ & & & & \\
\hline $\begin{array}{l}\text { Recurrence, } \\
12 \text { months }\end{array}$ & 20 per 100 & $\begin{array}{l}2.4 \text { per } 100 \\
(<1 \text { to } 50)\end{array}$ & $\begin{array}{l}\mathbf{R R} \mathbf{0 . 1 2}(0.01 \text { to } \\
2.51)\end{array}$ & $\begin{array}{l}21 \text { participants } \\
(1 \text { trial) }\end{array}$ & $\begin{array}{l}\oplus \ominus \ominus \ominus \\
\text { VERY LOWa,b } \\
\text { due to risk of bias and im- } \\
\text { precision }\end{array}$ & $\begin{array}{l}\text { We do not know if } \\
\text { the treatment re- } \\
\text { duces recurrence. }\end{array}$ \\
\hline
\end{tabular}

*The basis for the assumed risk (for example, the median control group risk across studies) is provided in footnotes. The corresponding risk (and its $95 \% \mathrm{Cl}$ ) is based on the assumed risk in the comparison group and the relative effect of the intervention (and its $95 \% \mathrm{Cl}$ ).

Abbreviations: $\mathrm{Cl}$ : confidence interval; RR: risk ratio

GRADE Working Group grades of evidence

High certainty: further research is very unlikely to change our confidence in the estimate of effect.

Moderate certainty: further research is likely to have an important impact on our confidence in the estimate of effect and may change the estimate.

Low certainty: further research is very likely to have an important impact on our confidence in the estimate of effect and is likely to change the estimate.

Very low certainty: we are very uncertain about the estimate.

aDowngraded by 1 for risk of bias: study small and not concealed.

bowngraded by 2 for imprecision: very few events and wide Cls.

Summary of findings 2. Rifampicin with clarithromycin compared with rifampicin with streptomycin in the consolidation phase for Buruli ulcer

Rifampicin with clarithromycin compared with rifampicin with streptomycin in the consolidation phase for Buruli ulcer 
Patient or population: people with Buruli ulcer, early lesions measuring less than $10 \mathrm{~cm}$ in diameter, aged 5 years or older Settings: Ghana

Intervention: rifampicin with streptomycin, followed by rifampicin with clarithromycin after 4 weeks

Comparison: rifampicin with streptomycin continued

\begin{tabular}{|c|c|c|c|c|c|c|}
\hline \multirow[t]{3}{*}{ Outcomes } & \multicolumn{2}{|c|}{ Illustrative comparative risks ${ }^{\star}(95 \% \mathrm{CI})$} & \multirow{3}{*}{$\begin{array}{l}\text { Relative effect } \\
(95 \% \mathrm{Cl})\end{array}$} & \multirow{3}{*}{$\begin{array}{l}\text { Number of par- } \\
\text { ticipants } \\
\text { (studies) }\end{array}$} & \multirow{3}{*}{$\begin{array}{l}\text { Certainty of the evi- } \\
\text { dence } \\
\text { (GRADE) }\end{array}$} & \multirow[t]{3}{*}{ Comments } \\
\hline & Assumed risk & Corresponding risk & & & & \\
\hline & $\begin{array}{l}\text { Streptomycin contin- } \\
\text { ued }\end{array}$ & Clarithromycin substitute & & & & \\
\hline Cure ${ }^{a}$ & 96 per 100 & $\begin{array}{l}90 \text { per } 100 \\
\text { (84 to } 99 \text { ) }\end{array}$ & $\begin{array}{l}\text { RR } 0.94 \\
\text { (0.87 to } 1.03 \text { ) }\end{array}$ & $\begin{array}{l}151 \\
(1 \text { trial) }\end{array}$ & $\begin{array}{l}\oplus \oplus \odot \odot \\
\text { LOWb } \\
\text { due to imprecision }\end{array}$ & $\begin{array}{l}\text { We do not know if the } \\
\text { treatment is superior } \\
\text { to the control. }\end{array}$ \\
\hline
\end{tabular}

*The basis for the assumed risk (for example, the median control group risk across studies) is provided in footnotes. The corresponding risk (and its $95 \% \mathrm{Cl}$ ) is based on the assumed risk in the comparison group and the relative effect of the intervention (and its $95 \% \mathrm{Cl}$ ).

Abbreviations: $\mathrm{Cl}$ : confidence interval; $\mathrm{RR}$ : risk ratio

GRADE Working Group grades of evidence

High certainty: further research is very unlikely to change our confidence in the estimate of effect.

Moderate certainty: further research is likely to have an important impact on our confidence in the estimate of effect and may change the estimate.

Low certainty: further research is very likely to have an important impact on our confidence in the estimate of effect and is likely to change the estimate.

Very low certainty: we are very uncertain about the estimate.

${ }^{a}$ Cure is defined as "healing of skin lesions without recurrence at 12 months or longer." There were no recurrences in this study.

bDowngraded by 2 for imprecision: very few events and wide Cls. 


\section{B A C K G R O U N D}

Buruli ulcer is a necrotizing cutaneous infection caused by infection with Mycobacterium ulcerans bacteria, which is categorized as a non-tuberculous mycobacterium. It is an emerging disease first described by MacCallum 1948 in six Australian patients. The disease was named after Buruli County in Uganda, where a large number of cases were reported in the 1960s (Clancey 1961; Uganda Buruli Group 1970). Since then, the number of Buruli ulcer cases has gradually increased (Yotsu 2015). In spite of this, the disease is still poorly understood, especially its transmission mode. Several studies have demonstrated that the infection is linked to aquatic environments (Lunn 1965; Bradley 1971; Marsollier 2002; Eddyani 2004; Johnson 2005b). However, the natural reservoir and mode of transmission of the infection remain a mystery and may differ between endemic foci worldwide (Merritt 2010).

Currently, over 33 countries worldwide report cases of Buruli ulcer, mainly in people living in tropical and subtropical regions (WHO 2013). About 2000 to 5000 new cases are reported annually, mostly in countries in West and Central Africa (WHO 2013). Most people who are infected in these countries are children aged under 15 years, living in remote rural areas with limited access to health facilities (Marston 1995; Asiedu 1998; Phanzu 2006; WansbroughJones 2006). Other important foci include Australia (Boyd 2012; Tai 2018), French Guiana (Couppié 2015), Papua New Guinea (Igo 1988; Joseph 2003), and more recently, Japan (Yotsu 2012). In addition, a number of cases have been reported in international travellers from non-endemic areas, including North America and European countries (van Oye 1950; Farber 1967; Bär 1998; Semret 1999; Faber 2000; Evans 2003; Ezzedine 2009). Nevertheless, awareness and knowledge of the disease among health practitioners and the community are still lacking, hence the possibility of hidden unreported cases (WHO 2013). In endemic countries, poor health infrastructure and geographical challenges also contribute to the underreporting of cases (WHO 2013). If left undiagnosed and untreated, the disease can lead to lifelong disfigurement and disabilities, which impact greatly on the lives of those affected, especially in resource-poor conditions where most of these people reside.

\section{Description of the condition}

The subcutaneous tissue is the primary site of infection by $M$ ulcerans (van der Werf 1999). The bacteria produce mycolactone, an immunomodulatory macrolide toxin, which is the main pathogenic factor of the disease. This toxin induces tissue necrosis, particularly in subcutaneous fat (van der Werf 2003). Initially, the disease presents as a nodule, papule, plaque (firm, painless, and raised lesion, which is larger than a papule), or oedema, which when left alone eventually breaks open the skin and forms an ulcer. A typical ulcer usually has necrotic slough, undermined edges, and is often painless (unless complicated with a secondary infection) (van der Werf 1999). M ulcerans infection often affects the upper and lower limbs and the face, as these are exposed body areas. It can progress sideways to become a larger lesion involving the joints, as well as deeper into the tissue and cause osteomyelitis in some cases. However, it is rare for the infection to disseminate systemically and cause death (Sizaire 2006). If death occurs, it is usually related to sepsis from a secondary infection or tetanus (van der Werf 1999).

The World Health Organization (WHO) has classified Burui ulcer lesions into three groups according to important clinical features and size, with implications for their management (WHO 2012). Category 1 is a small, early lesion less than $5 \mathrm{~cm}$ in diameter; category II is a lesion of 5 to $15 \mathrm{~cm}$ in diameter; and category III is a lesion more than $15 \mathrm{~cm}$ in diameter, multiple lesions, or lesion(s) at a critical site (eye, breast, genitalia) and osteomyelitis (WHO 2012). Some people experience spontaneous healing during the course of the disease, but the mechanism for this is unclear (Johnson 2005a; Gordon 2011). In severe cases, lifelong sequelae may develop. Vincent 2014a reported that among their 1043 laboratory-confirmed cases of Buruli ulcers in Benin, 229 people (22\%) developed permanent functional impairment one year after their treatment.

The association between Buruli ulcer and HIV/AIDS is not yet clear; there have been some reports on the possible increased rate of infection and severity in those with HIV/AIDS (Vincent 2014b; Tuffour 2015).

\section{Diagnosis}

Buruli ulcer possesses characteristic clinical features, and hence clinical diagnosis is possible to a certain extent in endemic areas. However, for definitive diagnosis, laboratory microbiological methods are required, including Ziehl-Neelsen (ZN) staining for detecting acid-fast bacilli (AFB), in vitro culture, polymerase chain reaction (PCR) assay targeting genomic region IS2404, and histopathology. Findings from at least one of these laboratory microbiological methods should be suggestive of Buruli ulcer to confirm diagnosis (WHO 2014). Samples can be obtained by fine-needle aspiration from a non-ulcerative lesion, and purulent discharge fluid or swab from the undermined wound edge of an ulcerative lesion. Skin biopsy is a reliable sample source, but this can only be performed with adequate skills, tools, and hygienic environment, which may be limited in places where Buruli ulcer is endemic. The WHO is currently promoting PCR confirmation for at least $70 \%$ of all reported cases of Buruli ulcer (WHO 2014).

\section{Description of the intervention}

Since the first description of the disease in 1948, the standard treatment for Buruli ulcers was extensive surgical debridement of affected skin and surrounding tissue, with or without subsequent skin grafting (Darie 1994; van der Werf 2003). However, surgical treatment alone was insufficient to eradicate all the $M$ ulcerans bacteria, and recurrence was common. Although the recurrence rate varied between studies, it was reported to be from $6 \%$ to 32\% (Amofah 1998; Kanga 2003; Debacker 2005; Kibadi 2006; O'Brien 2013a). Moreover, surgery is available only to a small fraction of the population in the most affected areas of low- and middle-income countries due to limited hospital capacities, and difficulties relating to accessibility and cost (WHO 2004). Lesion site is another challenge. If the ulcer involves the face, joints, or other important body parts, which is not a rare occurrence in people with Buruli ulcer, surgical excision may cause disfiguring or disabling consequences (Sizaire 2006). For these reasons, there has been a continuous exploration for other medical approaches that can effectively cure Buruli ulcer, including topical treatments using nitrogen oxide (Phillips 2004a; Phillips 2004b), phenytoin powder (Klutse 2003), local heat treatment (Meyers 1974; Krieg 1979; Junghanss 2009; Vogel 2016), hyperbaric oxygen therapy (Krieg 1975; Krieg 1979), and antibiotic treatments (WHO 2004; WHO 2012; WHO 2017).

Drugs for treating Buruli ulcer (Mycobacterium ulcerans disease) (Review) 
Several trials of different antibiotic treatments have been conducted, including clofazimine and sulfamethoxazole/ trimethoprim (Revill 1973; Fehr 1994), but results of these monotherapies were disappointing. Rifampicin, when used alone, caused the development of a rifampicin-resistant $M$ ulcerans strain in a mice model, suggesting that it should never be used as monotherapy in people, as in people with tuberculosis (TB) or leprosy (Marsollier 2003). In 2004, based on in vitro findings and pilot clinical studies, the WHO introduced a combination of rifampicin (10 mg/kg orally once daily) and streptomycin (15 $\mathrm{mg} / \mathrm{kg}$ intramuscularly once daily) for eight weeks (critical base drugs in TB) as a first-line therapy for people with Buruli ulcer (WHO 2004), which has greatly simplified the treatment and delivery of care for those affected. Nevertheless, surgical treatment adjunctive to antibiotics still plays an important role in Buruli ulcer management, especially for people with severe, large ulcers. The WHO recommends surgical intervention for category III cases and some category II cases, following careful assessment of the efficacy of the antibiotic treatment. In Buruli ulcer, surgical debridement is performed extensively with a wide margin, as mycolactone exists in the subcutaneous fat tissue beyond the wound edges.

Despite antibiotic treatment being effective to an extent, some concerns remain with the current recommended regimen. Streptomycin requires intramuscular injection, which is invasive, therefore patient acceptance and adherence are affected. It is also operationally demanding and of limited availability to people living in remote areas where Buruli ulcer is most endemic, especially rural Africa. Additionally, in these areas, administration of drugs by injection carries the risk of HIV transmission. Potential adverse effects from streptomycin, including ototoxicity and nephrotoxicity, are another concern. There is also concern about encouraging the development of multidrug-resistant TB, as both rifampicin and streptomycin are also effective antituberculosis drugs. Active TB would need to be confidently ruled out before treatment, and considering that this judgement may not always be completely accurate, there may be substantial consequences for the future of TB treatment. The search for a fully orally administered treatment regimen to replace rifampicin and streptomycin combination for the treatment of Buruli ulcer is thus ongoing. Several options have already been explored as replacements for the curative rifampicin and streptomycin combination, including: rifampicin and dapsone (Espey 2002), rifampicin and clarithromycin (BURULICO Study 2010; Chauty 2011; Phillips 2014a; Friedman 2016), rifampicin and ciprofloxacin (O'Brien 2012; Friedman 2016), and rifampicin, levofloxacin, and clarithromycin (Sugawara 2015).

To date, evaluating the efficacy of treatments for Buruli ulcer has been challenging for several clinical and biological reasons. Firstly, there have been cases in which deterioration was observed during the course of treatment, which are now defined as paradoxical reactions. This phenomenon is now understood to be the result of antibiotic suppression of mycolactone synthesis, leading to the reversal of host immune response toM ulcerans (Nienhuis 2012). Paradoxical reactions may occur at the same site as the initial lesion, or at other sites. When it is at the same site, it is especially difficult to differentiate paradoxical reactions from recurrences; this identification largely influences the clinical decision. The WHO defines recurrences as new and culture-confirmed lesions occurring more than three months after completion of antibiotic treatment (WHO 2012). However, the two conditions cannot be fully differentiated based on this definition alone. Since paradoxical reactions have only recently been documented, some past data on recurrences may have mistakenly included paradoxical reactions. Secondly, microbiological cure and clinical cure are not always the same. In other words, even though M ulcerans was successfully eliminated from the lesion site with antibiotic treatment (microbiological cure), this does not correspond to clinical cure if the patient has already manifested an ulcer. Moreover, in such ulcerated cases, methods used in wound care would also modify the healing process; this is another challenge in correctly evaluating antimicrobial treatment efficacy in people with Buruli ulcer. Selection of wound care methods is often dependent upon daily practice and resource availability. Velding 2014 documented that there was a wide diversity in local wound care methods practiced by health practitioners/healthcare givers in Ghana and Benin. Due to these atypical clinical features and medical practices related to the disease, it has been difficult to develop a clear case definition for cure. Many studies evaluating treatment efficacy in Buruli ulcer disease have used complete epithelialization, Chauty 2007; Sugawara 2015, or reduction in wound size, Etuaful 2005; BURULICO Study 2010; Sugawara 2015, as their definition of cure (clinical cure), while a few studies have also used microbiological cure as their case definition of cure, employing laboratory methods (Etuaful 2005; Sarfo 2010).

\section{How the intervention might work}

As Buruli ulcer is a mycobacterial disease and with growing experience in its management, antibiotic drugs are now an essential part of its treatment (WHO 2012; Yotsu 2015). After the introduction of antibiotic drugs for the treatment of Buruli ulcer by the WHO in 2004, recurrence rates reportedly decreased substantially to $0 \%$ to $2 \%$, and the need for surgical intervention has diminished (Chauty 2007; BURULICO Study 2010; Sarfo 2010). With this simplified treatment and delivery of care, the quality of life of patients has increased not only during treatment, but also after treatment as use of antibiotic drugs has played a role in decreasing the number of those affected by the disease who are left with disabilities and disfigurements (Klis 2014c). In West Africa, where over $40 \%$ of those affected are children under 15 years of age, better treatment further provides better opportunity for education, and thus a better future (Agbenorku 2011; WHO 2012). The use of antibiotic drugs has also decreased the socioeconomic impact on families, as the cost of treatment of surgeries and hospitalization is far beyond the means of those most severely affected (Asiedu 1998; Grietens 2008; Agbenorku 2011).

\section{Why it is important to do this review}

No systematic review of the literature on Buruli ulcer has previously been performed. A review of the efficacy of daily administration of rifampicin and streptomycin in the treatment of early-stage Buruli ulcer including data from 2005 to 2012 was published in 2013 (Vouking 2013). In that review, evidence of diagnostic accuracy and ascertainment of cure was not clear. Also, the review did not include treatment modalities other than rifampicin and streptomycin. In this Cochrane Review, we aimed to assess the effects of antibiotic treatment with or without surgical intervention (debridement, skin grafting, etc.) for people with Buruli ulcer. As the search for more efficacious and/or convenient treatment modalities continues, it was an appropriate time to evaluate and summarize the evidence on current treatment options. 


\section{O B JECTIVES}

To summarize the evidence of drug treatments for treating Buruli ulcer.

\section{ME T HODS}

\section{Criteria for considering studies for this review}

\section{Types of studies}

Randomized controlled clinical trials (RCTs) and prospective observational studies.

\section{Types of participants}

We included participants diagnosed as having Buruli ulcer due to the presence of a suggestive lesion and any one of the following:

- a culture of M ulcerans from the lesion;

- a positive IS2404 dry-reagent-based PCR from a swab or biopsy of the lesion;

- histopathological finding indicative of $M$ ulcerans infection (for example, necrotic granuloma, presence of AFB), irrespective of age.

\section{Types of interventions}

We included studies that compared:

- antibiotic therapy to placebo or alternative therapy such as surgery;

- different antibiotic regimens.

We also included prospective observational studies that evaluated different antibiotic regimens with or without surgery.

\section{Types of outcome measures}

\section{Primary outcomes}

- Cure: healing of skin lesions without recurrence at 12 months or longer.

- Probable cure: healing of skin lesions with follow-up to 12 months.

- Possible cure: healing of skin lesions at follow-up.

\section{Secondary outcomes}

- Surgery.

- Healing time needed for wound closure.

- Reduction in ulcer size.

- Recurrence of skin lesion(s) after healing.

- Adverse effects.

- Paradoxical reactions.

\section{Search methods for identification of studies}

We attempted to identify all potential studies regardless of language or publication status (published, unpublished, in press, and in progress).

\section{Electronic searches}

We searched the following databases using the search terms and strategy described in Appendix 1: the Cochrane Infectious
Diseases Group Specialized Register; the Cochrane Central Register of Controlled Trials (CENTRAL), published in the Cochrane Library (Issue 11, 2017); MEDLINE (PubMed; from 1966); Embase (Ovid; from 1947); and LILACS (Latin American and Caribbean Health Sciences Literature; BIREME) (from 1982). All searches were conducted on 19 December 2017. We also searched the US National Institutes of Health Ongoing Trials Register ClinicalTrials.gov (clinicaltrials.gov) and the World Health Organization (WHO) International Clinical Trials Registry Platform (ICTRP) (www.who.int/ictrp/search/en/) up to 19 December 2017 using "Buruli ulcer" as a search term.

\section{Searching other resources}

We reviewed the reference lists of all included studies. We also contacted leading researchers in this topic area to identify any unpublished data.

\section{Data collection and analysis}

\section{Selection of studies}

Vittoria Lutje, the Cochrane Infectious Diseases Group (CIDG) Information Specialist, searched the literature and retrieved studies using the search strategy outlined in Appendix 1. In the initial stage of selection, two review authors (Rie Roselyne Yotsu (RRY) and Marty Richardson (MR)) independently screened the abstracts of studies retrieved by the search to identify those that met the inclusion criteria. We retrieved the full-text articles of published or unpublished potentially relevant study reports for further assessment. Rie Roselyne Yotsu or Marty Richardson contacted the study authors for further details regarding study methodology if eligibility was unclear. A third review author (Norihisa Ishii (NI)) was consulted when there was a difference of opinion between RRY and MR. If there was still disagreement between the review authors, we consulted one of the CIDG Coordinating Editors to reach a consensus. We examined study reports to ensure that we included multiple publications from the same study only once.

\section{Data extraction and management}

Two review authors (RRY and MR) extracted and summarized data from the included studies on standardized data extraction forms. Any differences of opinion were resolved through discussion. If important data were missing from the included studies, we contacted the study authors for further information.

We extracted the number of participants randomized and the number of participants followed up in each treatment arm, with a list of each study's inclusion and exclusion criteria, a description of the intervention(s), and primary and secondary outcome measures. The data extraction form also included baseline characteristics of participants in the control group such as age, sex, stage of lesions, ulcer size, WHO category, diagnostic results, healing time, side effects, outcome, post-treatment surgery, and recurrence. Rie Roselyne Yotsu entered the data into Review Manager 5 (RevMan 2014).

For dichotomous outcomes, we extracted the number of participants experiencing the event and the number of participants in each treatment group. For continuous outcomes, we extracted arithmetic means, standard deviations, and the numbers of participants for each treatment group. 


\section{Assessment of risk of bias in included studies}

All review authors (RRY, MR, and $\mathrm{NI}$ ) independently assessed the risk of bias for each included study. We assessed RCTs using the Cochrane 'Risk of bias' assessment tool with seven domains of bias including: random sequence generation, allocation concealment, blinding of participants and personnel, blinding of outcome assessment, incomplete outcome data, selective reporting, and other potential sources of bias (Higgins 2011). We assessed prospective observational studies in accordance with methods adopted from 'A Cochrane Risk of Bias Assessment Tool: for NonRandomized Studies of Interventions' (ACROBAT-NRSI) (Sterne 2014). We assessed five domains of bias including: selection of participants into the study, measurement of outcomes, incomplete outcome data, selective reporting, and other potential sources of bias.

We assigned a judgement of either 'high', 'low', or 'unclear' risk of bias for each component. We chose 'unclear' either when the available information was inadequate to judge or when it was neither 'high' nor 'low'. Any discrepancies regarding 'Risk of bias' analysis results were resolved through discussion. We consulted one of the CIDG Co-ordinating Editors if necessary. We presented the findings in a 'Risk of bias' table, and produced figures to summarize the risk of bias across included studies. For domains that did not pertain to the study design, we assigned 'unclear risk of bias' for RCTs and 'low risk of bias' for prospective observational studies so that all studies could be handled in a single 'Risk of bias' graph and summary figure. We also labelled the study name and the domains with the study design in order to enable differentiation between the two study designs.

We further assessed the certainty of the evidence using the GRADE approach for any RCTs for which we could apply this method (Juni 2001). We used GRADEpro GDT software to construct a 'Summary of findings' table (GRADEpro GDT 2015).

\section{Measures of treatment effect}

For RCTs using dichotomous outcomes, we presented the effect of treatment within studies as the risk ratio (RR) with corresponding 95\% confidence interval $(\mathrm{Cl})$.

\section{Unit of analysis issues}

Had we identified studies for inclusion that had multiple intervention arms, we would have included data from these studies by either combining treatment arms, or by splitting the control group so that participants would only be included in the metaanalysis once.

\section{Dealing with missing data}

In the case of missing data, we attempted to contact the study authors to request the missing information. If the study authors did not collect or assess the needed data as part of their study, or if we received no response, we analysed the available data only using a complete-case analysis.

\section{Assessment of heterogeneity}

Had we performed meta-analyses in this review, we would have inspected forest plots visually to assess whether statistical heterogeneity was present. We would have deemed Cls that did not overlap as indicating statistical heterogeneity.

\section{Assessment of reporting biases}

We planned to assess reporting bias by using funnel plots, however we did not create these as we did not perform any meta-analyses in this review.

\section{Data synthesis}

We compared studies in terms of combination of antibiotics and duration, whether adjunctive surgery was performed or not, and lesion size/types in order to determine whether it was possible, and appropriate, to perform meta-analyses. We consequently decided that it was not possible to perform meta-analyses due to the small number of studies with the same intervention, different inclusion criteria (for example, some studies only included small lesions while others included large lesions; some studies only included ulcerated lesions while others included non-ulcerated lesions), and different follow-up/assessment time points. We presented the key characteristics of included studies alongside outcome data in tables, and discussed the results of the included studies narratively.

We will refer to the methods described in the protocol should we need to conduct analyses in future updates.

\section{Subgroup analysis and investigation of heterogeneity}

Had we detected substantial heterogeneity in meta-analyses, we would have explored the possible causes of the heterogeneity by performing subgroup analyses. Subgroups for investigation included lesion sizes, clinical lesions (papule, nodule, plaque, oedema, and ulcer), and surgical intervention.

\section{Sensitivity analysis}

We did not perform sensitivity analyses as we did not perform any meta-analyses in this review.

\section{RES U LTS}

\section{Description of studies}

\section{Results of the search}

We conducted literature searches up to 19 December 2017 and identified 548 titles (Figure 1). While searching for additional information on Arens 2015, we identified one study through its conference proceeding (Beissner 2015), and one study through ongoing trials (Barogui 2016). Two review authors (RRY and MR) closely examined 75 full-text articles. We contacted the technical team at the WHO for possible unpublished studies; there were none other than those we identified. We identified two ongoing trials on US National Institutes of Health Ongoing Trials Register ClinicalTrials.gov (NCT01432925; NCT01659437). 
Figure 1. Study flow diagram.

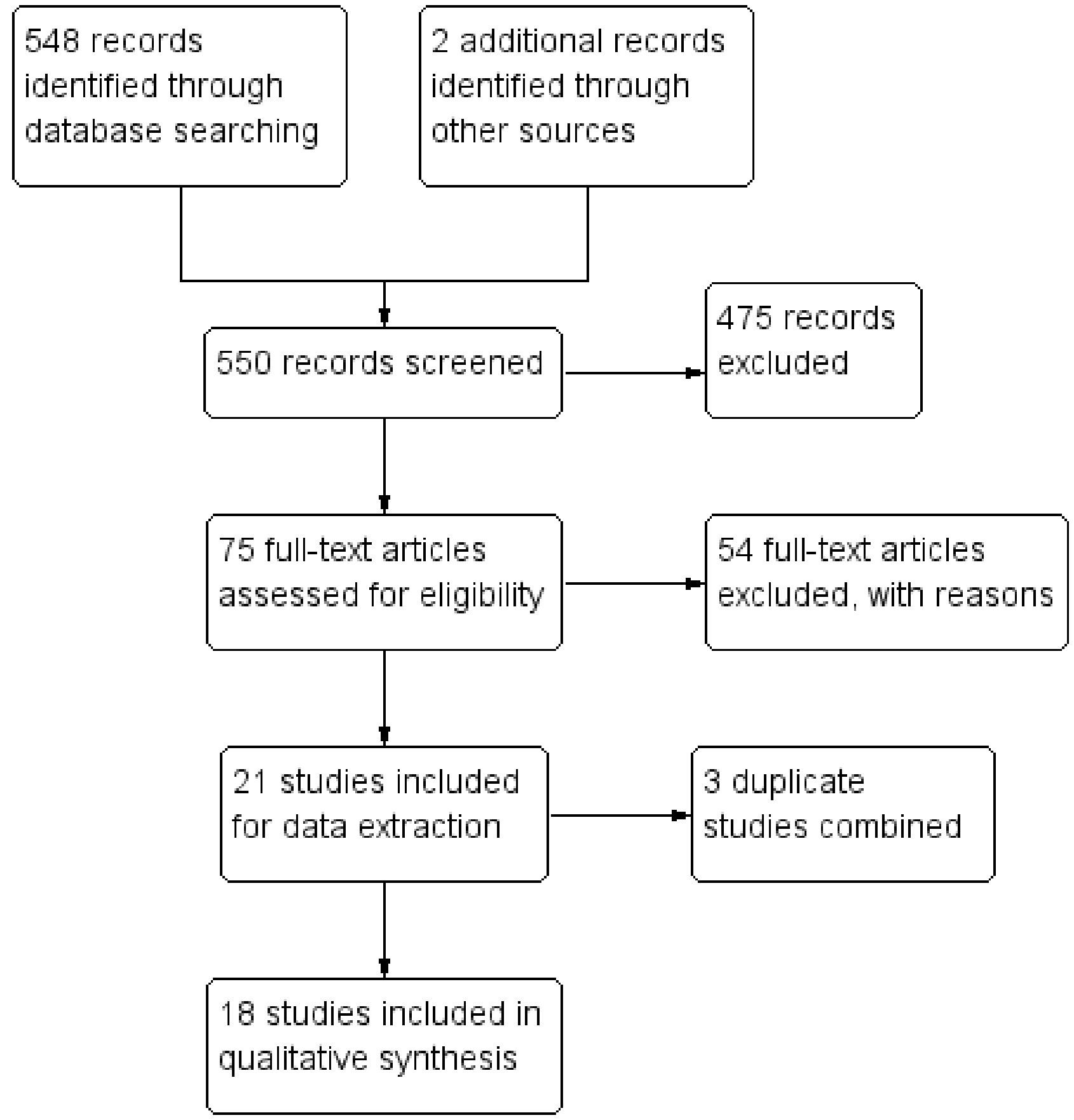

We identified six RCTs and 15 prospective observational studies that met the inclusion criteria. Two review authors (RRY and MR) independently extracted data for these studies.

\section{Included studies}

\section{Study design}

Six articles reported a total of five RCTs. The BURULICO study was reported in two different articles with different outcomes (Nienhuis 2010; Klis 2014; see BURULICO Study 2010).

A total of 15 articles reported prospective observational studies. Five articles were from the same Australian group using the data of Buruli ulcer patients from their registry that they had started collecting in January 1998 (O'Brien 2007; O'Brien 2012; Friedman 2013; O'Brien 2013b; Friedman 2016), and evaluated a number of different combinations of antibiotics. We identified two sets of articles reporting data for the same groups of participants at different time points (Friedman 2013 and Friedman 2016; O'Brien 2007 and O'Brien 2012), therefore we extracted data from only the more recent papers (O'Brien 2012; Friedman 2016). Some participants in O'Brien 2012, O'Brien 2013b, and Friedman 2016 may be included in more than one study, as they were from the same registry. Barogui 2016 combined participants of the BURULICO Study 2010 and the ongoing NCT01432925 trial, 
therefore there is overlap of participants. However, Barogui 2016 measured an outcome (paradoxical reactions) that was not an outcome measure of the original RCTs. We counted this study as an independent, prospective observational study.

We henceforth describe results of the qualitative synthesis of five RCTs and 13 prospective observational studies.

\section{Interventions and comparisons}

\section{Randomized controlled trials}

The included RCTs evaluated the following.

- Monotherapy in comparison to placebo, with surgery when indicated: clofazimine in one trial (Revill 1973), and sulfamethoxazole/trimethoprim in a second trial (Fehr 1994).

- Combination therapy:

- rifampicin + streptomycin before surgery with different lengths of treatment (varying from two to 12 weeks), in comparison to surgery alone (Etuaful 2005);

- rifampicin + streptomycin for four weeks followed by rifampicin + clarithromycin for four weeks in comparison to rifampicin + streptomycin for eight weeks, with surgery when indicated (BURULICO Study 2010);

- rifampicin + dapsone for eight weeks in comparison to no treatment, with no surgery in either arm (Espey 2002).

\section{Prospective observational studies}

Two studies evaluated different treatment regimens in multiple treatment arms (O'Brien 2012; Friedman 2016). All of the other prospective observational studies were single-arm studies. Prospective observational studies evaluated the following.

- Monotherapy with clofazimine for one to four weeks before surgery (Lunn 1964).

- Combination therapy with rifampicin + streptomycin for:

- 12 weeks with surgery at week 4 (Kibadi 2010);

- eight weeks with surgery when indicated (Chauty 2007; Sarfo 2010; Adu 2013; Beissner 2015);

- eight weeks with surgery (Agbenorku 2011).

- Combination therapy with rifampicin + clarithromycin:

- rifampicin + clarithromycin for eight weeks, with surgery when indicated (Chauty 2011);

- rifampicin + streptomycin for two weeks followed by rifampicin + clarithromycin for six weeks, with surgery when indicated (Phillips 2014a).

- Other combination therapy:

o rifampicin + either ciprofloxacin, clarithromycin, or moxifloxacin, with no surgery or with limited debridement (Friedman 2016);

- rifampicin + ciprofloxacin, rifampicin + clarithromycin, rifampicin + clarithromycin + ethambutol, ciprofloxacin + clarithromycin, rifampicin + moxifloxacin, clarithromycin + ethambutol, rifampicin + ethambutol + amikacin, or clarithromycin only, with surgery in all cases, in comparison to surgery alone (O'Brien 2012);

- single or combination administration of rifampicin, ciprofloxacin, clarithromycin, ethambutol, amikacin, and/or moxifloxacin, with surgery when indicated (O'Brien 2013b);
- either rifampicin + streptomycin for eight weeks or rifampicin + streptomycin for four weeks followed by rifampicin + clarithromycin for four weeks, with surgery when indicated (Barogui 2016).

\section{Location and participants}

All studies were conducted in areas with high Buruli ulcer endemicity: of the RCTs, three were conducted in Ghana and one in Côte d'Ivoire and in Uganda; of the prospective observational studies, four were conducted in Ghana, three in Australia, two in Benin, one in Uganda, one in Democratic Republic of Congo, and one in Togo. Barogui 2016 was a joint study between Ghana and Benin.

Some studies set inclusion criteria for age and lesion type or size given in diameter. Of the RCTs, the BURULICO Study 2010 recruited participants over five years with lesion size less than $10 \mathrm{~cm}$; Etuaful 2005 recruited participants over 15 years with lesion size less than $10 \mathrm{~cm}$; and Espey 2002 recruited participants over four years with ulcers. Of the prospective observational studies, Chauty 2011 recruited participants over five years with lesion size less than 10 cm; Phillips 2014a recruited participants over five years with lesion size less than $15 \mathrm{~cm}$; Kibadi 2010 recruited participants between three and 75 years with lesion size larger than $10 \mathrm{~cm}$; and the NCT01432925 trial (a part of Barogui 2016) recruited participants over three years of age. All other included studies recruited all age groups and lesion sizes.

Three RCTs, Fehr 1994; Etuaful 2005; BURULICO Study 2010, and 10 prospective observational studies, Sarfo 2010; Agbenorku 2011; Chauty 2011; O'Brien 2012; Adu 2013; O'Brien 2013b; Phillips 2014a; Beissner 2015; Barogui 2016; Friedman 2016, had laboratory confirmation as part of their inclusion criteria. The remaining included studies did not have laboratory confirmation as an inclusion criterion.

\section{Outcomes and length of follow-up}

Outcomes in the RCTs varied. One trial measured "cure" (BURULICO Study 2010), and one trial measured "possible cure" (Revill 1973). Both trials also measured healing time (Revill 1973; BURULICO Study 2010). Otherwise, change in ulcer size was investigated in three trials (Fehr 1994; Espey 2002; Etuaful 2005), recurrence in three trials (Revill 1973; Etuaful 2005; BURULICO Study 2010), and adverse effects in three trials (Espey 2002; Etuaful 2005; BURULICO Study 2010).

Of the prospective observational studies, seven studies measured "cure" (Phillips 2004; Kibadi 2010; Sarfo 2010; Agbenorku 2011; Chauty 2011; O'Brien 2012; Friedman 2016); one study measured "probable cure" (Chauty 2007); and three studies measured "possible cure" (Lunn 1964; Adu 2013; Beissner 2015). Healing time was investigated in five studies (Sarfo 2010; Chauty 2011; Phillips 2014a; Beissner 2015; Friedman 2016), change in ulcer size in one (Sarfo 2010), recurrence in eight (Chauty 2007; Kibadi 2010; Sarfo 2010; Agbenorku 2011; Chauty 2011; O'Brien 2012; Phillips 2014a; Beissner 2015), adverse effects in eight (Lunn 1964; Chauty 2007; Sarfo 2010; Agbenorku 2011; Chauty 2011; O'Brien 2012; Phillips 2014a; Friedman 2016), and paradoxical reactions in six studies (Sarfo 2010; O'Brien 2012; O'Brien 2013b; Phillips 2014a; Barogui 2016; Friedman 2016). 
Follow-up period varied in the RCTs. Etuaful 2005 followed up participants until one year after completion of treatment. In the BURULICO Study 2010, Nienhuis and colleagues first followed up participants until one year, and then Klis and colleagues revisited participants again during four to six years after treatment. Two trials did not specify their follow-up time (Fehr 1994; Espey 2002). In the earlier study by Revill 1973, their follow-up period ranged from 17 to 40 months, with a median of 32 months. Follow-up in the prospective observational studies was one year in six studies (Chauty 2007; Sarfo 2010; O'Brien 2012; O'Brien 2013b; Phillips 2014a; Friedman 2016). Otherwise, it was seven months in Barogui 2016, 1.5 years in Chauty 2011, two years in Agbenorku 2011 and Kibadi 2010, and not specified in Lunn 1964, Adu 2013, and Beissner 2015.

\section{Excluded studies}

We excluded 475 studies after title and abstract screening. We assessed 75 full-text articles for eligibility, of which we excluded 37 on the basis of their study design (retrospective observational studies, cross-sectional surveys, case series, or qualitative studies), eight because they were either reviews or commentaries, five because they were conference proceedings, and four because they were duplicates.

\section{Risk of bias in included studies}

We have summarized the risk of bias in included studies in Figure 2 and Figure 3.

\section{Figure 2. 'Risk of bias' graph: review authors' judgements about each risk of bias item presented as percentages} across all included studies.

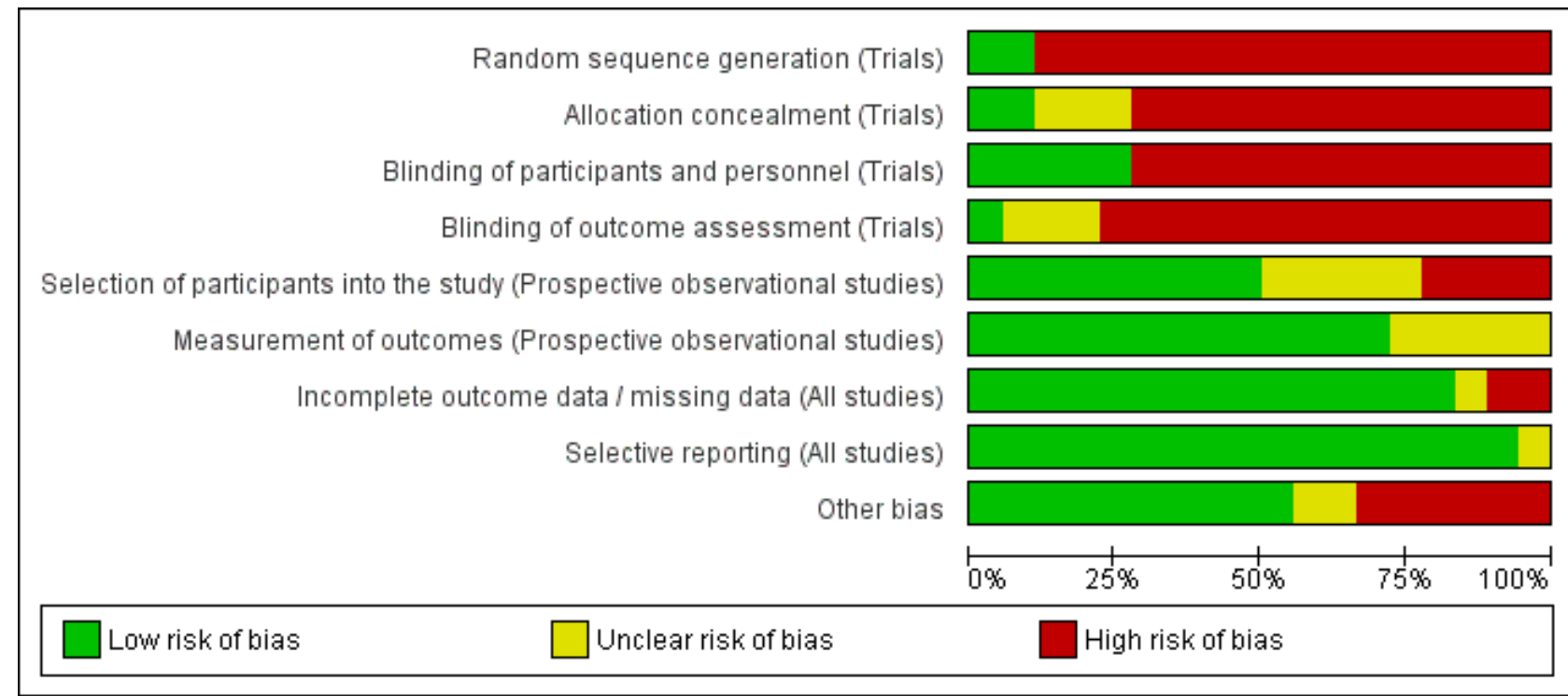


Figure 3. 'Risk of bias' summary: review authors' judgements about each risk of bias item for each included study.

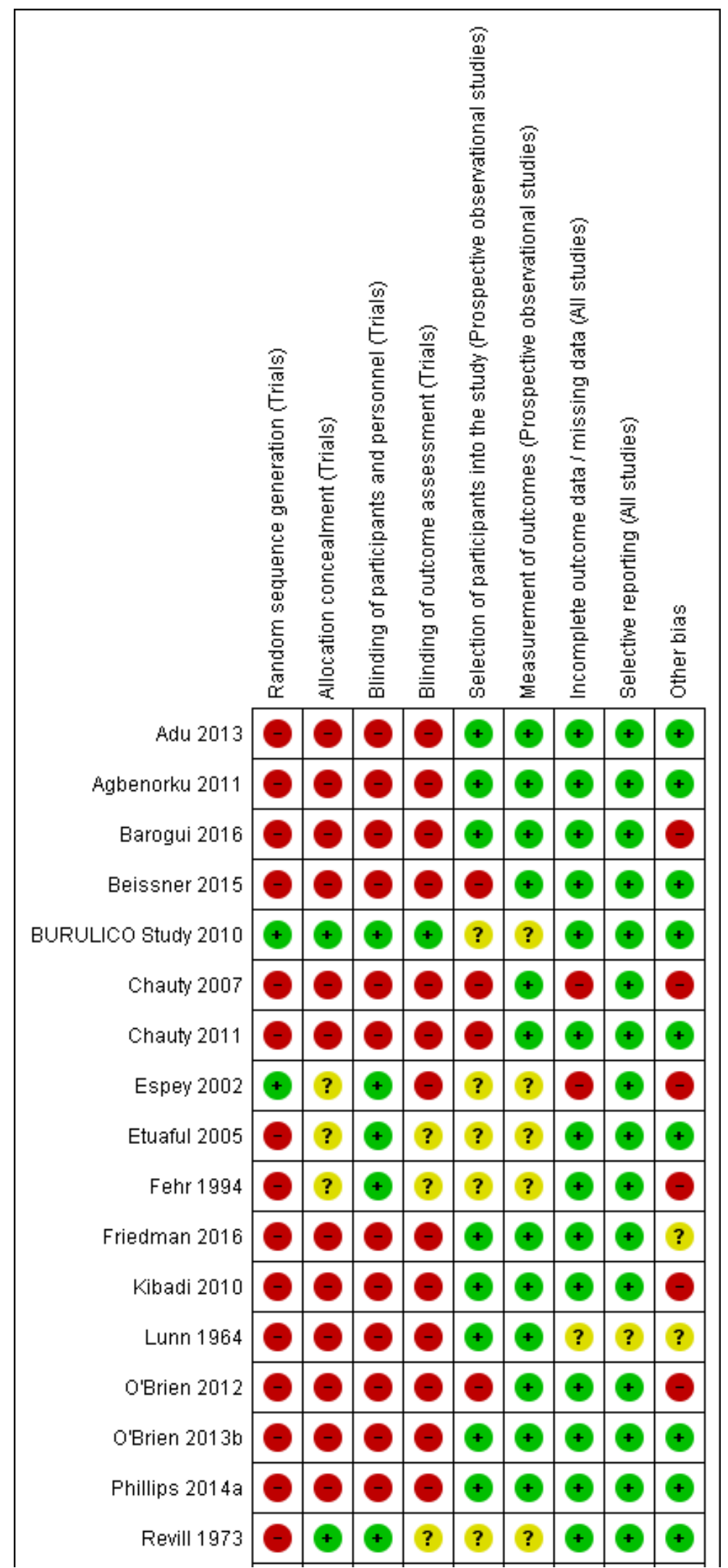

Drugs for treating Buruli ulcer (Mycobacterium ulcerans disease) (Review) 
Figure 3. (Continued)

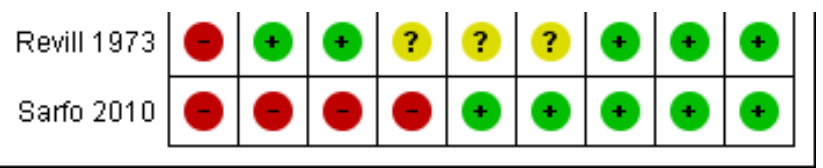

\section{Randomized controlled trials}

Of the five included RCTs, only BURULICO Study 2010 used adequate methods. Otherwise, either methods were either inadequate or details were poorly reported in the remaining studies.

\section{Prospective observational studies}

Of the 13 prospective observational studies, we rated seven recent studies as at low risk of bias (Sarfo 2010; Agbenorku 2011; Adu 2013; O'Brien 2013b; Phillips 2014a; Barogui 2016; Friedman 2016). The older studies were associated with a higher risk of bias (Lunn 1964; Chauty 2007).

\section{Allocation}

Of the five RCTs, two were blinded and were rated as at low risk of bias (Revill 1973; BURULICO Study 2010). Otherwise, no information, Espey 2002; Etuaful 2005, or no clear statement, Fehr 1994, was provided, and these studies were rated as at unclear risk of bias.

\section{Blinding}

Of the five RCTs, two were blinded and were rated as at low risk of bias (Revill 1973; Fehr 1994). Otherwise, the RCTs were openlabel, BURULICO Study 2010, or no clear statement was provided, Espey 2002; Etuaful 2005, but were rated as at low risk of bias as the outcome was unlikely to be influenced by lack of blinding.

\section{Incomplete outcome data}

Of the five RCTs, we rated one as at high risk of bias, as 10 out of 30 participants (33\%) were lost to follow-up (Espey 2002). The proportion of missing data was relatively large in one RCT (6/18 participants, 33\%) (Fehr 1994), however reasons for exclusions/ missing data were relatively well balanced or unlikely to be related to true outcome, and the RCT was rated as at low risk of bias. Otherwise, no participants, Etuaful 2005, or a minimal number of participants, Revill 1973; BURULICO Study 2010, were lost to followup, and we judged these RCTs as at low risk of bias.

Of the 13 prospective observational studies, we rated two studies as at high risk of bias: the assessment time point was unclear in Lunn 1964, and 17 participants were lost to follow-up during the study period but were included in the final analysis in Chauty 2007. Otherwise, either no participants, Kibadi 2010; Agbenorku 2011; Chauty 2011; O'Brien 2012; Adu 2013; O'Brien 2013b; Beissner 2015; Barogui 2016; Friedman 2016, or a minimal number of participants, Sarfo 2010; Phillips 2014a, were lost to follow-up, and we considered these studies as at low risk of bias.

\section{Selective reporting}

Of the five included RCTs, we rated one as at unclear risk of bias as there were no predefined outcomes (Lunn 1964). All of the other RCTs reported all expected outcomes, and we rated these as at low risk of bias.
All 13 prospective observational studies reported all expected outcomes and were rated as at low risk of bias.

\section{Other potential sources of bias}

Five studies either did not have laboratory confirmation as their inclusion criteria or only performed laboratory exams in a portion of their participants, therefore non-Buruli ulcer cases may be included in their study results (Lunn 1964; Revill 1973; Espey 2002; Chauty 2007; Kibadi 2010). The standard treatment for Buruli ulcer has transitioned from surgery to drugs plus surgery as adjunctive treatment after the recommendation of drug treatment by the WHO in 2004 (WHO 2014), and this may have created some bias.

Potential comorbidities such as osteomyelitis, HIV/AIDS, diabetes mellitus, cancer, and use of immunosuppressant drugs may have affected some results, especially on severity and healing rate and time. Two studies reported on comorbidities of their study participants: 9.5\% in Friedman 2016 and 16.3\% in O'Brien 2012; there may be an overlap of participants in these two studies.

\section{Effects of interventions}

See: Summary of findings for the main comparison Rifampicin combined with streptomycin compared with surgery alone for Buruli ulcer; Summary of findings 2 Rifampicin with clarithromycin compared with rifampicin with streptomycin in the consolidation phase for Buruli ulcer

We first assess the effects of a variety of treatments on healing and recurrence, stratified by monotherapy and combination therapy. We then summarise adverse effects and paradoxical reactions across all comparisons.

\section{Healing and recurrence}

\section{Monotherapy}

See Table 1.

One RCT and one prospective observational study evaluated the efficacy of clofazimine, and one RCT evaluated the efficacy of sulfamethoxazole/trimethoprim. All three studies had small sample sizes, and no treatment effects were demonstrated.

\section{Clofazimine}

Revill 1973 compared clofazimine to placebo, with similar recurrence in the two arms (clofazimine 8/51 (15.7\%); placebo 10/54 (18.5\%); difference $2.8 \%$, 95\% confidence interval (Cl) not given). The authors examined a subgroup of participants with nonulcerated lesions who were withheld from immediate surgery: the number that healed was slightly higher with clofazimine, but the difference was small, and this was a post hoc subgroup analysis (clofazimine, 5/13 (38\%); placebo, 6/21 (29\%)). The median healing time was measured in this same subgroup also those with a lesion less than $5 \mathrm{~cm}$ in diameter (clofazimine, 8 participants; placebo, 17 participants) and was 21 weeks and 14 weeks, respectively. 
One prospective observational study, Lunn 1964, examined the effects of clofazimine with surgery in 10 participants with ulcers. Six participants (60\%) achieved complete healing in 3 to 12 weeks. The remaining four participants were still under treatment for their ulcers at the time of reporting.

\section{Sulfamethoxazole/trimethoprim}

Fehr 1994 compared sulfamethoxazole/trimethoprim to placebo in 12 participants with ulcers. The mean ulcer size in the sulfamethoxazole/trimethoprim group at baseline was $73.8 \mathrm{~cm}^{2}(9$ to 247 ) and in the placebo group was $38.7 \mathrm{~cm}^{2}$ (15 to 80 ). The authors reported that sulfamethoxazole/trimethoprim reduced ulcer size by an average of $10.9 \%$, while an average increase of $24.5 \%$ was observed in the placebo group $(P=0.15)$. The percentage ulcer area covered by granulation tissue at study end was $92 \%$ in the sulfamethoxazole/trimethoprim group and $57 \%$ in the placebo group $(P=0.17)$.

\section{Combination therapy}

Rifampicin combined with streptomycin

See Table 2.
One RCT and six prospective observational studies investigated the efficacy of rifampicin and streptomycin. Five prospective observational studies evaluated this regimen administered for 8 weeks ( 828 participants) with surgery given to either all participants or a select group. Four studies reported healing rates for all participants, regardless of whether they had received surgery or not ( $84.5 \%$ to $100 \%$, assessed at various time points). Four studies reported healing rates for participants who received combination therapy alone (48\% to $95 \%$, assessed at various time points).

One RCT, Etuaful 2005, examined 21 participants with nonulcerative lesions to test the efficacy of rifampicin and streptomycin. They divided the participants into 5 groups: 4 groups were given rifampicin and streptomycin for 2, 4, 8, and 12 weeks before surgery respectively, and one group received only surgery. No recurrence was observed in participants in any group receiving combination therapy at 12 months, compared with one case of recurrence in a participant who received only surgery. No difference in recurrence was observed between these two groups (risk ratio (RR) $0.12,95 \% \mathrm{Cl} 0.01$ to 2.51; Figure 4; Analysis 1.1). Reduction in lesion surface area in participants who received rifampicin and streptomycin was the highest (52\%) in the group that underwent four weeks of the regimen before surgery.

\section{Figure 4. Forest plot of comparison: 1 Rifampicin plus streptomycin (experimental) versus surgery alone (control),} outcome: 1.1 Recurrence.

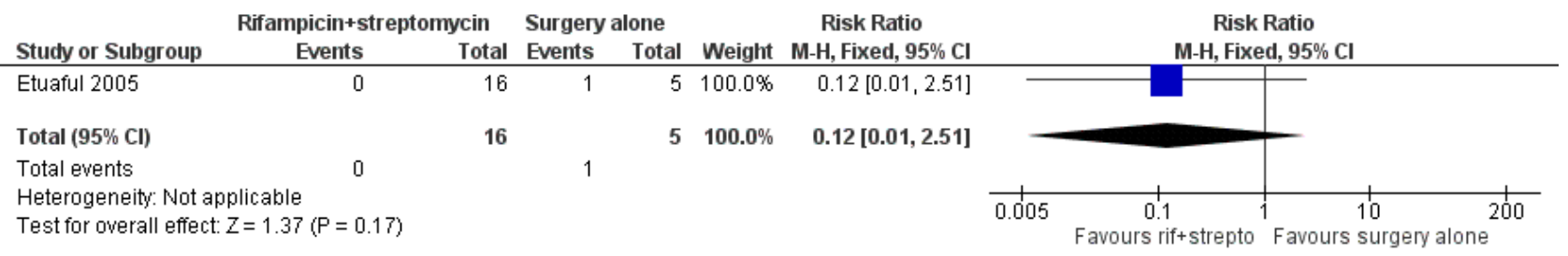

One prospective observational study, Kibadi 2010, examined rifampicin and streptomycin given for 12 weeks with surgery performed at week 4, in 92 participants with ulcerative lesions measuring more than $10 \mathrm{~cm}$ in diameter. The study showed a high healing rate at week $12(85 / 92,92.4 \%)$ and low recurrence rate at 2 years $(2 / 92,2.2 \%)$.

Five prospective observational studies examined treatment with rifampicin and streptomycin for eight weeks (Chauty 2007; Sarfo 2010; Agbenorku 2011; Adu 2013; Beissner 2015). In one study all participants received surgery either during or after treatment (in this study surgery included debridement and skin grafting, not just excision) (Agbenorku 2011); in one study a select group received surgery after assessment at week 4 and week 8 (Chauty 2007); and in three studies a select group of participants received after eight weeks of treatment (Sarfo 2010; Adu 2013; Beissner 2015).

- Where surgery was given to a select group participants, surgery rate differed among studies: 5\% in Sarfo 2010, 27\% in Beissner 2015, 52\% in Chauty 2007, and 52\% in Adu 2013.

- Four studies reported healing rates for all participants, regardless of whether they received surgery or not: $84.5 \%$ in Beissner 2015, 96.3\% in Agbenorku 2011, 99.3\% in Sarfo 2010 and $100 \%$ in Chauty 2007.

- Four studies reported healing rates for participants who received combination therapy alone: $48 \%$ at week 8 in Adu 2013, 48\% after week 8 in Chauty 2007, 69.8\% after minimum of 6 months follow-up in Beissner 2015, and 95\% at 12 months in Sarfo 2010.

- Follow-up showed recurrence was unusual: 0\% in Sarfo 2010 and Beissner 2015, 0.5\% in Agbenorku 2011, and 1.4\% in Chauty 2007.

\section{Rifampicin combined with clarithromycin}

See Table 3.

Two prospective observational studies (51 participants) evaluated the use of rifampicin and clarithromycin. Both studies included surgery, either to all participants or a select group. All participants were healed at 12 months.

Chauty 2011 evaluated rifampicin and clarithromycin for eight weeks in 30 participants with lesions measuring less than $10 \mathrm{~cm}$ in diameter. They reported a high healing rate at 12 months with no recurrence at 18 months $(30 / 30,100 \%)$. Half of the participants $(50 \%)$ healed without any form of surgery; 11 participants $(37 \%)$ healed with limited surgery including curettage of the lesion or a minor excision; and 4 participants (13\%) healed with extensive surgery including major excision followed by skin grafting.

O'Brien 2012 evaluated rifampicin and clarithromycin with surgery in 21 participants and reported a high healing rate $(100 \%)$ and no recurrence at one year. Duration of the regimen was determined by the attending physician. 
Rifampicin with streptomycin initially, changing to rifampicin with clarithromycin in consolidation phase

See Table 3.

One RCT and one prospective observational study examined healing rates starting with rifampicin and streptomycin, and then swapping to rifampicin and clarithromycin, with surgery as indicated. Both studies only included participants with small lesions, and more than $90 \%$ of participants healed without surgery.

One RCT, BURULICO Study 2010, evaluated a regimen of rifampicin plus streptomycin for 4 weeks followed by rifampicin plus clarithromycin for 4 weeks in 151 participants with lesions measuring less than $10 \mathrm{~cm}$ in diameter. They compared this to the standard treatment at the time of eight weeks of rifampicin and streptomycin. Both groups achieved high healing rates at 12 months without surgery (a small number in each group had skin grafting): new regimen 68/75 (91\%), standard regimen $73 / 76$ (96\%). There was no significant difference in healing rate or recurrence between the two groups (RR 0.94, 95\% Cl 0.87 to 1.03; not estimable due to 0 cases in both groups; Figure 5, Analysis 2.1; Figure 6; Analysis 2.2) or in healing time.

Figure 5. Forest plot of comparison: 2 Rifampicin combined with clarithromycin versus rifampicin combined with streptomycin in the consolidation phase, outcome: 2.1 Cure.

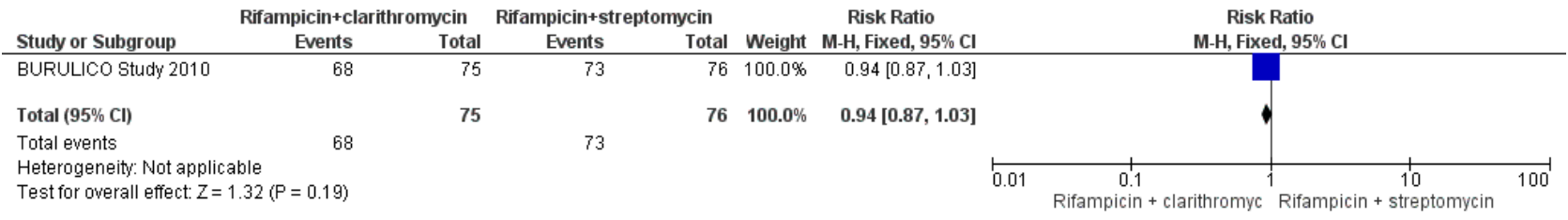

Figure 6. Forest plot of comparison: 2 Rifampicin plus clarithromycin (experimental) versus rifampicin plus streptomycin in the consolidation phase (control), outcome: 2.2 Recurrence at 12 months.

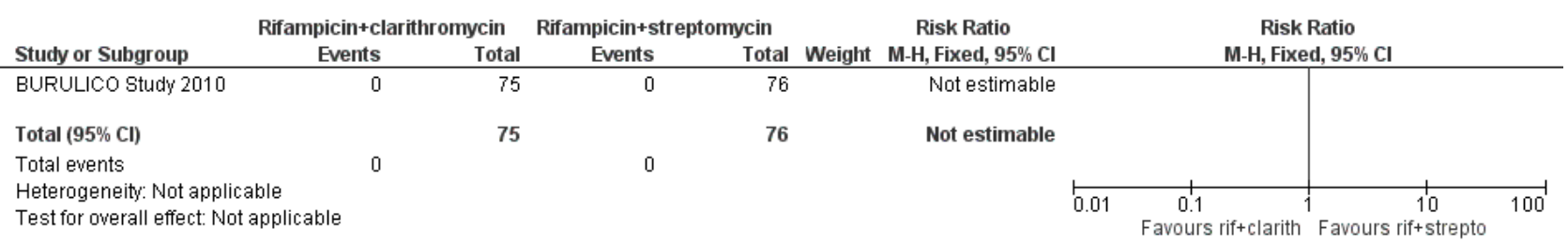

One prospective observational study, Phillips 2014a, evaluated a regimen of rifampicin plus streptomycin for 2 weeks followed by rifampicin plus clarithromycin for 6 weeks in 43 participants with lesions measuring less than $15 \mathrm{~cm}$ in diameter. Forty of $41(98 \%)$ participants achieved healing by 52 weeks without surgery.

\section{Novel combination therapy}

See Table 4.

One RCT and two prospective observational studies investigated the efficacy of combinations of one to three drugs from the following: rifampicin, dapsone, ciprofloxacin, clarithromycin, moxifloxacin, ethambutol, amikacin, and azithromycin. High healing rates and low recurrence were achieved in the two prospective observational studies.

One RCT, Espey 2002, examined the efficacy of rifampicin and dapsone for 8 weeks against placebo in 30 participants with ulcerative lesions. No significant differences were observed for clinical improvement as judged by Buruli ulcer specialists using photographs $(P=0.51)$. A significant change in ulcer size after two months was observed $(P=0.02)$, however there was a significant difference in the initial ulcer size between the two groups.

Two prospective observational studies from the Australian group tested combinations of one to three oral antibiotics including rifampicin, ciprofloxacin, clarithromycin, moxifloxacin, ethambutol, amikacin, and azithromycin. Friedman 2016 evaluated participants who received the regimen with no surgery or with limited surgical debridement. Among the 160 participants in their registry, 28 participants (17.5\%) who received extensive surgery were excluded, leaving 132 participants for their analysis. They reported that 131/132 (99\%) participants healed at one year, among whom 101 (76.5\%) participants healed with antibiotics alone. Median duration of antibiotic treatment was 56 days (interquartile range 24 to 96 days), and 22 participants (16.7\%) needed fewer than 56 days to reach healing. O'Brien 2012 compared participants who were treated with antibiotics plus surgery to surgery alone. All $90 / 90$ participants $(100 \%)$ who underwent combined treatment with antibiotics plus surgery healed. Fourteen (30\%) participants who received only surgery had recurrence. As the participants were retrieved from the same registry in these two studies, some participants may contribute data to more than one of the studies.

\section{Adverse effects}

Three RCTs evaluated adverse effects, of which two reported none (Espey 2002; Etuaful 2005). One RCT evaluated long-term adverse effects of streptomycin three to six years after treatment (BURULICO Study 2010). Among those that could be retrieved from the past BURULICO study ( $n=127$ ), ototoxicity was observed in $23 \%$ of adults in the 4-week streptomycin group and $40 \%$ of adults in the 8 -week streptomycin group (total $n=41$ ), and in $28 \%$ of children in the 4 -week streptomycin group and $26 \%$ of children in the 8 -week 
streptomycin group (total $n=86$ ). Nephrotoxicity during treatment was observed in $9 \%$ of adults in the 4-week streptomycin group and $20 \%$ of adults in the 8 -week streptomycin group, and in $5 \%$ of children in the 4-week streptomycin group and $20 \%$ of children in the 8-week streptomycin group. At long-term follow-up, one adult $(2.4 \%)$ and two children (2.4\%) were classified as having long-term nephrotoxicity, all from the 8-week streptomycin group.

Eight prospective observational studies evaluated adverse effects, of which two reported none (Chauty 2007 (rifampicin, streptomycin) and Agbenorku 2011 (rifampicin, streptomycin)). One study reported no discontinuation of antibiotics (rifampicin, clarithromycin) due to adverse effects (Chauty 2011). Lunn 1964 reported one participant with gastrointestinal intolerance from clofazimine. Sarfo 2010 reported one participant with dizziness and one with vomiting and dizziness from streptomycin, and one participant with rash probably from rifampicin. Phillips 2014a reported one participant with ototoxicity from streptomycin. O'Brien 2012 reported that of 90 participants who received antibiotic treatment, $28(31 \%)$ developed adverse effects including gastrointestinal intolerance, hepatitis, rash, hypoglycaemia, joint or tendon effects, palpitations, and hallucinations. Friedman 2016 reported that 21 of the 132 participants (16\%) developed adverse effects (unspecified) that required cessation of one or more antibiotics during treatment.

\section{Paradoxical reactions}

See Table 5.

Six prospective observational studies evaluated paradoxical reactions (Sarfo 2010; O'Brien 2012; O'Brien 2013b; Phillips 2014a; Barogui 2016; Friedman 2016), of which two studies evaluated solely this outcome (O'Brien 2013b; Barogui 2016).

The incidence of paradoxical reactions ranged from 1.9\% in Sarfo 2010 to $26 \%$ in Friedman 2016. Median onset time of paradoxical reactions ranged from 5.6 weeks (39 days) in O'Brien 2013b to 12 weeks in Phillips 2014a. As the participants were retrieved from the same registry in three studies (O'Brien 2012; O'Brien 2013b; Friedman 2016), some participants may contribute data to more than one of the studies.

\section{DISCUSSION}

\section{Summary of main results}

See Summary of findings for the main comparison and Summary of findings 2.

We included 18 studies, of which five were RCTs, in this review. Earlier studies conducted before 2000 that assessed monotherapy (clofazimine, sulfamethoxazole/trimethoprim) demonstrated no treatment effect. The remaining studies assessed combination therapy with or without surgery. The main regimens included rifampicin plus streptomycin, rifampicin plus clarithromycin, and rifampicin plus streptomycin switching to rifampicin plus clarithromycin during the consolidation phase.

It is evident that antimicrobials are important in treating Buruli ulcers; this was an already established fact, but also learned from this review. Different combinations of antibiotics are given for eight weeks to treat Buruli ulcer, irrespective of the stage. However, there were insufficient studies and data to be able to determine which regimen is the most effective. In 2004, the WHO first recommended a combination of rifampicin and streptomycin for eight weeks (WHO 2014). However, there is no evidence from RCTs to support this treatment. Five prospective observational studies tested this regimen, which reported healing rates from $84.5 \%$ to $100 \%$ with or without surgery. Four studies reported healing rates for participants who received combination therapy alone to be from $48 \%$ to $95 \%$. The time points assessed in the studies varied, and therefore a comparison or calculation of a combined healing rate was not possible.

There has recently been movement from the current regimen, which requires injection, to an all-oral treatment, with the goal of reducing the burden of treatment for patients. Of the studies included in this review, BURULICO Study 2010 was the only RCT with adequate methods. This study tested rifampicin plus streptomycin for four weeks followed by rifampicin and clarithromycin for four weeks against rifampicin plus streptomycin for eight weeks, so that the patients will receive fewer injections of streptomycin. The study showed that there was no significant difference in healing rate and time between the two regimens. Other studies have investigated different combinations of oral drugs, with most regimens yielding high healing rates (Chauty 2011; O'Brien 2012; Friedman 2016). The study sample sizes were small, and their study design was weak to examine the effects of these regimens, however these studies show the potential of all-oral treatments. The WHO currently lists use of rifampicin (10 $\mathrm{mg} / \mathrm{kg}$ once daily) with either streptomycin ( $15 \mathrm{mg} / \mathrm{kg}$ once daily) or clarithromycin $(7.5 \mathrm{mg} / \mathrm{kg}$ twice daily) for eight weeks as the treatment choices for Buruli ulcer, depending on the patient (WHO 2012; WHO 2017).

When assessing the efficacy of treatments for Buruli ulcers, lesion size, lesion type, and whether surgery was applied or not are important factors to be considered. We attempted to perform a subanalysis, but this was not possible due to the heterogeneity of studies. It may also be important to consider the impact of the severity of lesions (WHO category) on treatment efficacy, however not all studies reported these data. It is important to note that some studies that reported high healing rates recruited only participants with small lesions, which may be important to consider when interpreting the results from these studies (Etuaful 2005; BURULICO Study 2010; Chauty 2011; Phillips 2014a).

Six prospective observational studies measured incidence of paradoxical reactions, which ranged from $1.9 \%$ to $26 \%$. The pathogenesis of paradoxical reactions remains unclear, but recent studies report a possible association with antibiotic treatment and types of antibiotics used (O'Brien 2009; Nienhuis 2012; O'Brien 2013b).

\section{Overall completeness and applicability of evidence}

All studies included both males and females. With regards to age, participants from African countries were younger compared to those from Australia, which could have influenced the results. This is reflected by the different age distributions of the affected population between the two areas (Asiedu 1998; Wansbrough-Jones 2006; Boyd 2012). Comorbidities (including HIV) in participants were uncommon, or those with comorbidities were excluded from the study, with the exception of the Australia group studies. Rates of comorbidities in the two Australian studies $(9.5 \%$ and $16.3 \%)$ could have affected their study results. 
Five studies (26\%) diagnosed Buruli ulcer based only on clinical presentation, otherwise all studies had laboratory confirmation of Buruli ulcer either by Ziehl-Neelsen test for AFB, polymerase chain reaction (PCR), or histopathology. All recent studies (after 2007) had laboratory confirmation of Buruli ulcer as part of their inclusion criteria.

Treatment was often given for eight weeks, which has been the WHO recommendation since 2004, and different durations were not tested. Dosages of the drugs were the same between studies: $10 \mathrm{mg} / \mathrm{kg} /$ day for rifampicin, $15 \mathrm{mg} / \mathrm{kg} /$ day for streptomycin, and $7.5 \mathrm{mg} / \mathrm{kg} /$ day for clarithromycin. Intervention with surgery made it a challenge to compare the outcomes between studies. However, it is an important adjunctive intervention to drugs for treating Buruli ulcer, and participants who received surgery were included in the study results. The extent/definition of surgical intervention differed between studies: for example, skin grafting was not considered to be surgery in BURULICO Study 2010 and Friedman 2016. Furthermore, the decision of when to intervene with surgery differs among surgeons/clinicians, and this may have affected the results. It is also important to note that earlier studies tended to perform surgery more often than current studies, as it used to be the standard treatment.

Healing as defined by complete epithelialization was the primary outcome in most studies, but not in the earlier studies, where it was change in ulcer size (Fehr 1994; Espey 2002; Etuaful 2005). The only other outcome that was comparable between studies was recurrence. Assessment time points differed between studies, which made it impossible to compare or synthesize the results from different studies.

\section{Certainty of the evidence}

The certainty of the evidence was very low.

\section{Potential biases in the review process}

We attempted to limit bias in the review process. Vittoria Lutje, the Cochrane Infectious Diseases Group Information Specialist, conducted the literature searches, and it is unlikely that these searches missed any major studies; however, we cannot rule out the possibility that we missed some small unpublished studies.

We included prospective observational studies in this review as there was a very limited number of RCTs investigating this topic. This decision was made after a number of discussions between the authors, the Cochrane Infectious Diseases Group, and their reviewers. While this may have created some bias in this review, we have tried to minimize bias by reporting the results of prospective observational studies separately from RCTs.

To limit bias in the study selection process and data extraction, we independently examined the search results, selected studies, and extracted data.

\section{Agreements and disagreements with other studies or reviews}

There were no other studies or reviews with which to compare this review.

\section{AUTHORS' CONCLUSIONS}

\section{Implications for practice}

People with Buruli ulcers should receive drug therapy. This is obvious and not the subject of this Cochrane Review.

Regarding choice of drug and duration of treatment, the studies included in this review did not provide substantive evidence to guide recommendations. The differences in efficacy between drugs is still uncertain, although the included studies at low risk of bias did demonstrate a high healing rate of Buruli ulcer lesion(s) with the use of combined drug therapy, with or without surgery. How different sizes/lesions/stages of the disease may contribute to healing and which kind of lesions are in need of surgery were unclear from the included studies. These factors need to be considered, as does the practicality of the treatment in resourcelimited settings where most people with Buruli ulcer reside, when guiding recommendations for the treatment of Buruli ulcer.

The current available evidence does not support the use of rifampicin and streptomycin for an eight-week duration, which has been the standard regimen used in endemic African countries.

\section{Implications for research}

There were two ongoing trials at the time of publication of this Cochrane Review. One trial is a multicentre study between Ghana and Benin testing rifampicin and clarithromycin for eight weeks (NCT01659437). The other trial is testing the timing of surgery with rifampicin and streptomycin for eight weeks (NCT01432925). The preliminary results of these studies were reported at the World Health Organization Buruli Ulcer Meeting in March 2017 and will be included in our updated review.

Conducting field trials to test treatment effect of Buruli ulcer is complex and challenging, as:

- there are a limited number of patients (2000 to 5000 annual cases globally); and

- there are multiple treatments that contribute to healing including surgery and wound care and not just drugs.

Although we assessed the certainty of the evidence of the studies included in this review as low, researchers have worked hard to generate this body of evidence under these circumstances.

Further research will be useful testing different regimens, including the possibility of new drugs/combinations; different durations of treatment depending on the lesion stage; and timing of surgical interventions. Antituberculosis drugs that arrived recently on the market could also be useful in the treatment of Buruli ulcer and need to be tested, yet the high cost of these drugs is a concern for use in resource-limited settings, where most patients reside. Cost analysis of treatment - which is often neglected and needs more attention - is therefore also an important area for investigation. As Buruli ulcer is a toxic disease while it is an infection, antitoxins or other systemic drugs may bring about a breakthrough in the treatment of the disease and are interesting areas for exploration. The development of reliable and low-cost point-of-care diagnostic tools are needed to promote a better body of evidence for Buruli ulcer treatment. The primary diagnostics to confirm the disease is currently polymerase chain reaction (PCR), which is not readily available in many endemic areas. Assessment time points of 
healing and recurrence should be made uniform so as to allow comparison between studies, and such action should be initiated. This can be facilitated by the development of tools to quantify healing. For example, level of mycolactone in lesions, blood, or urine could be a candidate for this purpose in the future when quantitative test of mycolactone will be made easier to use. Wound care is another essential focus for research in Buruli ulcer, which may also benefit other diseases with ulcers. Operational research in order to detect, diagnose, and treat patients early also needs to be promoted.

\section{ACKNOWLEDGEMENTS}

Marty Richardson is supported by the Research, Evidence and Development Initiative (READ-It) project. The READ-It project and the editorial base of the Cochrane Infectious Diseases Group are funded by UK aid from the UK government for the benefit of lowand middle-income countries (project number 300342-104). The views expressed do not necessarily reflect the UK government's official policies. 


\section{R E F E R E N C E S}

\section{References to studies included in this review}

Adu 2013 \{published data only\}

Adu EJ. Management of complications of Mycobacterium ulcerans disease: a three-year review. International Journal of Mycobacteriology 2013;2(4):206-10.

\section{Agbenorku 2011 \{published data only\}}

Agbenorku P, Agbenorku M, Amankwa A, Tuuli L, Saunderson P. Factors enhancing the control of Buruli ulcer in the Bomfa communities, Ghana. Transactions of the Royal Society of Tropical Medicine and Hygiene 2011;105(8):459-65.

\section{Barogui 2016 \{published data only\}}

Barogui YT, Klis SA, Johnson RC, Phillips RO, van der Veer E, van Diemen C, et al. Genetic susceptibility and predictors of paradoxical reactions in Buruli ulcer. PLoS Neglected Tropical Diseases 2016;10(4):e0004594.

\section{Beissner 2015 \{published data only\}}

Beissner M, Arens N, Wiedemann F, Piten E, Kobara B, Bauer M, et al. Treatment outcome of patients with Buruli ulcer disease in Togo. PLoS Neglected Tropical Diseases 2015;9(10):e0004170.

\section{BURULICO Study 2010 \{published data only\}}

Klis S, Stienstra Y, Phillips RO, Abass KM, Tuah W, van der Werf TS. Long term streptomycin toxicity in the treatment of Buruli ulcer: follow-up of participants in the BURULICO drug trial. PLoS Neglected Tropical Diseases 2014;8(3):e2739.

* Nienhuis WA, Stienstra Y, Thompson WA, Awuah PC, Abass KM, Tuah W, et al. Antimicrobial treatment for early, limited Mycobacterium ulcerans infection: a randomized controlled trial. Lancet 2010;375(9715):664-72.

\section{Chauty 2007 \{published data only\}}

Chauty A, Ardant MF, Adeye A, Euverte H, Guédénon A, Johnson C, et al. Promising clinical efficacy of streptomycinrifampin combination for treatment of Buruli ulcer (Mycobacterium ulcerans disease). Antimicrobial Agents and Chemotherapy 2007;51(11):4029-35.

\section{Chauty 2011 \{published data only\}}

Chauty A, Ardant MF, Marsollier L, Pluschke G, Landier J, Adeye A, et al. Oral treatment for Mycobacterium ulcerans infection: results from a pilot study in Benin. Clinical Infectious Diseases 2011;52(1):94-6.

\section{Espey 2002 \{published data only\}}

Espey DK, Djomand G, Diomande I, Dosso M, Saki MZ, Kanga JM, et al. A pilot study of treatment of Buruli ulcer with rifampin and dapsone. International Journal of Infectious Diseases 2002;6(1):60-5

\section{Etuaful 2005 \{published data only\}}

Etuaful S, Carbonnelle B, Grosset I, Lucas S, Horsfield C, Phillips R, et al. Efficacy of combination rifampicin-streptomycin in preventing growth of Mycobacterium ulcerans in early lesions of Buruli ulcer in humans. Antimicrobial Agents and Chemotherapy 2005;49(8):3182-6.

\section{Fehr 1994 \{published data only\}}

Fehr H, Egger M, Senn I. Cotrimoxazol in the treatment of Mycobacterium ulcerans infection (Buruli ulcer) in West Africa. Tropical Doctor 1994;24(2):61-3.

\section{Friedman 2016 \{published data only\}}

Friedman ND, Athan E, Hughes AJ, Khajehnoori M, McDonald A, Callan $\mathrm{P}$, et al. Mycobacterium ulcerans disease: experience with primary oral medical therapy in an Australian cohort. PLoS Neglected Tropical Diseases 2013;7(7):e2315.

* Friedman ND, Athan E, Walton AL, O'Brien DP. Increasing experience with primary oral medical therapy for Mycobacterium ulcerans disease in an Australian cohort. Antimicrobial Agents and Chemotherapy 2016;60(5):2692-5.

Kibadi 2010 \{published data only\}

Kibadi K, Boelaert M, Fraga AG, Kayinua M, Longatto-Filho A, Minuku JB, et al. Response to treatment in a prospective cohort of patients with large ulcerated lesions suspected to be Buruli ulcer (Mycobacterium ulcerans disease). PLoS Neglected Tropical Diseases 2010;4(7):e736.

\section{Lunn 1964 \{published data only\}}

Lunn HF, Rees RJW. Treatment of mycobacterial skin ulcers in Uganda with a Riminophenazine derivative (B.663). Lancet 1964;1(7327):247-9.

\section{O'Brien 2012 \{published data only\}}

O'Brien DP, Hughes AJ, Cheng AC, Henry MJ, Callan P, McDonald A, et al. Outcomes for Mycobacterium ulcerans infection with combined surgery and antibiotic therapy: findings from a south-eastern Australian case series. Medical Journal of Australia 2007;186(2):58-61.

* O'Brien DP, McDonald A, Callan P, Robson M, Friedman ND, Hughes $A$, et al. Successful outcomes with oral fluoroquinolones combined with rifampicin in the treatment of Mycobacterium ulcerans: an observational cohort study. PLoS Neglected Tropical Diseases 2012;6:e1473.

O'Brien 2013b \{published data only\}

O'Brien DP, Robson M, Friedman ND, Walton A, McDonald A, Callan P, et al. Incidence, clinical spectrum, diagnostic features, treatment and predictors of paradoxical reactions during antibiotic treatment of Mycobacterium ulcerans infections. BMC Infectious Diseases 2013;13:416.

\section{Phillips 2014a \{published data only\}}

Phillips RO, Sarfo FS, Abass MK, Abotsi J, Wilson T, Forson M, et al. Clinical and bacteriological efficacy of rifampin-streptomycin combination for two weeks followed by rifampin and clarithromycin for six weeks for treatment of Mycobacterium ulcerans disease. Antimicrobial Agents and Chemotherapy 2014;58(2):1161-6. 
Revill 1973 \{published data only\}

Revill WD, Morrow RH, Pike MC, Ateng J. A controlled trial of the treatment of Mycobacterium ulcerans infection with clofazimine. Lancet 1973;2(7834):873-7.

\section{Sarfo 2010 \{published data only\}}

Sarfo FS, Phillips R, Asiedu K, Ampadu E, Bobi N, Adentwe E, et al. Clinical efficacy of combination of rifampin and streptomycin for treatment of Mycobacterium ulcerans disease. Antimicrobial Agents and Chemotherapy 2010;54(9):3678-85.

\section{References to studies excluded from this review}

\section{Addison 2015 \{published data only\}}

Addison NO, Pfau S, Koka E, Aboagye S, Pluschke G, YeboahManu D, et al. Diagnosis and management of Buruli ulcer patients at a health centre in Ghana. 9th European Congress on Tropical Medicine and International Health; 2015 Sept 6-10; Basel, Switzerland. 2015:244.

\section{Adjei 1998 \{published data only\}}

Adjei O, Evans MR, Asiedu A. Phenytoin in the treatment of Buruli ulcer. Transactions of the Royal Society of Tropical Medicine and Hygiene 1998;92(1):108-9.

\section{Adou 2009 \{published data only\}}

Adou L. Buruli ulcer re-emergent infection. Bacteriologia, Virusologia, Parazitologia, Epidemiologia 2009;54(2):125-33.

\section{Adu 2011 \{published data only\}}

Adu E, Ampadu E, Acheampong D. Surgical management of Buruli ulcer disease: a four-year experience from four endemic districts in Ghana. Ghana Medical Journal 2011;45(1):4-9.

\section{Adu 2015 \{published data only\}}

Adu EJ, Ampadu E. Mycobacterium ulcerans disease in the middle belt of Ghana: an eight-year review from six endemic districts. International Journal of Mycobacteriology 2015;4(2):138-42.

\section{Aguiar 1997 \{published data only\}}

Aguiar J, Stenou C. Buruli ulcers in rural areas of Benin: management of 635 cases. Medicine Tropical (Mars) 1997;57(1):83-90.

\section{Alferink 2013 \{published data only\}}

Alferink M, van der Werf TS, Sopoh GE, Agossadou DC, Barogui YT, Assouto F, et al. Perceptions on the effectiveness of treatment and the timeline of Buruli ulcer influence prehospital delay reported by healthy individuals. PLoS Neglected Tropical Diseases 2013;7(1):e2014.

\section{Alffenaar 2010 \{published data only\}}

Alffenaar JW, Nienhuis WA, de Velde F, Zuur AT, Wessels AM, Almeida $D$, et al. Pharmacokinetics of rifampin and clarithromycin in patients treated for Mycobacterium ulcerans infection. Antimicrobial Agents and Chemotherapy 2010;54(9):3878-83

\section{Anonymous 2010 \{published data only\}}

Anonymous. Buruli ulcer. A disabling infection. Prescrire International 2010;19(110):261-2.

Arens 2015 \{published data only\}

Arens N, Nitschke J, Wiedemann FX, Piten E, Gadah D, Amekuse K, et al. Treatment outcome of patients with Buruli ulcer disease - a clinical follow-up study from Togo. 9th European Congress on Tropical Medicine and International Health (Basel, Switzerland). 2015:244-5.

\section{Azanmasso 2013 \{published data only\}}

Azanmasso H, Addy Lolla B, Diagne NS, Kpadonou GT, Alagnide E, Lmidmani F, et al. Interest of followed children operated for Buruli ulcer in Benin. 28e Congres de Medecine Physique et de Readaptation (Reims, France). 2013:e284-5.

Bamberger 2011 \{published data only\}

Bamberger D, Jantzer N, Leidner K, Arend J, Efferth T. Fighting mycobacterial infections by antibiotics, phytochemicals and vaccines. Microbes and Infection 2011;13(7):613-23.

\section{Barogui 2009 \{published data only\}}

Barogui Y, Johnson RC, van der Werf TS, Sopoh G, Dossou A, Dijkstra PU, et al. Functional limitations after surgical or antibiotic treatment for Buruli ulcer in Benin. American Journal of Tropical Medicine and Hygiene 2009;81(1):82-7.

\section{Barogui 2013 \{published data only\}}

Barogui YT, Klis S, Bankolé HS, Sopoh GE, Mamo S, BabaMoussa L, et al. Towards rational use of antibiotics for suspected secondary infections in Buruli ulcer patients. PLOS Neglected Tropical Diseases 2013;7(1):e2010.

\section{Cornet 1992 \{published data only\}}

Cornet L, Richard-Kadio M, N'Guessan HA, Yapo P, Hossoko H, Dick R, et al. Treatment of Buruli's ulcers by excision-graft. Bulletin de la Societe de Pathologie Exotique 1992;85(5):355-8.

\section{Cowan 2015 \{published data only\}}

Cowan R, Athan E, Friedman ND, Hughes AJ, McDonald A, Callan $\mathrm{P}$, et al. Mycobacterium ulcerans treatment - can antibiotic duration be reduced in selected patients?. PLOS Neglected Tropical Diseases 2015;9(2):e0003503.

Darie 1993 \{published data only\}

Darie H, Le Guyadec T, Touze JE. Epidemiological and clinical aspects of Buruli ulcer in Ivory Coast. 124 recent cases. Bulletin de la Societe de Pathologie Exotique 1993;86(4):272-6.

\section{Debacker 2005 \{published data only\}}

Debacker M, Aguiar J, Steunou C, Zinsou C, Meyers WM, Portaels F. Buruli ulcer recurrence, Benin. Emerging Infectious Diseases 2005;11(4):584-9.

\section{de Bergeyck 1980 \{published data only\}}

de Bergeyck E, Janssens PG, de Muynck A. Radiological abnormalities of the ileum associated with the use of clofazimine (Lamprene; B663) in the treatment of skin ulceration due to Mycobacterium ulcerans. Leprosy Review 1980;51(3):221-8. 
Friedman 2012 \{published data only\}

Friedman ND, McDonald AH, Robson ME, O'Brien DP. Corticosteroid use for paradoxical reactions during antibiotic treatment for Mycobacterium ulcerans. PLoS Neglected Tropical Diseases 2012;6(9):e1767.

\section{Gordon 2010 \{published data only\}}

Gordon CL, Buntine JA, Hayman JA, Lavender CJ, Fyfe JA, Hosking $P$, et al. All-oral antibiotic treatment for Buruli ulcer: a report of four patients. PLoS Neglected Tropical Diseases 2010;4(11):e770.

\section{Guerra 2008 \{published data only\}}

Guerra H, Palomino JC, Falconi E, Bravo F, Donaires N, Van Marck E, et al. Mycobacterium ulcerans disease, Peru. Emerging Infectious Diseases 2008;14(3):373-7.

\section{Josse 1994 \{published data only\}}

Josse R, Guédénon A, Aguiar J, Anagonou S, Zinsou C, Prost C, et al. Buruli's ulcer, a pathology little known in Benin. Apropos of 227 cases. Bulletin de la Societe de Pathologie Exotique 1994;87(3):170-5.

\section{Kanga 2003 \{published data only\}}

Kanga JM, Kacou DE, Sangare A, Dabila Y, Asse NH, Djakeaux S. Recurrence after surgical treatment of Buruli ulcer in Cote d'Ivoire. Bulletin de la Societe de Pathologie Exotique 2003;96(5):406-9.

\section{Kibadi 2007 \{published data only\}}

Kibadi K. Streptomycin injections for the treatment of Mycobacterium ulcerans (Buruli ulcer) in a rural health zone in the Democratic Republic of the Congo. Sante 2007;17(3):173-6.

\section{Klis 2014a \{published data only\}}

Klis SA, Stienstra Y, Phillips RO, Abass KM, Tuah W, Werf TS. Long term streptomycin toxicity in the treatment of Buruli ulcer: follow-up of participants in the BURULICO drug trial. PLOS Neglected Tropical Diseases 2014;8(3):e2739.

\section{Klis 2014b \{published data only\}}

Klis S, Kingma R, Tuah W, Stienstra Y, van der Werf TS. Compliance with antimicrobial therapy for Buruli ulcer. Antimicrobial Agents and Chemotherapy 2014;58(10):6340.

\section{Klis 2014c \{published data only\}}

Klis S, Ranchor A, Phillips RO, Abass KM, Tuah W, Loth S, et al. Good quality of life in former Buruli ulcer patients with small lesions: long-term follow-up of the BURULICO trial. PLOS Neglected Tropical Diseases 2014;8(7):e2964.

\section{Klis 2014d \{published data only\}}

Klis S, van der Werf TS, Phillips RO, Sarfo FS, WansbroughJones M, Stienstra Y. Oral treatment for patients with Buruli ulcer co-infected with HIV: think twice. AIDS 2014;28(5):797-8.

\section{Klis 2016 \{published data only\}}

Klis S, Kingma RA, Tuah W, van der Werf TS, Stienstra Y. Clinical outcomes of Ghanaian Buruli ulcer patients who defaulted from antimicrobial therapy. Tropical Medicine \& International Health 2016;21(9):1191-6.
Kotey 2011 \{published data only\}

Kotey NK, Ampadu X. Antibiotic treatment outcomes of Buruli ulcer in Akwapem South and Suhum-Kraboa-Coaltar districts of Eastern region, Ghana. 7th European Congress on Tropical Medicine and International Health (Barcelona, Spain). 2011:195.

Lunn 1965 \{published data only\}

Lunn HF, Connor DH, Wilks NE, Barnley GR, Kamunvi F, Clancey JK, et al. Buruli (mycobacterial) ulceration in Uganda. (A new focus of Buruli ulcer in Madi District, Uganda): report of a field study. East African Medical Journal 1965;42:275-88.

Marion 2015 \{published data only\}

Marion E, Carolan K, Adeye A, Kempf M, Chauty A, Marsollier L. Buruli ulcer in South Western Nigeria: a retrospective cohort study of patients treated in Benin. PLoS Neglected Tropical Diseases 2015;9(1):e3443.

Milánkovits 2010 \{published data only\}

Milánkovits M. Combined local and vaginal therapy in Buruli ulcer. Orvosi Hetilap 2010;151(35):1434-5.

\section{Mou 2015 \{published data only\}}

Mou F, Um Boock A, Awah PK, Mbah E, Koin J, Nichter M. Developing a Buruli ulcer community of practice in Bankim Cameroon as a model for BU outreach in Africa. 9th European Congress on Tropical Medicine and International Health (Basel, Switzerland). 2015:101.

\section{Nienhuis 2012 \{published data only\}}

Nienhuis WA, Stienstra Y, Abass KM, Tuah W, Thompson WA, Awuah PC, et al. Paradoxical responses after start of antimicrobial treatment in Mycobacterium ulcerans infection. Clinical Infectious Diseases 2012;54(4):519-26.

O'Brien 2014 \{published data only\}

O'Brien DP, Friedman ND, McDonald A, Callan P, Hughes A, Athan E. Clinical features and risk factors of oedematous Mycobacterium ulcerans lesions in an Australian population: beware cellulitis in an endemic area. PLoS Neglected Tropical Diseases 2014;8(1):e2612.

\section{Oluwasanmi 1975 \{published data only\}}

Oluwasanmi JO, Itayemi SO, Alabi GO. Buruli (mycobacterial) ulcers in Caucasians in Nigeria. British Journal of Plastic Surgery 1975;28(2):111-3.

\section{Pfau 2015 \{published data only\}}

Pfau S, Addison NO, Pluschke G, Yeboah-Manu D, Junghanss T. Chronic ulcers in Buruli ulcer patients following specific treatment in a district hospital in Ghana. 9th European Congress on Tropical Medicine and International Health (Basel, Switzerland). 2015:243-4

\section{Phanzu 2006 \{published data only\}}

Phanzu DM, Bafende EA, Dunda BK, Imposo DB, Kibadi AK, Nsiangana SZ, et al. Mycobacterium ulcerans disease (Buruli ulcer) in a rural hospital in Bas-Congo, Democratic Republic of Congo, 2002-2004. American Journal of Tropical Medicine and Hygiene 2006;75(2):311-4

Drugs for treating Buruli ulcer (Mycobacterium ulcerans disease) (Review) 


\section{Phanzu 2011 \{published data only\}}

Phanzu DM, Suykerbuyk P, Imposo DB, Lukanu PN, Minuku JB, Lehman LF, et al. Effect of a control project on clinical profiles and outcomes in Buruli ulcer: a before/after study in Bas-Congo, Democratic Republic of Congo. PLoS Neglected Tropical Diseases 2011;5(12):e1402.

\section{Phillips 2004 \{published data only\}}

Phillips R, Adjei O, Lucas S, Benjamin N, WansbroughJones M. Pilot randomized double-blind trial of treatment of Mycobacterium ulcerans disease (Buruli ulcer) with topical nitrogen oxides. Antimicrobial Agents and Chemotherapy 2004;48(8):2866-70.

\section{Phillips 2014b \{published data only\}}

Phillips RO, Sarfo FS, Abass MK, Frimpong M, Ampadu E, Forson M, et al. Reply to "compliance with antimicrobial therapy for buruli ulcer". Antimicrobial Agents and Chemotherapy 2014;58(10):6341.

\section{Ruf 2011 \{published data only\}}

Ruf MT, Sopoh GE, Brun LV, Dossou AD, Barogui YT, Johnson RC, et al. Histopathological changes and clinical responses of Buruli ulcer plaque lesions during chemotherapy: a role for surgical removal of necrotic tissue?. PLoS Neglected Tropical Diseases 2011;5(9):e1334.

\section{Ruf 2015 \{published data only\}}

Ruf MT, Andreoli A, Sopoh GE, Schmid P, Pluschke G. Immunohistochemical monitoring of wound healing in Buruli ulcer patients treated with RIF/STR. 9th European Congress on Tropical Medicine and International Health (Basel, Switzerland). 2015:241.

\section{Saka 2013 \{published data only\}}

Saka B, Landoh DE, Kobara B, Djadou KE, Yaya I, Yékplé KB, et al. Profile of Buruli ulcer treated at the National Reference Centre of Togo: a study of 119 cases. Bulletin de la Societe de Pathologie Exotique 2013;106(1):32-6.

\section{Schunk 2009 \{published data only\}}

Schunk M, Thompson W, Klutse E, Nitschke J, OpareAsamoah K, Thompson R, et al. Outcome of patients with Buruli ulcer after surgical treatment with or without antimycobacterial treatment in Ghana. American Journal of Tropical Medicine and Hygiene 2009;81(1):75-81.

\section{Schütte 2009 \{published data only\}}

Schütte D, Umboock A, Pluschke G. Phagocytosis of Mycobacterium ulcerans in the course of rifampicin and streptomycin chemotherapy in Buruli ulcer lesions. British Journal of Dermatology 2009;160(2):273-83.

\section{Stienstra 2012 \{published data only\}}

Stienstra Y, Barogui Y, Klis S, Bankole HS, Sopoh G, Mamo S, et al. Towards rational use of antibiotics for suspected secondary infections in Buruli ulcer patients. 61st Annual Meeting of the American Society of Tropical Medicine and Hygiene (Atlanta, GA United States). 2012; Vol. 87 (5 suppl. 1):235.

\section{Teelken 2003 \{published data only\}}

Teelken MA, Stienstra Y, Ellen DE, Quarshie E, Klutse E, van der Graaf WT, et al. Buruli ulcer: differences in treatment outcome between two centres in Ghana. Acta Tropica 2003;88(1):51-6.

\section{van der Werf 1989 \{published data only\}}

van der Werf TS, van der Graaf WT, Groothuis DG, Knell AJ. Mycobacterium ulcerans infection in Ashanti region, Ghana. Transactions of the Royal Society of Tropical Medicine and Hygiene 1989;83(3):410-3.

\section{Vignier 2014 \{published data only\}}

Vignier N, Kempf M, Vignes D, Gousseff M, Alexandre M, Mechai F, et al. Buruli ulcer acquired in Mali: a rare and atypical situation. Travel Medicine and Infectious Disease 2014;12 (6 Pt B):781-2.

\section{Vuagnat 2011 \{published data only\}}

Vuagnat $\mathrm{H}$, Tientcheu G, Comte E. Buruli ulcer treatment in Cameroon, measuring the implementation of a rehabilitation program in a low resource setting. 2011 American Congress of Rehabilitation Medicine, ACRM - American Society of Neurorehabilitation, ASNR Annual Conference (Atlanta, GA United States). 2011:1733-4.

\section{Yeboah-Manu 2013 \{published data only\}}

Yeboah-Manu D, Kpeli GS, Ruf MT, Asan-Ampah K, QueninFosu K, Owusu-Mireku E, et al. Assessment of bacterial burden of Buruli ulcer (BU) lesions: a call for clear guidelines on wound care module for BU case management. 62nd Annual Meeting of the American Society of Tropical Medicine and Hygiene, ASTMH 2012 (Washington, DC United States). 2013; Vol. 89 (5 SUPPL. 1):28-9.

\section{References to ongoing studies}

\section{NCT01432925 \{published and unpublished data\}}

NCT01432925. Timing of surgical intervention in Buruli ulcer patients treated with antibiotics (Burulitime) [Timing of the decision on surgical intervention for Buruli ulcer patients treated with rifampicin/streptomycin]. clinicaltrials.gov/ct2/ show/NCT01432925 (first received 13 September 2011).

NCT01659437 \{published and unpublished data\}

NCT01659437. WHO drug study for Buruli ulcer-comparison of SR8 and CR8 [Randomized controlled trial comparing efficacy of 8 weeks treatment with clarithromycin and rifampicin versus streptomycin and rifampicin for Buruli ulcer (M. ulcerans infection)]. clinicaltrials.gov/ct2/show/NCT01659437 (first received 7 August 2012).

\section{Additional references}

\section{Amofah 1998}

Amofah G, Asamoah S, Afram-Gyening C. Effectiveness of excision of pre-ulcerative Buruli lesions in field situations in a rural district in Ghana. Tropical Doctor 1998;28(2):81-3. 


\section{Asiedu 1998}

Asiedu K, Etuaful S. Socioeconomic implications of Buruli ulcer in Ghana: a three-year review. American Journal of Tropical Medicine and Hygiene 1998;59(6):1015-22.

\section{Boyd 2012}

Boyd SC, Athan E, Friedman ND, Hughes A, Walton A, Callan P, et al. Epidemiology, clinical features and diagnosis of Mycobacterium ulcerans in an Australian population. Medical Journal of Australia 2012;196(5):341-4.

\section{Bradley 1971}

Bradley DJ, for the Uganda Buruli study group. Epidemiology of Mycobacterium ulcerans infection (Buruli ulcer) at Kinyara, Uganda. Transactions of the Royal Society of Tropical Medicine and Hygiene 1971;65(6):763-75.

\section{Bär 1998}

Bär W, Rüsch-Gerdes S, Richter E, Marquéz de Bär G, Dittmer C, Papsdorf $\mathrm{H}$, et al. Mycobacterium ulcerans infection in a child from Angola: diagnosis by direct detection and culture. Tropical Medicine \& International Health 1998;3(3):189-96.

\section{Clancey 1961}

Clancey JK, Dodge OG, Lunn HF, Oduori ML. Mycobacterial skin ulcers in Uganda. Lancet 1961;2(7209):951-4.

\section{Couppié 2015}

Couppié P, Douine M, Gozlan RE, Reynaud Y, Morris A, Sanhueza D, et al. Mycobacterium ulcerans (Buruli ulcer) infection in French Guiana in 2015; epidemiological assessment and status of research. WHO Meeting on Buruli ulcer: Control and Research. Geneva: World Health Organization, 23-25 March 2015:65.

\section{Darie 1994}

Darie H, Djakeaux S, Cautoclaud A. Therapeutic approach in Mycobacterium ulcerans infections [Approche thérapeutique des infections à Mycobacterium ulcerans]. Bulletin de la Société de Pathologie Exotique 1994;87(1):19-21.

\section{Eddyani 2004}

Eddyani M, Ofori-Adjei D, Teugels G, De Weirdt D, Boakye D, Meyers WM, et al. Potential role for fish in transmission of Mycobacterium ulcerans disease (Buruli ulcer): an environmental study. Applied and Environmental Microbiology 2004;70(9):5679-81.

\section{Evans 2003}

Evans MR, Mawdsley J, Bull R, Lockwood DN, Thangaraj H, Shanahan D, et al. Buruli ulcer in a visitor to London. British Journal of Dermatology 2003;149(4):907-9.

\section{Ezzedine 2009}

Ezzedine K, Pistone T, Cottin J, Marsollier L, Guir V, Malvy D. Buruli ulcer in long-term traveller to Senegal. Emerging Infectious Diseases 2009;15(1):118-9.

\section{Faber 2000}

Faber WR, Arias-Bouda LM, Zeegelaar JE, Kolk AH, Fonteyne PA, Toonstra J, et al. First reported case of Mycobacterium ulcerans infection in a patient from China. Transactions of the Royal Society of Tropical Medicine and Hygiene 2000;94(3):277-9.

\section{Farber 1967}

Farber ER, Tsang A. Mycobacterial ("Buruli") ulcer in a Peace Corps worker. Archives of Surgery 1967;95(2):297-300.

\section{Friedman 2013}

Friedman ND, Athan E, Hughes AJ, Khajehnoori M, McDonald A, Callan $P$, et al. Mycobacterium ulcerans disease: experience with primary oral medical therapy in an Australian cohort. PLOS Neglected Tropical Diseases 2013;7(7):e2315.

\section{Gordon 2011}

Gordon CL, Buntine JA, Hayman JA, Lavender CJ, Fyfe JA, Hosking $P$, et al. Spontaneous clearance of Mycobacterium ulcerans in a case of Buruli ulcer. PLoS Neglected Tropical Diseases 2011;5(10):e1290.

\section{GRADEpro GDT 2015 [Computer program]}

McMaster University (developed by Evidence Prime, Inc.). GRADEpro GDT. Version (accessed 6 August 2016). Hamilton (ON): McMaster University (developed by Evidence Prime, Inc.), 2015.

\section{Grietens 2008}

Grietens KP, Um Boock A, Hausmann-Muela S, Toomer E, Ribera JM. "It is me who endures but my family that suffers": social isolation as a consequence of the household cost burden of Buruli ulcer free of charge hospital treatment. PLoS Neglected Tropical Diseases 2008;2:e321.

\section{Higgins 2011}

Higgins JPT, Altman DG, Stern JAC on behalf of the Cochrane Statistical Methods Group and the Cochrane Bias Methods Group. Chapter 8: Assessing risk of bias in included studies. In: Higgins JP, Green S, editor(s). Cochrane Handbook for Systematic Reviews of Interventions Version 5.1.0 (updated March 2011). The Cochrane Collaboration, 2011. Available from handbook.cochrane.org.

\section{Igo 1988}

Igo JD, Murthy DP. Mycobacterium ulcerans infections in Papua New Guinea: correlation of clinical, histological, and microbiologic features. American Journal of Tropical Medicine and Hygiene 1988;38(2):391-2.

\section{Johnson 2005a}

Johnson PD, Stinear T, Small PL, Pluschke G, Merritt RW, Portaels F, et al. Buruli ulcer (M. ulcerans infection): new insights, new hope for disease control. PLoS Medicine 2005;2(4):e108.

\section{Johnson 2005b}

Johnson RC, Sopoh GE, Boko M, Zinsou C, Gbovi J, Makoutode $\mathrm{M}$, et al. Distribution of Mycobacterium ulcerans (Buruli ulcer) in the district of Lalo in Benin [Distribution de l'infection à Mycobacterium ulcerans (Ulcère de Buruli) dans la commune de Lalo au Bénin]. Tropical Medicine \& International Health 2005;10(9):863-71.

Drugs for treating Buruli ulcer (Mycobacterium ulcerans disease) (Review)

Copyright $\odot 2018$ The Authors. Cochrane Database of Systematic Reviews published by John Wiley \& Sons, Ltd. on behalf of The Cochrane Collaboration. 


\section{Joseph 2003}

Sister Joseph. Mycobacterium ulcerans in Papua New Guinea, 2002. In: Report of the 6th WHO Advisory Group Meeting on Buruli Ulcer, 10-13 March 2003, WHO headquarters, Geneva, Switzerland; p44-7. apps.who.int/iris/bitstream/10665/68508/1/ WHO_CDS_CPE_GBUI_2003.8.pdf (accessed prior to 5 February 2016). [WHO/CDS/CPE/GBUI/2003.8]

\section{Junghanss 2009}

Junghanss T, Um Boock A, Vogel M, Schuette D, Weinlaeder H, Pluschke $G$. Phase change material for thermotherapy of Buruli ulcer: a prospective observational single centre proof-ofprinciple trial. PLoS Neglected Tropical Diseases 2009;3(2):e380.

\section{Juni 2001}

Juni P, Altman DG, Egger M. Systematic reviews in health care: assessing the quality of controlled clinical trials. $B M J$ 2001;323(7303):42-6.

\section{Kibadi 2006}

Kibadi AK. Relapses after surgical treatment of Buruli ulcer in Africa [Les rechutes après traitement de l'ulcère de Buruli par la chirurgie en Afrique]. Bulletin de la Société de Pathologie Exotique 2006;99(4):230-5.

\section{Klis 2014}

Klis S, Stienstra Y, Thompson WA, van der Werf TS. Long term streptomycin toxicity in the treatment of Buruli ulcer: followup of participants in the BURULICO drug trial. PLoS Neglected Tropical Diseases 2014;8(3):e2739.

\section{Klutse 2003}

Klutse EY, Adjei I, Ampadu E, Arthur L. Management of Buruli ulcer cases with topical application of phenytoin powder. In: Report of the 6th WHO Advisory Group Meeting on Buruli ulcer. 10-13 March 2003, WHO headquarters, Geneva, Switzerland; p.103-12. apps.who.int/iris/bitstream/10665/68508/1/WHO_ CDS_CPE_GBUI_2003.8.pdf (accessed prior to 5 February 2016). [WHO/CDS/CPE/GBUI/2003.8]

\section{Krieg 1975}

Krieg RE, Wolcott JH, Confer A. Treatment of Mycobacterium ulcerans infection by hyperbaric oxygenation. Aviation, Space, and Environmental Medicine 1975;46(10):1241-5.

\section{Krieg 1979}

Krieg RE, Wolcott JH, Meyers WM. Mycobacterium ulcerans infection: treatment with rifampin, hyperbaric oxygenation, and heat. Aviation, Space, and Environmental Medicine 1979;50(9):888-92.

\section{MacCallum 1948}

MacCallum P, Tolhurst JC, Buckle G, Sissons HA. A new mycobacterial infection in man. Journal of Pathology and Bacteriology 1948;60(1):93-122.

\section{Marsollier 2002}

Marsollier L, Robert R, Aubry J, Saint André JP, Kouakou H, Legras $P$, et al. Aquatic insects as a vector for Mycobacterium ulcerans. Applied and Environmental Microbiology 2002;68(9):4623-8.

\section{Marsollier 2003}

Marsollier L, Honoré N, Legras P, Manceau AL, Kouakou H, Carbonnelle $\mathrm{B}$, et al. Isolation of three Mycobacterium ulcerans strains resistant to rifampin after experimental chemotherapy of mice. Antimicrobial Agents and Chemotherapy 2003;47(4):1228-32.

\section{Marston 1995}

Marston BJ, Diallo MO, Horsburgh CR Jr, Diomande I, Saki MZ, Kanga JM, et al. Emergence of Buruli ulcer disease in the Daloa region of Cote d'Ivoire. American Journal of Tropical Medicine and Hygiene 1995;52(3):219-24.

\section{Merritt 2010}

Merritt RW, Walker ED, Small PL, Wallace JR, Johnson PD, Benbow ME, et al. Ecology and transmission of Buruli ulcer disease: a systematic review. PLoS Neglected Tropical Diseases 2010;4(12):e911.

\section{Meyers 1974}

Meyers WM, Shelly WM, Connor DH. Heat treatment of Mycobacterium ulcerans infections without surgical excision. American Journal of Tropical Medicine and Hygiene 1974;23(5):924-9.

\section{Nienhuis 2010}

Nienhuis WA, Stienstra Y, Thompson WA, Awuah PC, Abass KM, Tuah W, et al. Antimicrobial treatment for early, limited Mycobacterium ulcerans infection: a randomized controlled trial. Lancet 2010;375(9715):664-72.

\section{O'Brien 2007}

O'Brien DP, Hughes AJ, Cheng AC, Henry MJ, Callan P, McDonald A, et al. Outcomes for Mycobacterium ulcerans infection with combined surgery and antibiotic therapy: findings from a south-eastern Australian case series. Medical Journal of Australia 2007;186(2):58-61.

\section{O'Brien 2009}

O'Brien DP, Robson ME, Callan PP, McDonald AH. 'Paradoxical' immune-mediated reactions to Mycobacterium ulcerans during antibiotic treatment: a result of treatment success, not failure. Medical Journal of Australia 2009;191(10):564-6.

\section{O'Brien 2013a}

O'Brien DP, Walton A, Hughes AJ, Friedman ND, McDonald A, Callan P, et al. Risk factors for recurrent Mycobacterium ulcerans disease after exclusive surgical treatment in an Australian cohort. Medical Journal of Australia 2013;198(8):436-9.

\section{Phillips 2004a}

Phillips R, Adjei O, Lucas S, Benjamin N, WansbroughJones M. Pilot randomized double-blind trial of treatment of Mycobacterium ulcerans disease (Buruli ulcer) with topical nitrogen oxides. Antimicrobial Agents and Chemotherapy 2004;48(8):2866-70.

\section{Phillips 2004b}

Phillips R, Kuijper S, Benjamin N, Wansbrough-Jones M, Wilks M, Kolk AH. In vitro killing of Mycobacterium ulcerans 
by acidified nitrite. Antimicrobial Agents and Chemotherapy 2004;48(8):3130-2.

\section{RevMan 2014 [Computer program]}

Nordic Cochrane Centre, The Cochrane Collaboration. Review Manager 5 (RevMan 5). Version 5.3. Copenhagen: Nordic Cochrane Centre, The Cochrane Collaboration, 2014.

\section{Semret 1999}

Semret M, Koromihis G, MacLean JD, Libman M, Ward BJ. Mycobacterium ulcerans infection (Buruli ulcer): first reported case in a traveler. American Journal of Tropical Medicine and Hygiene 1999;61(5):689-93.

\section{Sizaire 2006}

Sizaire V, Nackers F, Comte E, Portaels F. Mycobacterium ulcerans infection: control, diagnosis, and treatment. Lancet Infectious Diseases 2006;6(5):288-96.

\section{Sterne 2014}

Sterne JAC, Higgins JPT, Reeves BC on behalf of the development group for ACROBAT-NRSI. A Cochrane Risk of Bias Assessment Tool for Non-Randomized Studies of Interventions (ACROBAT-NRSI), Version 1.0.0. Available from: www.riskofbias.info (accessed prior to 8 August 2017).

\section{Sugawara 2015}

Sugawara M, Ishii N, Nakanaga K, Suzuki K, Umebayashi Y, Makigami K, et al. Exploration of a standard treatment for Buruli ulcer through a comprehensive analysis of all Japanese cases. Journal of Dermatology 2015;42:588-95.

\section{Tai 2018}

Tai AYC, Athan E, Friedman D, Hughes A, Walton A, O'Brien DP. Increased severity and spread of Mycobacterium ulcerans, Southeastern Australia. Emerging Infectious Diseases 2018;24(1):58-64.

\section{Tuffour 2015}

Tuffour J, Owusu-Mireku E, Ruf M, Aboagye S, Kpeli G, Akuoku V, et al. Challenges associated with management of Buruli ulcer/ human immunodeficiency virus coinfection in a treatment center in Ghana: a case series study. American Journal of Tropical Medicine and Hygiene 2015;93(2):216-23.

\section{Uganda Buruli Group 1970}

Uganda Buruli Group. Clinical features and treatment of preulcerative Buruli lesions (Mycobacterium ulcerans infection). Report II of the Uganda Buruli Group. British Medical Journal 1970;2(5706):390-3.

\section{van der Werf 1999}

van der Werf TS, Van der Graaf WT, Tappero JW, Asiedu K. Mycobacterium ulcerans infection. Lancet 1999;354(9183):1013-8.

\section{van der Werf 2003}

van der Werf TS, Stinear T, Stienstra Y, van der Graaf WT, Small PL. Mycolactones and Mycobacterium ulcerans disease. Lancet 2003;362(9389):1062-4.

\section{van Oye 1950}

van Oye $\mathrm{E}$, Ballion $\mathrm{M}$. Is it necessary to take into account a new infection from acid-resistant bacilli in Africa? Preliminary note [Faudra-t-il tenir compte d'une nouvelle affection à bacilles acido-résistants en Afrique? Note préliminaire]. Annales de la Société Belge de Médecine Tropicale 1950;30(3):619-27.

\section{Velding 2014}

Velding K, Klis S, Abass KM, Tuah W, Stienstra Y, van der Werf T. Wound care in Buruli ulcer disease in Ghana and Benin. American Journal of Tropical Medicine and Hygiene 2014;91(2):313-8.

\section{Vincent 2014a}

Vincent QB, Ardant MF, Adeye A, Goundote A, Saint-André JP, Cottin J, et al. Clinical epidemiology of laboratory-confirmed Buruli ulcer in Benin: a cohort study. Lancet Global Health 2014;2(7):e422-30.

\section{Vincent 2014b}

Vincent QB, Ardant M, Marsollier L, Chauty A, Alcais A, FrancoBeninese Buruli Research Group. HIV infection and Buruli ulcer in Africa. Lancet Infectious Diseases 2014;14(9):796-7.

\section{Vogel 2016}

Vogel M, Bayi PF, Ruf MT, Bratschi MW, Boiz M, Um Boock A, et al. Local heat application for the treatment of Buruli ulcer: results of a Phase II open label single center non comparative clinical trial. Clinical Infectious Diseases 2016;62(3):342-50.

\section{Vouking 2013}

Vouking MZ, Tamo VC, Tadenfok CN. Clinical efficacy of rifampicin and streptomycin in combination against Mycobacterium ulcerans infection: a systematic review. Pan African Medical Journal 2013;15:155.

\section{Wansbrough-Jones 2006}

Wansbrough-Jones M, Phillips R. Buruli ulcer: emerging from obscurity. Lancet 2006;367(9525):1849-58.

\section{WHO 2004}

Global Buruli Ulcer Initiative, World Health Organization. Provisional Guidance on the Role of Specific Antibiotics in the Management of Mycobacterium ulcerans Disease (Buruli Ulcer). Geneva: World Health Organization, 2004.

\section{WHO 2012}

Global Buruli Ulcer Inititative, World Health Organization. Treatment of Mycobacterium Ulcerans Disease (Buruli Ulcer): Guidance for Health Workers. Geneva: World Health Organization, 2012.

\section{WHO 2013}

World Health Organization's Strategic and Technical Advisory Group for Neglected Tropical Diseases. Sustaining the Drive to Overcome the Global Impact of Neglected Tropical Diseases. Second WHO Report on Neglected Tropical Diseases. Geneva: World Health Organization, 2013. 


\section{WHO 2014}

Global Buruli Ulcer Initiative, World Health Organization. Laboratory Diagnosis of Buruli Ulcer. A Manual for Health Care Providers. Geneva: World Health Organization, 2014.

\section{WHO 2017}

Global Buruli Ulcer Initiative, World Health Organization. Buruli ulcer (Mycobacterium ulcerans infection): fact sheet. www.who.int/mediacentre/factsheets/fs199/en/ (accessed prior to 28 February 2017).

\section{Yotsu 2012}

Yotsu RR, Nakanaga K, Hoshino Y, Suzuki K, Ishii N. Buruli ulcer and current situation in Japan: a new emerging cutaneous Mycobacterium infection. Journal of Dermatology 2012;39(7):587-93.

\section{Yotsu 2015}

Yotsu RR, Murase C, Sugawara M, Suzuki K, Nakanaga K, Ishii N, et al. Revisiting Buruli ulcer. Journal of Dermatology 2015;42(11):1033-41.

* Indicates the major publication for the study

\section{CHARACTERISTICS OF STUDIES}

Characteristics of included studies [ordered by study ID]

Adu 2013

\begin{tabular}{ll}
\hline Methods & Prospective observational study \\
\hline Participants & Inclusion criteria: clinically + laboratory-confirmed BU (exclusion: none stated) \\
& Laboratory confirmation: either by ZN test for acid-fast bacilli (AFB), PCR, or histopathology \\
& Enrolled: 126 participants \\
& Participant characteristics: 64 males, $50.8 \%$; mean age 29.8 (range, 1 year 3 months to 98 years) \\
& Lesion types: ulcer $116(92 \%)$, papule $1(0.5 \%)$, nodule 2 (1.5\%), oedema 4 (3\%), chronic osteomyelitis 2 \\
& $(1.5 \%)$, contractures 2 (1.5\%) (1 participant with both ulcer and contracture) \\
& WHO category I: 12 (10\%), category II: 43 (34\%), category III: 71 (56\%) \\
\hline
\end{tabular}

Interventions

Rifampicin (10 mg/kg/day) + streptomycin (15 mg/kg/day), 8 weeks, with surgery

Surgery: when indicated after antibiotic treatment

Follow-up: N/A

\begin{tabular}{ll}
\hline Outcomes & "Healed without surgery", assessed at 8 weeks \\
& Standardized outcome: possible cure \\
\hline Notes & Trial location: Ghana \\
& Enrolment dates: January 2010 to December 2012 \\
& The primary objective of the study was to document the complications of BU and the reconstructive \\
& surgery performed in patients whose lesions were not completely healed after 8 weeks of antibiotic \\
treatment.
\end{tabular}

\section{Risk of bias}

\begin{tabular}{lll}
\hline Bias & Authors' judgement & Support for judgement \\
\hline $\begin{array}{l}\text { Random sequence genera- } \\
\text { tion (Trials) }\end{array}$ & High risk & - \\
\hline
\end{tabular}

$\begin{aligned} & \text { Allocation concealment } \\ & \text { (Trials) }\end{aligned}$


Adu 2013 (Continued)

\begin{tabular}{lll}
$\begin{array}{l}\text { Blinding of participants } \\
\text { and personnel (Trials) }\end{array}$ & High risk & - \\
\hline $\begin{array}{l}\text { Blinding of outcome as- } \\
\text { sessment (Trials) }\end{array}$ & High risk & -
\end{tabular}

\begin{tabular}{ll}
\hline Selection of participants & Low risk Selection not related to intervention or outcome. \\
into the study (Prospective &
\end{tabular}

observational studies)

Measurement of outcomes Low risk Objective outcome measure (healing)
(Prospective observational
studies)

studies)

\begin{tabular}{lll}
\hline $\begin{array}{l}\text { Incomplete outcome da- } \\
\text { ta / missing data (All stud- } \\
\text { ies) }\end{array}$ & Low risk & No missing data \\
\hline $\begin{array}{l}\text { Selective reporting (All } \\
\text { studies) }\end{array}$ & Low risk & Reported all expected outcomes \\
\hline Other bias & Low risk & No other bias identified. \\
\hline
\end{tabular}

Agbenorku 2011

\begin{tabular}{ll}
\hline Methods & Prospective observational study \\
\hline Participants & Inclusion criteria: clinically + laboratory-confirmed BU (exclusion: none stated) \\
& Laboratory confirmation: any 2 positives of ZN test for AFB, PCR, and histopathology \\
& Enrolled: 189 participants \\
& Participant characteristics: 113 males, $60 \%$; age N/A \\
& Lesion types: ulcer $145(76.7 \%)$, nodule $38(20.1 \%)$, plaque $6(3.2 \%)$ \\
& WHO category I: 44 (22.3\%), categories II + III: $145(76.7 \%)$ \\
\hline
\end{tabular}

Interventions Rifampicin $(10 \mathrm{mg} / \mathrm{kg} / \mathrm{d})+$ streptomycin $(15 \mathrm{mg} / \mathrm{kg} / \mathrm{d}), 8$ weeks, with surgery

Surgery: all cases

Follow-up: 2 years after discharge from hospital

Outcomes $\begin{aligned} & \text { 1. Healing rate } \\ & \text { 2. Recurrence } \\ & \text { 3. Adverse effects } \\ & \text { 4. Mean hospital stay days } \\ & \text { 5. Number of new BU cases and their disease stage at the study site after counselling and health educa- } \\ & \text { tion activities }\end{aligned}$

\section{Standardized outcome: cure}

\begin{tabular}{ll}
\hline Notes & Trial location: Ghana \\
& Enrolment dates: January 2005 to December 2005 \\
\hline
\end{tabular}

Drugs for treating Buruli ulcer (Mycobacterium ulcerans disease) (Review) 
Agbenorku 2011 (Continued)

\section{Risk of bias}

\begin{tabular}{|c|c|c|}
\hline Bias & Authors' judgement & Support for judgement \\
\hline $\begin{array}{l}\text { Random sequence genera- } \\
\text { tion (Trials) }\end{array}$ & High risk & - \\
\hline $\begin{array}{l}\text { Allocation concealment } \\
\text { (Trials) }\end{array}$ & High risk & - \\
\hline $\begin{array}{l}\text { Blinding of participants } \\
\text { and personnel (Trials) }\end{array}$ & High risk & - \\
\hline $\begin{array}{l}\text { Blinding of outcome as- } \\
\text { sessment (Trials) }\end{array}$ & High risk & - \\
\hline $\begin{array}{l}\text { Selection of participants } \\
\text { into the study (Prospective } \\
\text { observational studies) }\end{array}$ & Low risk & Selection not related to intervention or outcome. \\
\hline $\begin{array}{l}\text { Measurement of outcomes } \\
\text { (Prospective observational } \\
\text { studies) }\end{array}$ & Low risk & Objective outcome measure (healing) \\
\hline $\begin{array}{l}\text { Incomplete outcome da- } \\
\text { ta / missing data (All stud- } \\
\text { ies) }\end{array}$ & Low risk & 3 participants (3.2\%) were lost to follow-up but for different outcomes. \\
\hline $\begin{array}{l}\text { Selective reporting (All } \\
\text { studies) }\end{array}$ & Low risk & Reported all expected outcomes \\
\hline Other bias & Low risk & No other bias identified. \\
\hline
\end{tabular}

Barogui 2016

\begin{tabular}{ll}
\hline Methods & Prospective observational study \\
\hline Participants & Inclusion and exclusion criteria: refer to BURULICO Study 2010 and NCT01432925 \\
& Enrolled: 241 participants; 150 from BURULICO Study 2010 and 91 from NCT01432925 \\
& Participant characteristics: 88 (37\%) males, mean (SD) 16.2 (13.2) years \\
& Lesion types: ulcer 108 (45\%), nodule 32 (13\%), plaque 56 (23\%), oedema 11 (5\%), mixed 34 (14\%) \\
& WHO category I: 69 (29\%), category II: 133 (55\%), category III: 39 (16\%) \\
\hline Interventions & Refer to BURULICO Study 2010 and NCT01432925 \\
\hline Outcomes & Paradoxical reaction defined by an initial decrease of the lesion size followed by 2 consecutive increas- \\
\hline es & Trial location: Ghana and Benin \\
\hline Enrolment dates: BURULICO Study 2010, 2006 to 2008; NCT01432925, 2011 to 2015
\end{tabular}


Barogui 2016 (Continued)

Risk of bias

\begin{tabular}{|c|c|c|}
\hline Bias & Authors' judgement & Support for judgement \\
\hline $\begin{array}{l}\text { Random sequence genera- } \\
\text { tion (Trials) }\end{array}$ & High risk & - \\
\hline $\begin{array}{l}\text { Allocation concealment } \\
\text { (Trials) }\end{array}$ & High risk & - \\
\hline $\begin{array}{l}\text { Blinding of participants } \\
\text { and personnel (Trials) }\end{array}$ & High risk & - \\
\hline $\begin{array}{l}\text { Blinding of outcome as- } \\
\text { sessment (Trials) }\end{array}$ & High risk & - \\
\hline $\begin{array}{l}\text { Selection of participants } \\
\text { into the study (Prospective } \\
\text { observational studies) }\end{array}$ & Low risk & Selection not related to intervention or outcome. \\
\hline $\begin{array}{l}\text { Measurement of outcomes } \\
\text { (Prospective observational } \\
\text { studies) }\end{array}$ & Low risk & Objective outcomes clearly defined. \\
\hline $\begin{array}{l}\text { Incomplete outcome da- } \\
\text { ta / missing data (All stud- } \\
\text { ies) }\end{array}$ & Low risk & No loss to follow-up \\
\hline $\begin{array}{l}\text { Selective reporting (All } \\
\text { studies) }\end{array}$ & Low risk & Reported all expected outcomes \\
\hline Other bias & High risk & $\begin{array}{l}\text { Paradoxical reaction was only defined clinically by lesion size; no exams to } \\
\text { support diagnosis. }\end{array}$ \\
\hline
\end{tabular}

Beissner 2015

\begin{tabular}{|c|c|}
\hline Methods & Prospective observational study \\
\hline \multirow[t]{6}{*}{ Participants } & $\begin{array}{l}\text { Inclusion criteria: clinically + laboratory-confirmed BU; any age (exclusion: laboratory-unconfirmed } \\
\text { cases) }\end{array}$ \\
\hline & Laboratory confirmation: IS2404 dry-reagent-based PCR \\
\hline & Enrolled: 199 eligible participants; 70 dropouts (35.2\%); 129 participants analysed \\
\hline & Participant characteristics: 60 males, $46.5 \%$; median 10 years, range 2 to 68 years \\
\hline & Lesion types: ulcer 73 (76.7\%), nodule 19 (14.7\%), plaque $26(20.2 \%)$, oedema $11(8.5 \%)$ \\
\hline & WHO category I: 59 (45.7\%), category II: 44 (34.1\%), category III: 26 (20.2\%) \\
\hline \multirow[t]{3}{*}{ Interventions } & Rifampicin $(10 \mathrm{mg} / \mathrm{kg} / \mathrm{d})+$ streptomycin $(15 \mathrm{mg} / \mathrm{kg} / \mathrm{d}), 8$ weeks \\
\hline & Surgery: when indicated \\
\hline & $\begin{array}{l}\text { Follow-up: follow-up visits were conducted January to April } 2013 \text { (110 participants) and May to June } \\
2014 \text { (19 participants) (> } 6 \text { months elapsed since the end of antimicrobial treatment). }\end{array}$ \\
\hline
\end{tabular}

Drugs for treating Buruli ulcer (Mycobacterium ulcerans disease) (Review) 
Beissner 2015 (Continued)
Outcomes
1. Healed with or without surgery
2. Healing time
3. Secondary lesions
4. Functional limitations
5. Recurrence until the follow-up visit

Standardized outcome: possible cure

\begin{tabular}{ll}
\hline Notes & Trial location: Togo \\
& Enrolment dates: September 2007 to November 2013
\end{tabular}

\section{Risk of bias}

\begin{tabular}{lll}
\hline Bias & Authors' judgement & Support for judgement \\
\hline $\begin{array}{l}\text { Random sequence genera- } \\
\text { tion (Trials) }\end{array}$ & High risk & - \\
\hline
\end{tabular}

\begin{tabular}{lll}
\hline $\begin{array}{l}\text { Allocation concealment } \\
\text { (Trials) }\end{array}$ & High risk & - \\
\hline $\begin{array}{l}\text { Blinding of participants } \\
\text { and personnel (Trials) }\end{array}$ & High risk & - \\
\hline $\begin{array}{l}\text { Blinding of outcome as- } \\
\text { sessment (Trials) }\end{array}$ & High risk & - \\
\hline
\end{tabular}

Selection of participants High risk
into the study (Prospective

Only 129 out of 199 eligible patients could be retrieved and enrolled.

observational studies)

Measurement of outcomes Low risk Objective outcome measure (healing)
(Prospective observational
studies)

\begin{tabular}{lll}
\hline $\begin{array}{l}\text { Incomplete outcome da- } \\
\text { ta / missing data (All stud- } \\
\text { ies) }\end{array}$ & Low risk & No missing data \\
\hline $\begin{array}{l}\text { Selective reporting (All } \\
\text { studies) }\end{array}$ & Low risk & Reported all expected outcomes \\
\hline Other bias & Low risk & No other bias identified. \\
\hline
\end{tabular}

BURULICO Study 2010

\begin{tabular}{ll}
\hline Methods & Randomized controlled trial \\
\hline Participants & $\begin{array}{l}\text { Inclusion criteria: clinically + laboratory-confirmed BU; aged } 5 \text { years or older, had a reported disease } \\
\text { duration of less than } 6 \text { months, and had lesions with a cross-sectional diameter (indurated area) of } 10 \\
\text { cm or less (exclusions: pregnancy, drug intolerance, and renal, hepatic, and acoustic impairment) } \\
\text { Laboratory confirmation: IS2404 dry-reagent-based PCR }\end{array}$
\end{tabular}


BURULICO Study 2010 (Continued)

Enrolled: 151 participants; 143 with infection confirmed by PCR, 5 with infection confirmed by other methods, 3 cases were clinical diagnosis

Participant characteristics: intervention group 19 (25\%) males, median 12 years (IQR 9 to 22); control group 27 (36\%) males, median 12 years (IQR 8 to 18 )

Lesion types: ulcer 59 (39.1\%), non-ulcer 92 (60.9\%)

WHO category I: 58 (38.4\%), category II + III: 93 (61.16\%)

Interventions Rifampicin (10 mg/kg/day) + streptomycin (15 mg/kg/day), 4 weeks followed by rifampicin (10 mg/
$\mathrm{kg} /$ day) + clarithromycin $(7.5 \mathrm{mg} / \mathrm{kg} / \mathrm{day}), 4$ weeks
2. Rifampicin $(10 \mathrm{mg} / \mathrm{kg} / \mathrm{day})+$ streptomycin ( $15 \mathrm{mg} / \mathrm{kg} /$ day), 8 weeks
Surgery: when indicated
Follow-up: once a week participants were given study drugs to take to the nearest health facility to re-
ceive directly observed treatment for the subsequent days, with daily wound care. Participants with
complicated lesions were hospitalized.
Participants were followed up at weekly intervals during the first 8 weeks; at week 10 , week 12 , and
then monthly to week 36 , and bimonthly to week 52 . Study visits included clinical assessment with re-
porting of adverse effects, measurement of lesion size (if not healed) by tracing onto an acetate sheet,
and photography of the lesion.

1. Healed without surgery or recurrence (cure)
2. Cumulative proportion of healing
3. Difference in healing time between the 2 groups
4. Skin grafts
5. Recurrence
6. Functional impairment
7. Adverse effects (ototoxicity, nephrotoxicity, abdominal discomfort) during treatment
8. Long-term adverse effects (ototoxicity, nephrotoxicity) (Klis 2014)

Notes Trial location: Ghana

Enrolment dates: April 2006 to January 2008

HIV antibody testing was done with cold-stored sera after completion of the study, in which $3(2 \%)$ participants were found positive.

\section{Risk of bias}

\begin{tabular}{lll}
\hline Bias & Authors' judgement & Support for judgement \\
\hline $\begin{array}{l}\text { Random sequence genera- } \\
\text { tion (Trials) }\end{array}$ & Low risk & Computer-generated minimization \\
\hline $\begin{array}{l}\text { Allocation concealment } \\
\text { (Trials) }\end{array}$ & Low risk & $\begin{array}{l}\text { Assigned allocation was sent from a central site by text message to study co- } \\
\text { ordinator. }\end{array}$ \\
\hline $\begin{array}{l}\text { Blinding of participants } \\
\text { and personnel (Trials) }\end{array}$ & Low risk & $\begin{array}{l}\text { Open-label, but outcome unlikely to be affected by participant knowledge of } \\
\text { treatment group. }\end{array}$ \\
\hline $\begin{array}{l}\text { Blinding of outcome as- } \\
\text { sessment (Trials) }\end{array}$ & Low risk & $\begin{array}{l}\text { Open-label, but primary endpoint also assessed by blinded wound experts, } \\
\text { and the results concurred with those from the primary analysis. }\end{array}$ \\
\hline
\end{tabular}


BURULICO Study 2010 (Continued) into the study (Prospective observational studies)

Measurement of outcomes Unclear risk
(Prospective observational
studies)

\begin{tabular}{lll}
\hline $\begin{array}{l}\text { Incomplete outcome da- } \\
\text { ta / missing data (All stud- } \\
\text { ies) }\end{array}$ & Low risk & $\begin{array}{l}\text { 4 participants withdrew/died/were lost to follow-up but were still included in } \\
\text { analysis for primary endpoint as the lesion had healed at the last assessment. }\end{array}$ \\
\hline $\begin{array}{l}\text { Selective reporting (All } \\
\text { studies) }\end{array}$ & Low risk & Reported all expected outcomes \\
\hline Other bias & Low risk & 3 cases not laboratory-confirmed, but only a small number. \\
\hline
\end{tabular}

\section{Chauty 2007}

\begin{tabular}{|c|c|}
\hline Methods & Prospective observational study \\
\hline \multirow[t]{6}{*}{ Participants } & Inclusion criteria: clinical diagnosis of BU; residing in an endemic area \\
\hline & $\begin{array}{l}\text { (exclusion criteria: pregnancy; receiving traditional treatment at the time of diagnosis; history of lep- } \\
\text { rosy, TB; liver, kidney, or hearing problems) }\end{array}$ \\
\hline & $\begin{array}{l}\text { Enrolled: } 310 \text { participants; } 36 \text { immediate surgical excision at another centre, } 3 \text { pregnancy, } 47 \text { refusals; } \\
224 \text { analysed }\end{array}$ \\
\hline & $\begin{array}{l}\text { Participant characteristics: among the } 310 \text { eligible participants, } 145 \text { males, } 47 \% ;<15 \text { years, } 179 \text { partici- } \\
\text { pants }(58 \%), 15 \text { to } 49 \text { years, } 90 \text { participants }(29 \%), \geq 50 \text { years, } 41 \text { participants }(13 \%)\end{array}$ \\
\hline & $\begin{array}{l}\text { Lesion types: ulcer } 168(73.8 \%) \text {, of which } 29(18.4 \%) \text { were }<5 \mathrm{~cm}, 76(48.1 \%) \text { were } 4 \text { to } 14 \mathrm{~cm} \text {, and } 63 \\
(39.9 \%) \text { were } \geq 10 \mathrm{~cm} \text {; non-ulcer } 56(26.2 \%)\end{array}$ \\
\hline & WHO category: N/A \\
\hline \multirow[t]{4}{*}{ Interventions } & $\begin{array}{l}8 \text { weeks of rifampicin }(10 \mathrm{mg} / \mathrm{kg} / \text { day })+\text { streptomycin }(15 \mathrm{mg} / \mathrm{kg} / \text { day) was administered to all partici- } \\
\text { pants. During the } 4 \text {-week assessment, participants who were considered unlikely to be cured by antibi- } \\
\text { otics alone (opinion of the treating physician) underwent surgery. }\end{array}$ \\
\hline & $\begin{array}{l}\text { Local dressings were provided for participants with ulcerative lesions. Participants were treated dai- } \\
\text { ly under the direct observation of the clinic nurse either as an outpatient or inpatient. The study physi- } \\
\text { cian evaluated participants every } 2 \text { weeks during treatment. }\end{array}$ \\
\hline & Surgery: when indicated \\
\hline & Follow-up period: 1 year after treatment completion \\
\hline
\end{tabular}

\begin{tabular}{ll}
\hline Outcomes & Successful treatment: completely healed \\
2. Recurrence: reactivation of the disease within 1 year after apparent success upon treatment comple- \\
tion
\end{tabular}

\section{Standardized outcome: probable cure}

\begin{tabular}{ll}
\hline Notes & Trial location: Benin \\
& Enrolment dates: January 2003 to December 2004
\end{tabular}

Drugs for treating Buruli ulcer (Mycobacterium ulcerans disease) (Review) 
Chauty 2007 (Continued)

Risk of bias

\begin{tabular}{|c|c|c|}
\hline Bias & Authors' judgement & Support for judgement \\
\hline $\begin{array}{l}\text { Random sequence genera- } \\
\text { tion (Trials) }\end{array}$ & High risk & - \\
\hline $\begin{array}{l}\text { Allocation concealment } \\
\text { (Trials) }\end{array}$ & High risk & - \\
\hline $\begin{array}{l}\text { Blinding of participants } \\
\text { and personnel (Trials) }\end{array}$ & High risk & - \\
\hline $\begin{array}{l}\text { Blinding of outcome as- } \\
\text { sessment (Trials) }\end{array}$ & High risk & - \\
\hline $\begin{array}{l}\text { Selection of participants } \\
\text { into the study (Prospective } \\
\text { observational studies) }\end{array}$ & High risk & $\begin{array}{l}86 / 310 \text { patients ( } 28 \%) \text { who were eligible for the study were not included; } 3 \\
\text { pregnancies, } 36 \text { immediate surgical excisions at another centre, } 6 \text { participants' } \\
\text { decision to receive traditional treatment, } 41 \text { refusals of antibiotic and/or surgi- } \\
\text { cal treatment. }\end{array}$ \\
\hline
\end{tabular}

Measurement of outcomes Low risk Objective outcome measure (healing)
(Prospective observational

studies)

\begin{tabular}{lll}
$\begin{array}{l}\text { Incomplete outcome da- } \\
\text { ta / missing data (All stud- } \\
\text { ies) }\end{array}$ & High risk & We do not have data for 17 participants who were lost to follow-up at week 8. \\
\hline $\begin{array}{l}\text { Selective reporting (All } \\
\text { studies) }\end{array}$ & Low risk & Reported all expected outcomes \\
\hline Other bias & High risk & $\begin{array}{l}\text { Laboratory exam was attempted in } 145 \text { of the } 168 \text { participants. } 40 / 145(28 \%) \\
\text { were negative for both PCR and smear, indicating that some cases may not } \\
\text { have been BU. }\end{array}$ \\
\hline
\end{tabular}

Chauty 2011

\begin{tabular}{|c|c|}
\hline Methods & Prospective observational study \\
\hline \multirow[t]{7}{*}{ Participants } & $\begin{array}{l}\text { Inclusion criteria: clinically + laboratory-confirmed } \mathrm{BU} \text {; at least } 5 \text { years of age, presented with lesions } \leq \\
10 \mathrm{~cm} \text { in diameter that had appeared within the past } 6 \text { months, agreed to be hospitalized during treat- } \\
\text { ment, and were likely to be followed up for } 18 \text { months }\end{array}$ \\
\hline & $\begin{array}{l}\text { (exclusion criteria: multiple lesions, lesions located over a joint, history of treatment with antimycobac- } \\
\text { terial drugs, receipt of macrolide or quinolone antibiotics during the previous month, allergy to ri- } \\
\text { fampicin or clarithromycin, pregnancy, or HIV infection) }\end{array}$ \\
\hline & Laboratory confirmation: IS2404 dry-reagent-based PCR \\
\hline & Enrolled: 30 participants for analysis \\
\hline & Participant characteristics: 12 males, $40 \% ; 11$ were $>15$ years of age \\
\hline & Lesion types: ulcer 21 (47\%), non-ulcer 9 (30\%) \\
\hline & WHO category I: 13 (43\%), category II: 17 (57\%) \\
\hline
\end{tabular}


Chauty 2011 (Continued)
Interventions
Rifampicin (10 mg/kg/d) + clarithromycin (12 mg/kg/d), 8 weeks
Surgery: when indicated
Follow-up: participants were hospitalized during treatment for daily direct observation by nursing staff and were examined by a doctor every week. Swabs or aspiration samples were collected at week 4, 6, 8 if the lesion had not healed for culture and PCR. Participants were discharged from hospital when healed and were followed up every 3 months up to 18 months after start of treatment.

\begin{tabular}{ll}
\hline Outcomes & Wound healing at 12 months, without recurrence 18 months after initiation of antibiotics \\
2. Need of additional care to antibiotics (limited surgery, excision and skin grafting)
\end{tabular}

\section{Standarized outcome: cure}

$\begin{array}{ll}\text { Notes } & \text { Trial location: Benin } \\ & \text { Enrolment dates: December } 2007 \text { to February } 2009\end{array}$

\section{Risk of bias}

\begin{tabular}{|c|c|c|}
\hline Bias & Authors' judgement & Support for judgement \\
\hline $\begin{array}{l}\text { Random sequence genera- } \\
\text { tion (Trials) }\end{array}$ & High risk & - \\
\hline $\begin{array}{l}\text { Allocation concealment } \\
\text { (Trials) }\end{array}$ & High risk & - \\
\hline $\begin{array}{l}\text { Blinding of participants } \\
\text { and personnel (Trials) }\end{array}$ & High risk & - \\
\hline $\begin{array}{l}\text { Blinding of outcome as- } \\
\text { sessment (Trials) }\end{array}$ & High risk & - \\
\hline $\begin{array}{l}\text { Selection of participants } \\
\text { into the study (Prospective } \\
\text { observational studies) }\end{array}$ & High risk & $\begin{array}{l}2 / 3 \text { of eligible population refused participation due to refusal of hospitaliza- } \\
\text { tion. }\end{array}$ \\
\hline $\begin{array}{l}\text { Measurement of outcomes } \\
\text { (Prospective observational } \\
\text { studies) }\end{array}$ & Low risk & Objective outcome measure (healing) \\
\hline $\begin{array}{l}\text { Incomplete outcome da- } \\
\text { ta / missing data (All stud- } \\
\text { ies) }\end{array}$ & Low risk & No missing data \\
\hline $\begin{array}{l}\text { Selective reporting (All } \\
\text { studies) }\end{array}$ & Low risk & Reported all expected outcomes \\
\hline Other bias & Low risk & No other bias identified. \\
\hline
\end{tabular}

Espey 2002

\begin{tabular}{ll}
\hline Methods & Randomized controlled trial \\
\hline Participants & $\begin{array}{l}\text { Inclusion criteria: clinical diagnosis of } \mathrm{BU}^{\star} \text {; aged } 4 \text { years or older (excluded: history of TB, leprosy, HIV, } \\
\text { liver disease, pregnancy, breastfeeding) }\end{array}$ \\
\hline
\end{tabular}

Drugs for treating Buruli ulcer (Mycobacterium ulcerans disease) (Review) 
Case definition: the presence of a painless or minimally painful cutaneous ulcer with undermined margins

Enrolled: 41 participants; 10 participants were lost to follow-up, 1 pregnancy: 30 participants for analysis

Participant characteristics: intervention group 11 (73\%) males, median 13 years old (range, 5 to 60); control group 7 (47\%) males, median 10 years old (range, 5 to 60 )

Lesion types: ulcer 30 (100\%)

WHO category: N/A

Interventions

1. Dapsone ( 1.0 to $1.5 \mathrm{mg} / \mathrm{kg} /$ day) + rifampicin ( 10 to $20 \mathrm{mg} / \mathrm{kg} /$ day), 2 months

2. Placebo identical in appearance to dapsone, 2 months

Both groups received supportive local ulcer care consisting of cleansing and non-surgical debridement.

Surgery: none

Follow-up: 2 months; photographs were taken at enrolment and at 2 months for 28 participants

\begin{tabular}{ll}
\hline Outcomes & $\begin{array}{l}\text { 1. Clinical change, judged by photographs as "worse", "unchanged", or "improved", by } 2 \text { specialists } \\
\text { blinded to group }\end{array}$ \\
2. Change in ulcer size & 3. Adverse effects \\
\hline Notes & Trial location: Côte d'Ivoire \\
& Enrolment dates: 3 March to 4 April 1994 \\
& *Diagnostic tests: not all cases were confirmed as BU: $6 / 41(14.6 \%)$ skin biopsies were diagnostic of BU \\
(containing AFB or active necrosis of adipose tissue); $29(70.7 \%)$ were indicative of BU (granulomatous \\
changes and necrosis, without AFB); the remaining 3 revealed non-specific inflammation; 3/41 (7\%) \\
yielded positive cultures.
\end{tabular}

\section{Risk of bias}

\begin{tabular}{lll}
\hline Bias & Authors' judgement & Support for judgement \\
\hline $\begin{array}{l}\text { Random sequence genera- } \\
\text { tion (Trials) }\end{array}$ & Low risk & Quote: "Participants were randomized by lot to one of two groups." \\
\hline $\begin{array}{l}\text { Allocation concealment } \\
\text { (Trials) }\end{array}$ & Unclear risk & No information on allocation concealment \\
\hline $\begin{array}{l}\text { Blinding of participants } \\
\text { and personnel (Trials) }\end{array}$ & Low risk & $\begin{array}{l}\text { It does not seem that participants were blinded fully, as the placebo partici- } \\
\text { pants received only 1 pill, whereas the treatment group participants received } \\
\text { 2 pills. Investigators were also not blinded. However, outcome is probably un- } \\
\text { likely to be influenced by lack of blinding. }\end{array}$ \\
$\begin{array}{ll}\text { Blinding of outcome as- } \\
\text { sessment (Trials) }\end{array}$ & High risk & $\begin{array}{l}\text { Investigators not blinded to treatment status, and outcome is likely to have } \\
\text { been affected by lack of blinding. }\end{array}$ \\
\hline $\begin{array}{l}\text { Selection of participants } \\
\text { into the study (Prospective } \\
\text { observational studies) }\end{array}$ & Unclear risk & - \\
\hline
\end{tabular}


Espey 2002 (Continued)

Measurement of outcomes (Prospective observational studies)
Unclear risk

\begin{tabular}{|c|c|c|}
\hline $\begin{array}{l}\text { Incomplete outcome da- } \\
\text { ta / missing data (All stud- } \\
\text { ies) }\end{array}$ & High risk & $\begin{array}{l}10 \text { participants were lost to follow-up with no reasons provided. Given this } \\
\text { study's sample size, this is a relatively large amount of missing data. The } \\
\text { numbers in each group were initially balanced across treatment and placebo } \\
\text { groups. }\end{array}$ \\
\hline
\end{tabular}

\begin{tabular}{|c|c|c|}
\hline $\begin{array}{l}\text { Selective reporting (All } \\
\text { studies) }\end{array}$ & Low risk & Reported all expected outcomes \\
\hline \multirow{2}{*}{ Other bias } & & Photography outcome is prone to subjectivity. \\
\hline & & $\begin{array}{l}\text { A total of } 41 \text { skin biopsies from } 30 \text { enrolled participants were taken. } 3 / 30(10 \%) \\
\text { yielded no specific change compatible to } \mathrm{BU} \text {, indicating these cases may not } \\
\text { be BU. }\end{array}$ \\
\hline
\end{tabular}

\section{Etuaful 2005}

\begin{tabular}{ll}
\hline Methods & Randomized controlled trial \\
\hline Participants & $\begin{array}{l}\text { Inclusion criteria: clinically + laboratory-confirmed BU; had a single nodule or plaque } \leq 10 \mathrm{~cm} \text { in maxi- } \\
\text { mum diameter; aged } 15 \text { years or older (exclusion criteria: pregnancy, treatment with antibiotics, histo- } \\
\text { ry of leprosy, TB, liver, kidney, or hearing problems) }\end{array}$
\end{tabular}

Laboratory confirmation: either 1 or 2

1. Culture (+) or definite histopathology (the presence of Buruli-type coagulative necrosis of the dermis or subcuticular issue, with or without granulomas, and with or without AFB)

2. $\mathrm{PCR}(+)$ plus possible histopathology (the presence of panniculitis, with or without granulomas but without Buruli-type coagulative necrosis) or visible AFB

Enrolled: 33 participants; 1 participant withdrew, 1 excluded, 1 resolved completely during treatment, 9 participants did not meet final laboratory diagnosis; 21 participants for analysis

Participant characteristics: 7 male, 33\%; mean age N/A

Lesion types: 14 nodules, 7 plaques

WHO category: N/A fampicin $(10 \mathrm{mg} / \mathrm{kg} / \mathrm{d})+$ streptomycin $(15 \mathrm{mg} / \mathrm{kg} / \mathrm{d})$ given for 4 weeks, 8 weeks, 12 weeks before excision of the lesion.

Additional arm added during the study of rifampicin $(10 \mathrm{mg} / \mathrm{kg} / \mathrm{d})+\operatorname{streptomycin}(15 \mathrm{mg} / \mathrm{kg} / \mathrm{d}), 2$ weeks before excision of the lesion.

All participants were admitted to hospital for directly observed therapy.

Surgery: all cases

Follow-up period: 12 months after surgery 
Etuaful 2005 (Continued)

Outcomes
1. Change in mean surface areas of lesions before and after treatment with antibiotics for 2,4 , 8 , or 12 weeks

2. Recurrence

3. Adverse effects

$\begin{array}{ll}\text { Notes } & \text { Trial location: Ghana } \\ & \text { Enrolment dates: September } 2001 \text { to December } 2002\end{array}$

\section{Risk of bias}

\begin{tabular}{lll}
\hline Bias & Authors' judgement & Support for judgement \\
\hline $\begin{array}{l}\text { Random sequence genera- } \\
\text { tion (Trials) }\end{array}$ & High risk & $\begin{array}{l}\text { Participants in 4 groups (4 week, 8 week, 12 week, and surgery only) were ran- } \\
\text { domized using computer-generated numbers. Participants in } 2 \text { week treat- } \\
\text { ment group were recruited sequentially and were not randomized. }\end{array}$ \\
\hline
\end{tabular}

\begin{tabular}{lll}
\hline $\begin{array}{l}\text { Allocation concealment } \\
\text { (Trials) }\end{array}$ & Unclear risk & No information on allocation concealment \\
\hline $\begin{array}{l}\text { Blinding of participants } \\
\text { and personnel (Trials) }\end{array}$ & Low risk & $\begin{array}{l}\text { Blinding was not possible given different lengths of treatment and surgical in- } \\
\text { tervention, however outcome is unlikely to be influenced by lack of blinding. }\end{array}$ \\
\hline $\begin{array}{l}\text { Blinding of outcome as- } \\
\text { sessment (Trials) }\end{array}$ & Unclear risk & $\begin{array}{l}\text { No information on blinding of assessors, and outcome may be affected by lack } \\
\text { of blinding }\end{array}$ \\
\hline
\end{tabular}

$\begin{array}{ll}\text { Selection of participants } & \text { Unclear risk } \\ \text { into the study (Prospective } & \end{array}$

into the study (Prospective
observational studies)

Measurement of outcomes Unclear risk
(Prospective observational
studies)

Incomplete outcome da- Low risk

All 21 participants eligible for analysis in the study were analysed.
ta / missing data (All stud-
ies)

\begin{tabular}{lll}
\hline $\begin{array}{l}\text { Selective reporting (All } \\
\text { studies) }\end{array}$ & Low risk & Reported all expected outcomes \\
\hline Other bias & Low risk & No other bias identified. \\
\hline
\end{tabular}

Fehr 1994

\begin{tabular}{ll}
\hline Methods & Randomized controlled trial \\
\hline Participants & Inclusion criteria: clinically + laboratory-confirmed BU (exclusion criteria: none stated) \\
& Laboratory confirmation: diagnosis of BU was confirmed by ZN staining in 6 participants, culture in 4 \\
& participants, and histopathology in the remaining participants. \\
& Enrolled: 18 participants; 6 excluded from analysis due to lost to follow-up (4) and death (2); 12 partici- \\
pants for analysis
\end{tabular}


Fehr 1994 (Continued)

Participant characteristics: 5 male, 42\%; sulfamethoxazole/trimethoprim group: 18.3 years (5 to 32 ), placebo: 20.8 years ( 8 to 45 )

Lesion types: ulcer 12/12 (100\%)

1. $4 / 6(66 \%)$ in the sulfamethoxazole/trimethoprim and $2 / 6(33 \%)$ in the placebo group received surgery prior to intervention.

2. Initial ulcer size was 73.8 (9 to 247 ) $\mathrm{cm}^{2}$ for the sulfamethoxazole/trimethoprim and 38.7 (15 to 80 ) $\mathrm{cm}^{2}$ for the placebo group.

Interventions

1. Sulfamethoxazole/trimethoprim ( $800 \mathrm{mg}$ sulfamethoxazole/160 mg trimethoprim) 1 tablet twice daily for participants above 12 years; 0.5 tablet twice daily for younger participants

2. Identical placebo

Surgery: when indicated

Follow-up: follow-up was done by standardized examination including photographic documentation of ulcer size by the same observer up to 5 times in approximately 2-weekly intervals.

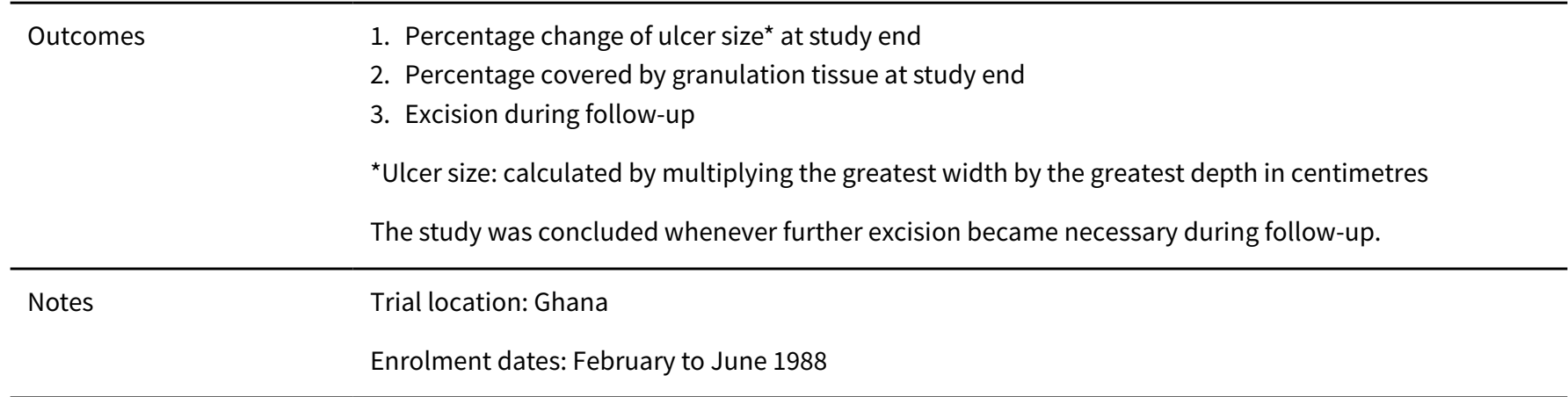

\section{Risk of bias}

\begin{tabular}{|c|c|c|}
\hline Bias & Authors' judgement & Support for judgement \\
\hline $\begin{array}{l}\text { Random sequence genera- } \\
\text { tion (Trials) }\end{array}$ & High risk & Used alternate allocation method \\
\hline $\begin{array}{l}\text { Allocation concealment } \\
\text { (Trials) }\end{array}$ & Unclear risk & $\begin{array}{l}\text { Unclear statement: "Patients were, in double-blinded fashion, alternately allo- } \\
\text { cated to Batrium forte or identical placebo." }\end{array}$ \\
\hline $\begin{array}{l}\text { Blinding of participants } \\
\text { and personnel (Trials) }\end{array}$ & Low risk & Identical placebo was used. \\
\hline $\begin{array}{l}\text { Blinding of outcome as- } \\
\text { sessment (Trials) }\end{array}$ & Unclear risk & $\begin{array}{l}\text { Not explicitly stated that the outcome assessor was blinded, though outcome } \\
\text { was assessed by } 1 \text { individual. }\end{array}$ \\
\hline $\begin{array}{l}\text { Selection of participants } \\
\text { into the study (Prospective } \\
\text { observational studies) }\end{array}$ & Unclear risk & - \\
\hline $\begin{array}{l}\text { Measurement of outcomes } \\
\text { (Prospective observational } \\
\text { studies) }\end{array}$ & Unclear risk & - \\
\hline $\begin{array}{l}\text { Incomplete outcome da- } \\
\text { ta / missing data (All stud- } \\
\text { ies) }\end{array}$ & Low risk & $\begin{array}{l}\text { Proportion of missing data is relatively large considering the sample size. How- } \\
\text { ever, reasons for exclusions/missing data are relatively well balanced or un- } \\
\text { likely to be related to true outcome. }\end{array}$ \\
\hline
\end{tabular}


Fehr 1994 (Continued)

\begin{tabular}{l}
$\begin{array}{l}\text { Selective reporting (All Low risk } \\
\text { studies) }\end{array}$ Reported all expected outcomes \\
\hline
\end{tabular}

Other bias

High risk

Baseline characteristics are not well balanced. No significant differences, but the groups are so small the $P$ values would not detect significant differences.

Friedman 2016

\begin{tabular}{|c|c|}
\hline Methods & Prospective observational study \\
\hline \multirow[t]{8}{*}{ Participants } & $\begin{array}{l}\text { Inclusion criteria: clinically + laboratory confirmed; treated with antimicrobials alone or with limited } \\
\text { surgical debridement* (excluded: those who underwent extensive surgery }{ }^{\star \star} \text { ) }\end{array}$ \\
\hline & $\begin{array}{l}{ }^{*} \text { Curettage of the lesion or a minor excision to remove excess granulation tissue and to debride ulcer } \\
\text { margins, with or without use of a split skin graft }\end{array}$ \\
\hline & $\begin{array}{l}{ }^{\star *} \text { Complete excision of the entire lesion including margins of non-necrotic tissue, with either direct clo- } \\
\text { sure or the use of a split skin graft or a vascularized skin and tissue flap for reconstruction or to cover } \\
\text { the defect }\end{array}$ \\
\hline & $\begin{array}{l}\text { Laboratory confirmation: any of (1) a culture of Mycobacterium ulcerans from the lesion, (2) PCR(+), or } \\
\text { (3) histopathology showing a necrotic granulomatous ulcer with the presence of AFB }\end{array}$ \\
\hline & $\begin{array}{l}\text { Enrolled: } 160 \text { participants; } 28 \text { underwent extensive surgery and were excluded; } 132 \text { participants for } \\
\text { analysis }\end{array}$ \\
\hline & Participant characteristics: 75 males, 56.8\%; median age 49 years (range, 1 to 95) \\
\hline & Lesion types: ulcer 110 (83.3\%), nodule 9 (6.8\%), oedema 10 (7.6\%), plaque $3(2.3 \%)$ \\
\hline & WHO category I: 104 (78.8\%), category II: 19 (14.4\%), category III: 9 (6.8\%) \\
\hline
\end{tabular}

Interventions

Antibiotics alone or antibiotics with limited surgical debridement

Included regimens:

Rifampicin $(10 \mathrm{mg} / \mathrm{kg} / \mathrm{d})$ plus

- Ciprofloxacin (500 mg twice daily)

- Clarithromycin (500 mg twice daily; 7.5 to $15 \mathrm{mg} / \mathrm{kg} /$ daily in divided doses in children)

- Moxifloxacin (400 mg daily)

Surgery: when indicated

Follow-up: 12 months

Outcomes

1. Treatment success defined as complete healing of the M ulcerans lesion without recurrence within 12 months of treatment commencement (cure)

2. Recurrence

3. Treatment failure

4. Adverse effects

5. Paradoxical reactions

6. Duration of antibiotic administration

$\begin{array}{ll}\text { Notes } & \text { Trial location: Australia } \\ & \text { Enrolment dates: } 1 \text { October } 2010 \text { to } 31 \text { December } 2014\end{array}$

Drugs for treating Buruli ulcer (Mycobacterium ulcerans disease) (Review) 
Friedman 2016 (Continued)

13/132 participants (9.5\%) had diabetes mellitus.

\section{Risk of bias}

\begin{tabular}{lll}
\hline Bias & Authors' judgement & Support for judgement \\
\hline $\begin{array}{l}\text { Random sequence genera- } \\
\text { tion (Trials) }\end{array}$ & High risk & - \\
\hline
\end{tabular}

Allocation concealment High risk
(Trials)

Blinding of participants $\quad$ High risk
and personnel (Trials)

\begin{tabular}{ll}
\hline $\begin{array}{l}\text { Blinding of outcome as- } \\
\text { sessment (Trials) }\end{array}$ & High risk \\
\hline
\end{tabular}

Selection of participants Low risk

All patients who met the study inclusion criteria were included. into the study (Prospective observational studies)

\begin{tabular}{ll}
\hline $\begin{array}{l}\text { Measurement of outcomes Low risk } \\
\text { (Prospective observational }\end{array}$ & Objective outcome measure (healing)
\end{tabular}
studies)

\begin{tabular}{lll}
\hline $\begin{array}{l}\text { Incomplete outcome da- } \\
\text { ta / missing data (All stud- } \\
\text { ies) }\end{array}$ & Low risk & No missing data \\
\hline $\begin{array}{l}\text { Selective reporting (All } \\
\text { studies) }\end{array}$ & Low risk & Reported all expected outcomes \\
\hline Other bias & Unclear risk & $\begin{array}{l}\text { 9.5\% of participants had comorbidities that may have affected healing rate } \\
\text { and time. }\end{array}$ \\
\hline
\end{tabular}

\section{Kibadi 2010}

\begin{tabular}{ll}
\hline Methods & Prospective observational study \\
\hline Participants & $\begin{array}{l}\text { Inclusion criteria: clinically diagnosed BU; ulcerative lesions with maximum diameter } \geq 10 \mathrm{~cm} ; 3 \text { to } 75 \\
\text { years old; residence in an endemic area (exclusion criteria: previous treatment by rifampicin or strep- } \\
\text { tomycin; previous diagnosis of leprosy or TB; pregnancy; presence of cardiovascular, hepatic, or renal } \\
\text { disease) }\end{array}$ \\
& $\begin{array}{l}\text { Enrolled: } 94 \text { participants; } 1 \text { refusal, } 1 \text { lost to follow-up; } 92 \text { participants for analysis } \\
\text { Participant characteristics: } 43 \text { males, } 47 \% ; 38 \text { participants } \leq 15 \text { years, } 43 \text { participants } 15 \text { to } 49 \text { years, } 11 \\
\text { participants } \geq 50 \text { years } \\
\text { Lesion types: ulcer } 92 \text { participants (100\%) } \\
\text { WHO category II: } 90 \text { participants (97.8\%), category III: } 2 \text { participants (2.2\%) } \\
\text { Rifampicin (10 mg/kg/d) + streptomycin (15 mg/kg/d) for } 12 \text { weeks, with surgery after the first } 4 \text { weeks } \\
\text { Local treatment was applied daily with an aqueous solution of chloramine-metronidazole-nitrofuran- } \\
\text { doine. }\end{array}$ \\
\hline Interventions
\end{tabular}


Kibadi 2010 (Continued)

\section{Surgery: all cases}

Follow-up period: follow-up evaluation was carried out at the end of the 4 th and 12 th week of treatment. Recurrence was followed up for at least 2 years after treatment completion.

Outcomes

1. Clinical outcome: "success" (4th week: $10 \%$ to $30 \%$ reduction in ulcer size and/or absence of new necrotic tissue, 12th week: healed), "clinical status quo" (no change in the size or presence of necrotic tissue), or "failure" (increase in the size and presence of new necrotic tissue)

2. Recurrence: reappearance of an ulcer or another form of the disease (nodule, papule, plaque, oedema, or bone involvement) at the original site of the lesion or elsewhere

\section{Standardized outcome: cure}

Trial location: Democratic Republic of Congo
Enrolment dates: October 2006 to September 2007
Clinical outcome was compared between $\mathrm{PCR}(+)$ and $\mathrm{PCR}(-)$ participants.
$\mathrm{PCR}(+): 61$ participants
$\mathrm{PCR}(-): 31$ participants

\section{Risk of bias}

\section{Bias}

Authors' judgement Support for judgement

Random sequence genera- High risk
tion (Trials)

\begin{tabular}{lll}
\hline $\begin{array}{l}\text { Allocation concealment } \\
\text { (Trials) }\end{array}$ & High risk & - \\
\hline $\begin{array}{l}\text { Blinding of participants } \\
\text { and personnel (Trials) }\end{array}$ & High risk & - \\
\hline
\end{tabular}

Blinding of outcome as- High risk
sessment (Trials)

\begin{tabular}{|c|c|c|}
\hline $\begin{array}{l}\text { Selection of participants } \\
\text { into the study (Prospective } \\
\text { observational studies) }\end{array}$ & Low risk & Selection not related to intervention or outcome. \\
\hline $\begin{array}{l}\text { Measurement of outcomes } \\
\text { (Prospective observational } \\
\text { studies) }\end{array}$ & Low risk & Objective outcome measure (healing) \\
\hline $\begin{array}{l}\text { Incomplete outcome da- } \\
\text { ta / missing data (All stud- } \\
\text { ies) }\end{array}$ & Low risk & 1 lost to follow-up, 1 death \\
\hline $\begin{array}{l}\text { Selective reporting (All } \\
\text { studies) }\end{array}$ & Low risk & Reported all expected outcomes \\
\hline Other bias & High risk & PCR-negative cases (30 participants, $33 \%$ ) may not be BU. \\
\hline
\end{tabular}


Lunn 1964

\begin{tabular}{|c|c|}
\hline Methods & Prospective observational study \\
\hline \multirow[t]{5}{*}{ Participants } & $\begin{array}{l}\text { Inclusion criteria: individuals with proved mycobacterial ulceration who presented themselves for } \\
\text { treatment (exclusion criteria: none stated) }\end{array}$ \\
\hline & Enrolled: 10 participants \\
\hline & Participant characteristics: 6 males, $60 \%$; median age 12.7 years (range, 6 to 20 ) \\
\hline & Lesion type: ulcers 10/10 (100\%) \\
\hline & WHO category: N/A \\
\hline \multirow[t]{5}{*}{ Interventions } & $\begin{array}{l}\text { B.663 (riminophenazine derivative; currently, clofazimine) was given as part of preparation for opera- } \\
\text { tion for } 1 \text { to } 4 \text { weeks and continued after operation until healing. }\end{array}$ \\
\hline & Adults > $50 \mathrm{~kg}: 300 \mathrm{mg} / \mathrm{day}$ \\
\hline & Adults 25 to $50 \mathrm{~kg}$, children: $200 \mathrm{mg} /$ day \\
\hline & Surgery: all cases \\
\hline & Follow-up: not specified \\
\hline
\end{tabular}

\begin{tabular}{ll}
\hline Outcomes & Healing \\
& Standarized outcome: possible cure \\
\hline Notes & Trial location: Uganda \\
& Enrolment dates: none stated. \\
\hline
\end{tabular}

\section{Risk of bias}

\begin{tabular}{lll}
\hline Bias & Authors' judgement & Support for judgement \\
\hline $\begin{array}{l}\text { Random sequence genera- } \\
\text { tion (Trials) }\end{array}$ & High risk & - \\
\hline $\begin{array}{l}\text { Allocation concealment } \\
\text { (Trials) }\end{array}$ & High risk & - \\
\hline $\begin{array}{l}\text { Blinding of participants } \\
\text { and personnel (Trials) }\end{array}$ & High risk & - \\
\hline $\begin{array}{l}\text { Blinding of outcome as- } \\
\text { sessment (Trials) }\end{array}$ & High risk & \\
\hline $\begin{array}{l}\text { Selection of participants } \\
\text { into the study (Prospective } \\
\text { observational studies) }\end{array}$ & Low risk & Selection not related to intervention or outcome. \\
\hline $\begin{array}{l}\text { Measurement of outcomes } \\
\begin{array}{l}\text { (Prospective observational } \\
\text { studies) }\end{array}\end{array}$ & Low risk & Objective outcome measure (healing) \\
\hline $\begin{array}{l}\text { Incomplete outcome da- } \\
\text { ta / missing data (All stud- } \\
\text { ies) }\end{array}$ & Unclear risk & $\begin{array}{l}\text { Not clear at what time point participants were assessed and whether they had } \\
\text { data for all 10 participants at a given time point }\end{array}$ \\
\hline
\end{tabular}


Lunn 1964 (Continued)

$\begin{aligned} & \text { Selective reporting (All Unclear risk } \\ & \text { studies) }\end{aligned}$
No predefined outcomes

Other bias Unclear risk No laboratory confirmation

O'Brien 2012

\begin{tabular}{|c|c|}
\hline Methods & Prospective observational study \\
\hline \multirow[t]{6}{*}{ Participants } & $\begin{array}{l}\text { Inclusion criteria: clinically + laboratory-confirmed BU; managed with surgery (exclusion criteria: none } \\
\text { stated) }\end{array}$ \\
\hline & $\begin{array}{l}\text { Laboratory confirmation: any of (1) a culture of Mycobacterium ulcerans from the lesion, (2) PCR(+), or } \\
\text { (3) histopathology showing a necrotic granulomatous ulcer with the presence of AFB. }\end{array}$ \\
\hline & $\begin{array}{l}\text { Enrolled: } 147 \text { participants; } 1 \text { without surgery, } 2 \text { deaths, } 1 \text { lost to follow-up, } 10 \text { ongoing treatment were } \\
\text { excluded; } 137 \text { lesions of } 133 \text { participants analysed }\end{array}$ \\
\hline & Participant characteristics: 67 males, 50.4\%; median age 62 years (range, 3 to 94) \\
\hline & $\begin{array}{l}\text { Lesion types: clinical type of lesion was recorded in 122/133 participants (92\%); ulcer } 106 \text { (87\%), nod- } \\
\text { ules } 9(7 \%) \text {, oedematous lesion } 7(6 \%) \text {. }\end{array}$ \\
\hline & WHO classification: N/A \\
\hline
\end{tabular}

Interventions

Surgery with or without different oral antibiotic treatments

90 participants received antibiotics as follows.

- Rifampicin + ciprofloxacin (55 participants, $61 \%$ )

- Rifampicin + clarithromycin (21 participants, $23 \%$ )

- Rifampicin + clarithromycin, and ethambutol (5 participants, $4 \%$ )

- Ciprofloxacin + clarithromycin (4 participants, $4 \%$ )

- Rifampicin + moxifloxacin (2 participants, $2 \%$ )

- Clarithromycin + ethambutol (1 participant, 1\%)

- Rifampicin + ethambutol, and amikacin (1 participant, 1\%)

- Clarithromycin only (1 participant, $1 \%)$

Drug dosages:

- Rifamipicin $10 \mathrm{mg} / \mathrm{kg} /$ day (up to a maximum of $600 \mathrm{mg} /$ day)

- Ciprofloxacin $500 \mathrm{mg}$ twice daily

- Clarithromycin 500 mg twice daily

- Moxifloxacin $400 \mathrm{mg}$ daily

- Amikacin $15 \mathrm{mg} / \mathrm{kg} /$ day

- Ethambutol not given

Surgery: all cases

Follow-up: 12 months

Outcomes

1. Treatment success, defined as complete healing of the $M$ ulcerans lesion without recurrence within 12 months of treatment commencement (cure)

2. Recurrence

3. Antibiotic duration prior to surgery

4. Adverse effects 
O'Brien 2012 (Continued)

5. Paradoxical reactions

Notes

Trial location: Australia

Enrolment dates: March 1998 to May 2010

11 participants were complicated with diabetes mellitus, 5 with malignancy, 4 with connective tissue disease, and 4 with immunosuppressive treatment.

\section{Risk of bias}

\begin{tabular}{|c|c|c|}
\hline Bias & Authors' judgement & Support for judgement \\
\hline $\begin{array}{l}\text { Random sequence genera- } \\
\text { tion (Trials) }\end{array}$ & High risk & - \\
\hline $\begin{array}{l}\text { Allocation concealment } \\
\text { (Trials) }\end{array}$ & High risk & - \\
\hline $\begin{array}{l}\text { Blinding of participants } \\
\text { and personnel (Trials) }\end{array}$ & High risk & - \\
\hline $\begin{array}{l}\text { Blinding of outcome as- } \\
\text { sessment (Trials) }\end{array}$ & High risk & - \\
\hline $\begin{array}{l}\text { Selection of participants } \\
\text { into the study (Prospective } \\
\text { observational studies) }\end{array}$ & High risk & $\begin{array}{l}\text { Small numbers lost to follow-up, but } 10 \text { were excluded because treatment was } \\
\text { ongoing, therefore selection related to outcome present. }\end{array}$ \\
\hline $\begin{array}{l}\text { Measurement of outcomes } \\
\text { (Prospective observational } \\
\text { studies) }\end{array}$ & Low risk & Outcomes were objective. \\
\hline $\begin{array}{l}\text { Incomplete outcome da- } \\
\text { ta / missing data (All stud- } \\
\text { ies) }\end{array}$ & Low risk & No missing data \\
\hline $\begin{array}{l}\text { Selective reporting (All } \\
\text { studies) }\end{array}$ & Low risk & Reported all expected outcomes \\
\hline Other bias & High risk & $\begin{array}{l}\text { The proportion of participants receiving antibiotic treatment increased from } \\
2005 \text {; there might be important differences between groups especially be- } \\
\text { fore this time. Study not really able to detect differences between treatment + } \\
\text { surgery and surgery alone. } 24 / 133(18 \%) \text { of participants had comorbidities that } \\
\text { may have affected healing. }\end{array}$ \\
\hline
\end{tabular}

\section{O'Brien 2013b}

\begin{tabular}{|c|c|}
\hline Methods & Prospective observational study \\
\hline \multirow[t]{3}{*}{ Participants } & $\begin{array}{l}\text { Inclusion criteria: clinically + laboratory-confirmed BU; received antibiotics with or without surgery (ex- } \\
\text { clusion criteria: none stated) }\end{array}$ \\
\hline & $\begin{array}{l}\text { Laboratory confirmation: any of (1) a culture of Mycobacterium ulcerans from the lesion, (2) PCR(+), or } \\
\text { (3) histopathology showing a necrotic granulomatous ulcer with the presence of AFB }\end{array}$ \\
\hline & Enrolled: 160 participants; 2 deaths, 2 lost to follow-up; 156 participants analysed \\
\hline
\end{tabular}


O'Brien 2013b (Continued)

Participant characteristics: 86 males, 55.1\%; 13 participants $(8.3 \%)<15$ years, 62 participants $(39.7 \%)$

15 to 59 years, 81 participants $(51.9 \%)>60$ years

Lesion types: ulcer 137 (87.8\%), nodules 10 (6.4\%), oedematous lesion 9 (5.8\%)

WHO classification: N/A

Interventions

Different oral antibiotic treatments.

Participants received combinations of the following.

- Rifampicin 147 (94.2\%)

- Ciprofloxacin 101 (64.7\%)

- Clarithromycin 48 (30.8\%)

- Ethambutol 11 (7.1\%)

- Amikacin $5(3.2 \%)$

- Moxifloxacin $2(1.5 \%)$

Drug dosages

- Rifamipicin $10 \mathrm{mg} / \mathrm{kg} /$ day (up to a maximum of $600 \mathrm{mg} /$ day)

- Ciprofloxacin $500 \mathrm{mg}$ twice daily

- Clarithromycin $7.5 \mathrm{mg} / \mathrm{kg} / \mathrm{twice}$ daily (up to maximum of $500 \mathrm{mg}$ twice daily)

- Moxifloxacin $400 \mathrm{mg}$ daily

- Amikacin $15 \mathrm{mg} / \mathrm{kg} /$ day

Surgery: when indicated

Follow-up: at least 12 months

Outcomes
1. Episodes of paradoxical reactions
2. Lesion site
3. Diagnosis and treatment
4. Healing of paradoxical reactions
5. Predictors of paradoxical reactions

Notes

Trial location: Australia

Enrolment dates: 1 January 1998 to 31 December 2011

$13(8.3 \%)$ participants were complicated with diabetes mellitus and $11(7.1 \%)$ with immune suppression (defined as current treatment with immunosuppressive medication (for example, prednisolone) or an active malignancy).

\section{Risk of bias}

\begin{tabular}{lll}
\hline Bias & Authors' judgement & Support for judgement \\
\hline $\begin{array}{l}\text { Random sequence genera- } \\
\text { tion (Trials) }\end{array}$ & High risk & - \\
\hline $\begin{array}{l}\text { Allocation concealment } \\
\text { (Trials) }\end{array}$ & High risk & - \\
\hline $\begin{array}{l}\text { Blinding of participants } \\
\text { and personnel (Trials) }\end{array}$ & High risk & - \\
\hline $\begin{array}{l}\text { Blinding of outcome as- } \\
\text { sessment (Trials) }\end{array}$ & High risk & - \\
\hline \hline
\end{tabular}

Drugs for treating Buruli ulcer (Mycobacterium ulcerans disease) (Review) 
O'Brien 2013b (Continued)

Selection of participants Low risk Small number (4) not included as did not have 12 months follow-up or had into the study (Prospective died.

observational studies)

Measurement of outcomes Low risk Paradoxical reaction clearly defined.
(Prospective observational

studies)

Incomplete outcome da- Low risk No missing data
ta / missing data (All stud-

ta / missing data (All stud-

ies)

$\begin{aligned} & \text { Selective reporting (All Low risk } \quad \text { Reported all expected outcomes } \\ & \text { studies) }\end{aligned}$

Other bias Low risk No other bias identified.

\section{Phillips 2014a}

\begin{tabular}{|c|c|}
\hline Methods & Prospective observational study \\
\hline \multirow[t]{7}{*}{ Participants } & $\begin{array}{l}\text { Inclusion criteria: clinically + laboratory-confirmed BU; at least } 5 \text { years of age, presented with lesions } \leq \\
15 \mathrm{~cm} \text { in diameter }\end{array}$ \\
\hline & $\begin{array}{l}\text { (exclusion criteria: tuberculosis or leprosy; renal or hepatic impairment, auditory problems; under } \\
\text { treatment with antibiotics or herbal preparations; pregnancy) }\end{array}$ \\
\hline & Laboratory confirmation: IS2404 dry-reagent-based PCR \\
\hline & $\begin{array}{l}\text { Enrolled: } 82 \text { patients screened for BU; } 17 \text { not meeting clinical and or epidemiological criteria for BU, } 18 \\
\text { large category III lesions, } 1 \text { pregnancy, } 3 \text { were below } 5 \text { years; } 43 \text { for analysis }\end{array}$ \\
\hline & Participant characteristics: 18 males, $42 \%$; median age 15 (range, 5 to 70 ) \\
\hline & Lesion types: ulcer 20 (47\%), nodules 14 (32\%), plaque $9(21 \%)$ \\
\hline & WHO category I: 27 (63\%), category II: 12 (28\%), category III: 4 (9\%) \\
\hline
\end{tabular}

Interventions $\quad$ Rifampicin $(10 \mathrm{mg} / \mathrm{kg} / \mathrm{d})+$ streptomycin $(15 \mathrm{mg} / \mathrm{kg} / \mathrm{d}), 2$ weeks followed by rifampicin $(10 \mathrm{mg} / \mathrm{kg} / \mathrm{d})+$ clarithromycin $(7.5 \mathrm{mg} / \mathrm{kg} / \mathrm{d}), 6$ weeks

The treatment was administered under the direct observation of village health workers.

Surgery: when indicated; surgery and skin grafting was offered to participants whose lesion had enlarged during or after treatment by more than $150 \%$ of the initial size or had not healed by week 52 .

Follow-up: 52 weeks

Outcomes Healing of the Mycobacterium ulcerans lesion without recurrence within 12 months of treatment com-
mencement (cure)
2. Healing time
3. Recurrence
4. Adverse event (vestibulocochlear toxicity)
5. Paradoxical reactions

Notes

Trial location: Ghana

Drugs for treating Buruli ulcer (Mycobacterium ulcerans disease) (Review) 
Phillips 2014a (Continued)

Enrolment dates: July 2009 to July 2010

\section{Risk of bias}

\begin{tabular}{|c|c|c|}
\hline Bias & Authors' judgement & Support for judgement \\
\hline $\begin{array}{l}\text { Random sequence genera- } \\
\text { tion (Trials) }\end{array}$ & High risk & - \\
\hline $\begin{array}{l}\text { Allocation concealment } \\
\text { (Trials) }\end{array}$ & High risk & - \\
\hline $\begin{array}{l}\text { Blinding of participants } \\
\text { and personnel (Trials) }\end{array}$ & High risk & - \\
\hline $\begin{array}{l}\text { Blinding of outcome as- } \\
\text { sessment (Trials) }\end{array}$ & High risk & - \\
\hline $\begin{array}{l}\text { Selection of participants } \\
\text { into the study (Prospective } \\
\text { observational studies) }\end{array}$ & Low risk & Selection not related to intervention or outcome. \\
\hline $\begin{array}{l}\text { Measurement of outcomes } \\
\text { (Prospective observational } \\
\text { studies) }\end{array}$ & Low risk & Objective outcome measures \\
\hline $\begin{array}{l}\text { Incomplete outcome da- } \\
\text { ta / missing data (All stud- } \\
\text { ies) }\end{array}$ & Low risk & Only $2(5 \%)$ participants were lost to follow-up. \\
\hline $\begin{array}{l}\text { Selective reporting (All } \\
\text { studies) }\end{array}$ & Low risk & Reported all expected outcomes \\
\hline Other bias & Low risk & No other bias identified. \\
\hline
\end{tabular}

Revill 1973

\begin{tabular}{ll}
\hline Methods & Randomized controlled trial \\
\hline Participants & Inclusion criteria: clinically diagnosed BU (exclusion criteria: none stated) \\
& Laboratory confirmation: 22/105 (21\%) participants had positive cultures for Mycobacterium ulcerans. \\
& Enrolled: 106 participants; 1 excluded; 105 participants for analysis \\
& Participant characteristics: sex N/A; age N/A \\
& Lesion types: ulcer 34/105 (33\%) \\
& WHO category: N/A \\
\hline
\end{tabular}

Interventions

Participants were placed into 4 groups:

1. uncomplicated non-ulcerated lesions with immediate surgery withheld (Group A: 34 participants, $32.5 \%$ );

2. uncomplicated non-ulcerated lesions with immediate surgery (Group B: 16 participants, 15\%);

3. complicated non-ulcerated lesions with immediate surgery (Group C: 21 participants, 20\%); 
Revill 1973 (Continued)

4. ulcerated lesion with immediate surgery (Group D: 34 participants, $32.5 \%$ ).

They were randomized to the following groups.

1. Clofazimine (10 to $20 \mathrm{mg} / \mathrm{kg} /$ day) continued for at least 1 month after complete clinical healing ( 3 to 6 months)

2. Placebo capsule

Surgery: when indicated

Follow-up: participants were followed up every 2 weeks at a clinic in the trial area. Those who did not attend were visited at home. After the treatment period, participants were seen at approximately 3monthly intervals. The follow-up period ranged from 17 to 40 months (median of 32 months).

\begin{tabular}{ll}
\hline Outcomes & $\begin{array}{l}\text { 1. Healing } \\
\text { 2. Median healing time } \\
\text { 3. Recurrence } \\
\text { Standarized outcome: possible cure }\end{array}$ \\
\hline Notes & Trial location: Uganda \\
& Enrolment dates: July 1968 to March 1970
\end{tabular}

\section{Risk of bias}

\begin{tabular}{|c|c|c|}
\hline Bias & Authors' judgement & Support for judgement \\
\hline $\begin{array}{l}\text { Random sequence genera- } \\
\text { tion (Trials) }\end{array}$ & High risk & Only partial group was randomized. \\
\hline $\begin{array}{l}\text { Allocation concealment } \\
\text { (Trials) }\end{array}$ & Low risk & Allocation concealed from both participant and doctor. \\
\hline $\begin{array}{l}\text { Blinding of participants } \\
\text { and personnel (Trials) }\end{array}$ & Low risk & Placebo capsule was used, and both participant and doctor were blinded. \\
\hline $\begin{array}{l}\text { Blinding of outcome as- } \\
\text { sessment (Trials) }\end{array}$ & Unclear risk & No information about whether outcome assessors were blinded \\
\hline $\begin{array}{l}\text { Selection of participants } \\
\text { into the study (Prospective } \\
\text { observational studies) }\end{array}$ & Unclear risk & - \\
\hline $\begin{array}{l}\text { Measurement of outcomes } \\
\text { (Prospective observational } \\
\text { studies) }\end{array}$ & Unclear risk & - \\
\hline $\begin{array}{l}\text { Incomplete outcome da- } \\
\text { ta / missing data (All stud- } \\
\text { ies) }\end{array}$ & Low risk & $\begin{array}{l}\text { Only } 1 \text { participant missing, and reason explained and unlikely to affect out- } \\
\text { come. }\end{array}$ \\
\hline $\begin{array}{l}\text { Selective reporting (All } \\
\text { studies) }\end{array}$ & Low risk & Reported all expected outcomes \\
\hline Other bias & Low risk & No other bias identified. \\
\hline
\end{tabular}


Sarfo 2010

\begin{tabular}{|c|c|}
\hline Methods & Prospective observational study \\
\hline \multirow[t]{9}{*}{ Participants } & $\begin{array}{l}\text { Inclusion criteria: clinically + laboratory-confirmed BU (exclusion criteria: previous diagnosis of lep- } \\
\text { rosy or TB; presence of renal or hepatic impairment or auditory problems; treatment with antibiotics or } \\
\text { herbal preparations) }\end{array}$ \\
\hline & $\begin{array}{l}\text { Laboratory confirmation: diagnosis was confirmed by } 1 \text { or more methods. Swabs, punch biopsy speci- } \\
\text { men, or fine-needle aspirates were taken to test for the following. }\end{array}$ \\
\hline & 1. AFB \\
\hline & 2. Culture for Mycobacterium ulcerans \\
\hline & 3. PCR for IS2404 \\
\hline & $\begin{array}{l}\text { Enrolled: } 171 \text { participants; } 6 \text { participants with no diagnostic samples, } 5 \text { participants with negative labo- } \\
\text { ratory results; } 160 \text { participants for analysis }\end{array}$ \\
\hline & Participant characteristics: 66 males (41\%), median 12 years (range, 1 to 75 years) \\
\hline & Lesion types: ulcer 86 (53.7\%), nodule 36 (22.5\%), plaque 14 (8.8\%), oedema $24(15 \%)$ \\
\hline & WHO category I: 48 (30\%), category II: 56 (35\%), category III: 56 (35\%) \\
\hline \multirow[t]{3}{*}{ Interventions } & Rifampicin $(10 \mathrm{mg} / \mathrm{kg} / \mathrm{d})+$ streptomycin $(15 \mathrm{mg} / \mathrm{kg} / \mathrm{d})$ for 8 weeks \\
\hline & Surgery: when indicated \\
\hline & Follow-up period: 1 year after treatment completion \\
\hline \multirow[t]{6}{*}{ Outcomes } & $\begin{array}{l}\text { 1. Healing of the } M \text { ulcerans lesion without recurrence within } 12 \text { months of treatment commencement } \\
\text { (cure) }\end{array}$ \\
\hline & 2. Healing time \\
\hline & 3. Rate of healing of each measurable lesion \\
\hline & 4. Recurrence until 12 months \\
\hline & 5. Adverse effects \\
\hline & 6. Paradoxical reactions \\
\hline
\end{tabular}

Notes

Trial location: Ghana

Enrolment dates: September 2005 to December 2007

\section{Risk of bias}

\begin{tabular}{lll}
\hline Bias & Authors' judgement & Support for judgement \\
\hline $\begin{array}{l}\text { Random sequence genera- } \\
\text { tion (Trials) }\end{array}$ & High risk & - \\
\hline $\begin{array}{l}\text { Allocation concealment } \\
\text { (Trials) }\end{array}$ & High risk & - \\
\hline $\begin{array}{l}\text { Blinding of participants } \\
\text { and personnel (Trials) }\end{array}$ & High risk & - \\
\hline $\begin{array}{l}\text { Blinding of outcome as- } \\
\text { sessment (Trials) }\end{array}$ & High risk \\
\hline $\begin{array}{l}\text { Selection of participants } \\
\text { into the study (Prospective } \\
\text { observational studies) }\end{array}$ & Low risk & Selection not related to intervention or outcome. \\
\hline \hline
\end{tabular}

Drugs for treating Buruli ulcer (Mycobacterium ulcerans disease) (Review) 
Sarfo 2010 (Continued)
Measurement of outcomes
Low risk
Objective outcome measures
(Prospective observational studies)

\begin{tabular}{lll}
$\begin{array}{l}\text { Incomplete outcome da- } \\
\text { ta / missing data (All stud- } \\
\text { ies) }\end{array}$ & Low risk & 1 death and 1 lost to follow-up at 1 year \\
\hline $\begin{array}{l}\text { Selective reporting (All } \\
\text { studies) }\end{array}$ & Low risk & Reported all expected outcomes \\
\hline Other bias & Low risk & No other bias identified. \\
\hline & \\
$\begin{array}{l}\text { Abbreviations: AFB: acid-fast bacilli; BU: Buruli ulcer; IQR: interquartile range; N/A: not available; PCR: polymerase chain reaction; SD: } \\
\text { standard deviation; TB: tuberculosis; WHO: World Health Organization; ZN: Ziehl-Neelsen. }\end{array}$
\end{tabular}

Characteristics of excluded studies [ordered by study ID]

\begin{tabular}{|c|c|}
\hline Study & Reason for exclusion \\
\hline Addison 2015 & Conference proceeding \\
\hline Adjei 1998 & Wrong study design \\
\hline Adou 2009 & Review \\
\hline Adu 2011 & Wrong study design \\
\hline Adu 2015 & Wrong study design \\
\hline Aguiar 1997 & Wrong study design \\
\hline Alferink 2013 & Wrong study design \\
\hline Alffenaar 2010 & Duplicate \\
\hline Anonymous 2010 & Review \\
\hline Arens 2015 & Conference proceeding \\
\hline Azanmasso 2013 & Wrong outcomes \\
\hline Bamberger 2011 & Review \\
\hline Barogui 2009 & Wrong study design \\
\hline Barogui 2013 & Wrong study design \\
\hline Cornet 1992 & Wrong study design \\
\hline Cowan 2015 & Wrong study design \\
\hline Darie 1993 & Wrong study design \\
\hline de Bergeyck 1980 & Wrong study design \\
\hline
\end{tabular}

Drugs for treating Buruli ulcer (Mycobacterium ulcerans disease) (Review)

Copyright $\odot 2018$ The Authors. Cochrane Database of Systematic Reviews published by John Wiley \& Sons, Ltd. on behalf of The Cochrane

Collaboration. 


\begin{tabular}{|c|c|}
\hline Study & Reason for exclusion \\
\hline Debacker 2005 & Wrong study design \\
\hline Friedman 2012 & Wrong intervention \\
\hline Gordon 2010 & Wrong study design \\
\hline Guerra 2008 & Wrong study design \\
\hline Josse 1994 & Wrong study design \\
\hline Kanga 2003 & Wrong study design \\
\hline Kibadi 2007 & Wrong study design \\
\hline Klis 2014a & Duplicate \\
\hline Klis 2014b & Commentary \\
\hline Klis 2014c & Duplicate \\
\hline Klis 2014d & Commentary \\
\hline Klis 2016 & Wrong study design \\
\hline Kotey 2011 & Conference proceeding \\
\hline Lunn 1965 & Review \\
\hline Marion 2015 & Wrong study design \\
\hline Milánkovits 2010 & Commentary \\
\hline Mou 2015 & Wrong outcomes \\
\hline Nienhuis 2012 & Duplicate \\
\hline O'Brien 2014 & Wrong intervention \\
\hline Oluwasanmi 1975 & Wrong study design \\
\hline Pfau 2015 & Conference proceeding \\
\hline Phanzu 2006 & Wrong study design \\
\hline Phanzu 2011 & Wrong study design \\
\hline Phillips 2004 & Wrong intervention \\
\hline Phillips 2014b & Commentary \\
\hline Ruf 2011 & Wrong study design \\
\hline Ruf 2015 & Wrong intervention \\
\hline Saka 2013 & Wrong study design \\
\hline
\end{tabular}

Drugs for treating Buruli ulcer (Mycobacterium ulcerans disease) (Review) 


\begin{tabular}{ll}
\hline Study & Reason for exclusion \\
\hline Schunk 2009 & Wrong study design \\
\hline Schütte 2009 & Wrong setting \\
\hline Stienstra 2012 & Wrong study design \\
\hline Teelken 2003 & Wrong study design \\
\hline van der Werf 1989 & Wrong study design \\
\hline Vignier 2014 & Wrong study design \\
\hline Vuagnat 2011 & Wrong intervention \\
\hline Yeboah-Manu 2013 & Conference proceeding \\
\hline
\end{tabular}

Characteristics of ongoing studies [ordered by study ID]

\section{NCT01432925}

\begin{tabular}{|c|c|}
\hline Trial name or title & Timing of surgical intervention in Buruli ulcer patients treated with antibiotics (Burulitime) \\
\hline Methods & Randomized controlled trial (single-blind) \\
\hline \multirow[t]{3}{*}{ Participants } & $\begin{array}{l}\text { Inclusion criteria: aged } 3 \text { years and older, all stages of the BU disease with confirmation by direct } \\
\text { microscopy following acid-fast staining or PCR }\end{array}$ \\
\hline & $\begin{array}{l}\text { Exclusion criteria: patients not on the standard treatment of } 8 \text { weeks of rifampicin and strepto- } \\
\text { mycin for any reason, including non-compliant patients; treatment with macrolide or quinolone } \\
\text { antibiotics, or antituberculous medication, or immunomodulatory drugs including corticosteroids } \\
\text { within the previous } 1 \text { month; contraindication for general anaesthesia; pregnancy; osteomyelitis; } \\
\text { lesion close to the eye; refusal to surgery at any point in the intended treatment; HIV positive; lack } \\
\text { of willingness to give informed consent }\end{array}$ \\
\hline & Estimated enrolment: 260 \\
\hline
\end{tabular}

Interventions

1. Rifampicin $(10 \mathrm{mg} / \mathrm{kg} / \mathrm{d})+$ streptomycin $(15 \mathrm{mg} / \mathrm{kg} / \mathrm{d}), 8$ weeks plus surgery at week 8

2. Rifampicin $(10 \mathrm{mg} / \mathrm{kg} / \mathrm{d})+$ streptomycin $(15 \mathrm{mg} / \mathrm{kg} / \mathrm{d}), 8$ weeks plus surgery at week 14

\section{Outcomes}

\section{Primary outcome}

1. Healing without surgical intervention (time frame: 1 year)

Secondary outcomes

1. Extent of surgery by measurement of lesional size

2. Functional limitations after the end of treatment and 1 year after the start of treatment

3. Duration of admission

$\begin{array}{ll}\text { Starting date } & \text { September } 2011 \\ & \text { Anticipated end date: January } 2017\end{array}$

Ymkje Stienstra, MD PhD, University Medical Center Groningen

Notes Trial location: Benin

Drugs for treating Buruli ulcer (Mycobacterium ulcerans disease) (Review)

Copyright $\odot 2018$ The Authors. Cochrane Database of Systematic Reviews published by John Wiley \& Sons, Ltd. on behalf of The Cochrane

Collaboration. 
NCT01659437

Trial name or title Randomized controlled trial comparing efficacy of 8 weeks treatment with clarithromycin and rifampicin versus streptomycin and rifampicin for Buruli ulcer (Mycobacterium ulcerans infection)

Methods Randomized controlled trial (multicentre, open-label)

Participants

Inclusion criteria: aged 5 years and older, with a clinical diagnosis of BU disease (categories I and II, cross-sectional diameter $\leq 10 \mathrm{~cm}$ ) as agreed by study site treatment team led by the lead clinicians

Exclusion criteria: lesion sizes $>10 \mathrm{~cm}$ in cross-sectional diameter; children $<5$ years, or $<20$ kg body weight; pregnancy; previous treatment of Buruli ulcer, tuberculosis, or leprosy with at least 1 of the study drugs (rifampicin, streptomycin, clarithromycin); history of hypersensitivity to rifampicin and/or streptomycin and/or clarithromycin; previous treatment with macrolide or quinolone antibiotics, or antituberculosis medication, or immunomodulatory drugs including corticosteroids within 1 month; current treatment with any drugs likely to interact with the study medication; co-infection with HIV; history or having current clinical signs of ascites, jaundice, partial or complete deafness, myasthenia gravis, renal dysfunction (known or suspected), diabetes mellitus, and severe immune compromise (for example, immunosuppressive drugs after organ transplant), or evidence of (previous) tuberculosis, Buruli ulcer or leprosy, or terminal illness (for example, metastasized cancer); unable to take oral medication or having gastrointestinal disease likely to interfere with drug absorption; individuals with known or suspected bowel strictures who cannot tolerate macrolide antibiotics such as clarithromycin; mental condition likely to interfere with ability to comply with the study protocol

Estimated enrolment: 415

$\begin{array}{ll}\text { Interventions } & \text { 1. Rifampicin }(10 \mathrm{mg} / \mathrm{kg} / \mathrm{d})+\text { streptomycin }(15 \mathrm{mg} / \mathrm{kg} / \mathrm{d}), 8 \text { weeks } \\ \text { 2. Rifampicin }(10 \mathrm{mg} / \mathrm{kg} / \mathrm{d})+\text { clarithromycin }(7.5 \mathrm{mg} / \mathrm{kg} / \mathrm{d}), 8 \text { weeks }\end{array}$

\section{Outcomes}

\section{Primary outcome}

1. Healing without recurrence and without excision surgery (time frame: 12 months after start of treatment)

\section{Secondary outcomes}

1. Recurrence rate within 12 months of treatment initiation

2. Number of recurrent lesions occurring after initial healing within 12 months of treatment initiation

3. Rate of treatment failure within 12 months of treatment initiation

4. Rate of paradoxical response within 12 months of treatment initiation

5. Proportion of participants with reduction in lesion surface area within 12 months of treatment initiation

6. Time taken for complete lesion healing within 12 months of treatment initiation

7. Proportion (\%) of participants with complete healing without additional surgery or relapse

8. Interval between healing and recurrence

9. Proportion of each type of surgery within 12 months of treatment initiation

10.Time from treatment initiation to surgery if any

11.Proportion of participants with residual functional limitations

12.Treatment discontinuation and compliance rates

13.Incidence of all adverse effects within 12 months of treatment initiation 
NCT01659437 (Continued)

Anticipated end date: January 2018

Contact information

Tjip S van der Werf, Professor, University Medical Center Groningen (t.s.van.der.werf@umcg.nl)

Notes

Trial location: 1 centre in Benin and 4 centres in Ghana

Registration number: NCT01659437

Abbreviations: BU: Buruli ulcer; PCR: polymerase chain reaction

\section{DATA AND ANALYSES}

Comparison 1. Rifampicin combined with streptomycin versus surgery alone

\begin{tabular}{lllll}
\hline Outcome or subgroup title & No. of studies & $\begin{array}{l}\text { No. of partici- } \\
\text { pants }\end{array}$ & Statistical method & Effect size \\
\hline 1 Recurrence & 1 & 21 & Risk Ratio (M-H, Fixed, 95\% Cl) & $0.12[0.01,2.51]$ \\
\hline
\end{tabular}

\section{Analysis 1.1. Comparison 1 Rifampicin combined with streptomycin versus surgery alone, Outcome 1 Recurrence.}

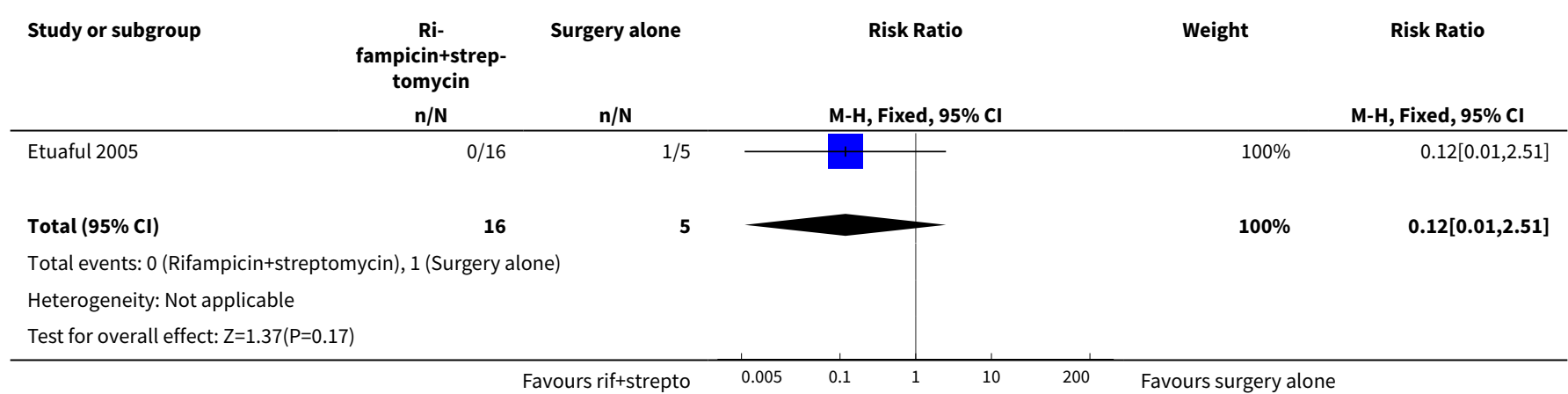

Comparison 2. Rifampicin combined with clarithromycin versus rifampicin combined with streptomycin in the consolidation phase

\begin{tabular}{lllll}
\hline $\begin{array}{l}\text { Outcome or subgroup ti- } \\
\text { tle }\end{array}$ & No. of studies & $\begin{array}{l}\text { No. of partici- } \\
\text { pants }\end{array}$ & Statistical method & Effect size \\
\hline 1 Cure & 1 & 151 & Risk Ratio (M-H, Fixed, 95\% Cl) & $0.94[0.87,1.03]$ \\
\hline 2 Recurrence at 12 months & 1 & 151 & Risk Ratio (M-H, Fixed, 95\% Cl) & $0.0[0.0,0.0]$ \\
\hline
\end{tabular}


Analysis 2.1. Comparison 2 Rifampicin combined with clarithromycin versus rifampicin combined with streptomycin in the consolidation phase, Outcome 1 Cure.

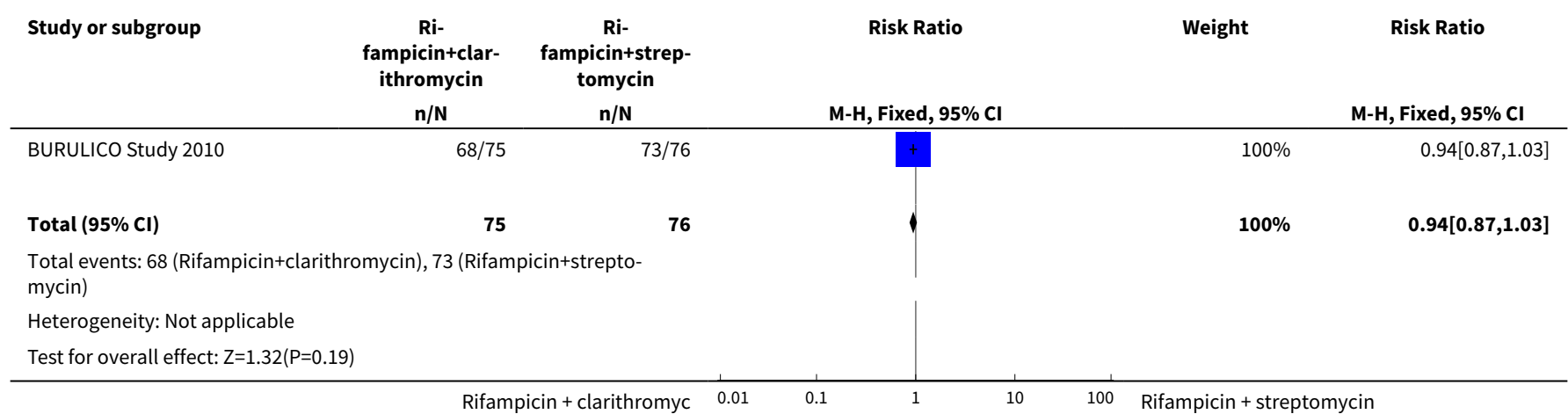

Analysis 2.2. Comparison 2 Rifampicin combined with clarithromycin versus rifampicin combined with streptomycin in the consolidation phase, Outcome 2 Recurrence at 12 months.

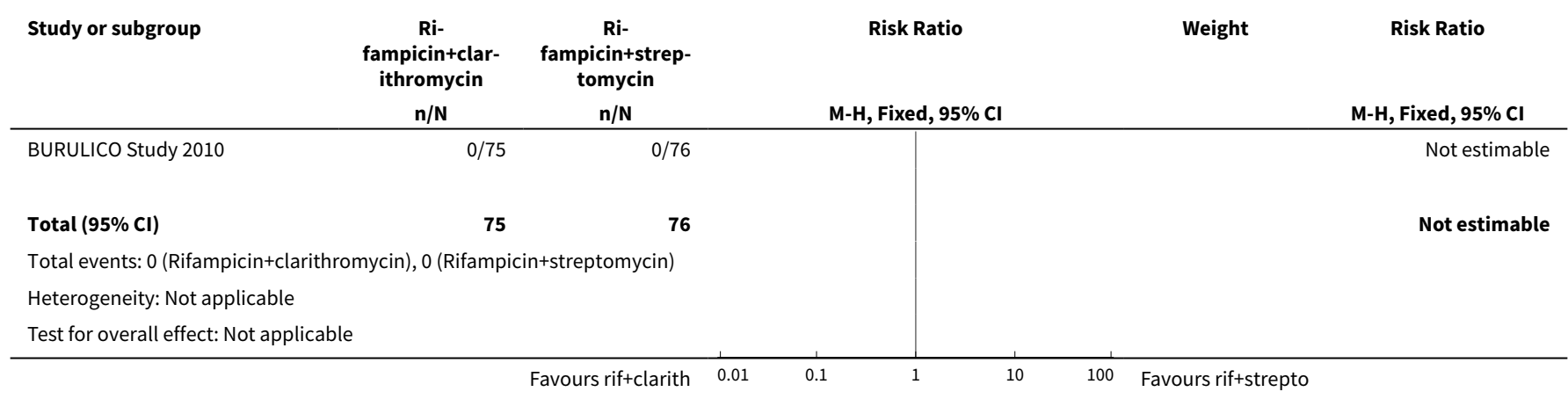




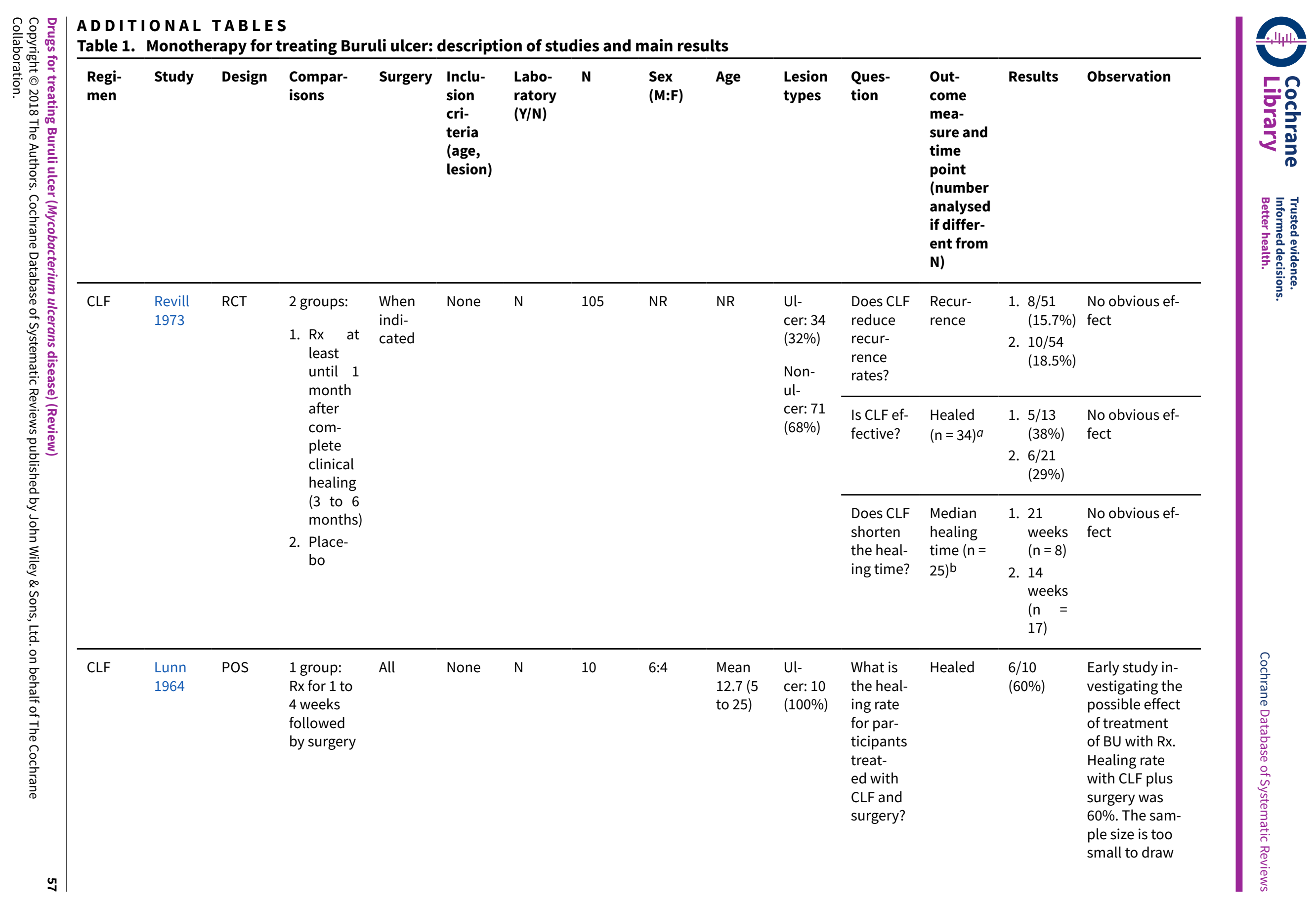




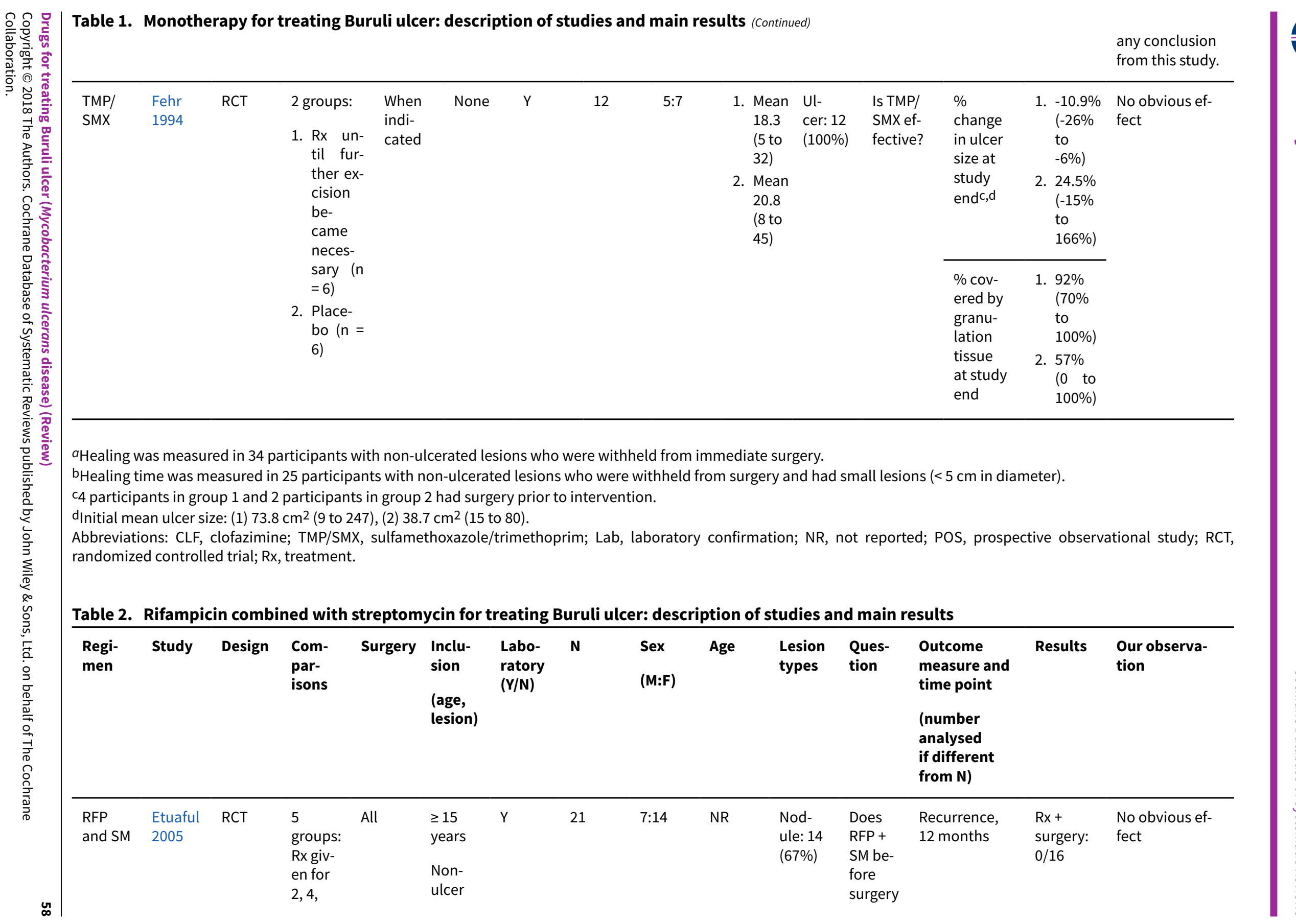




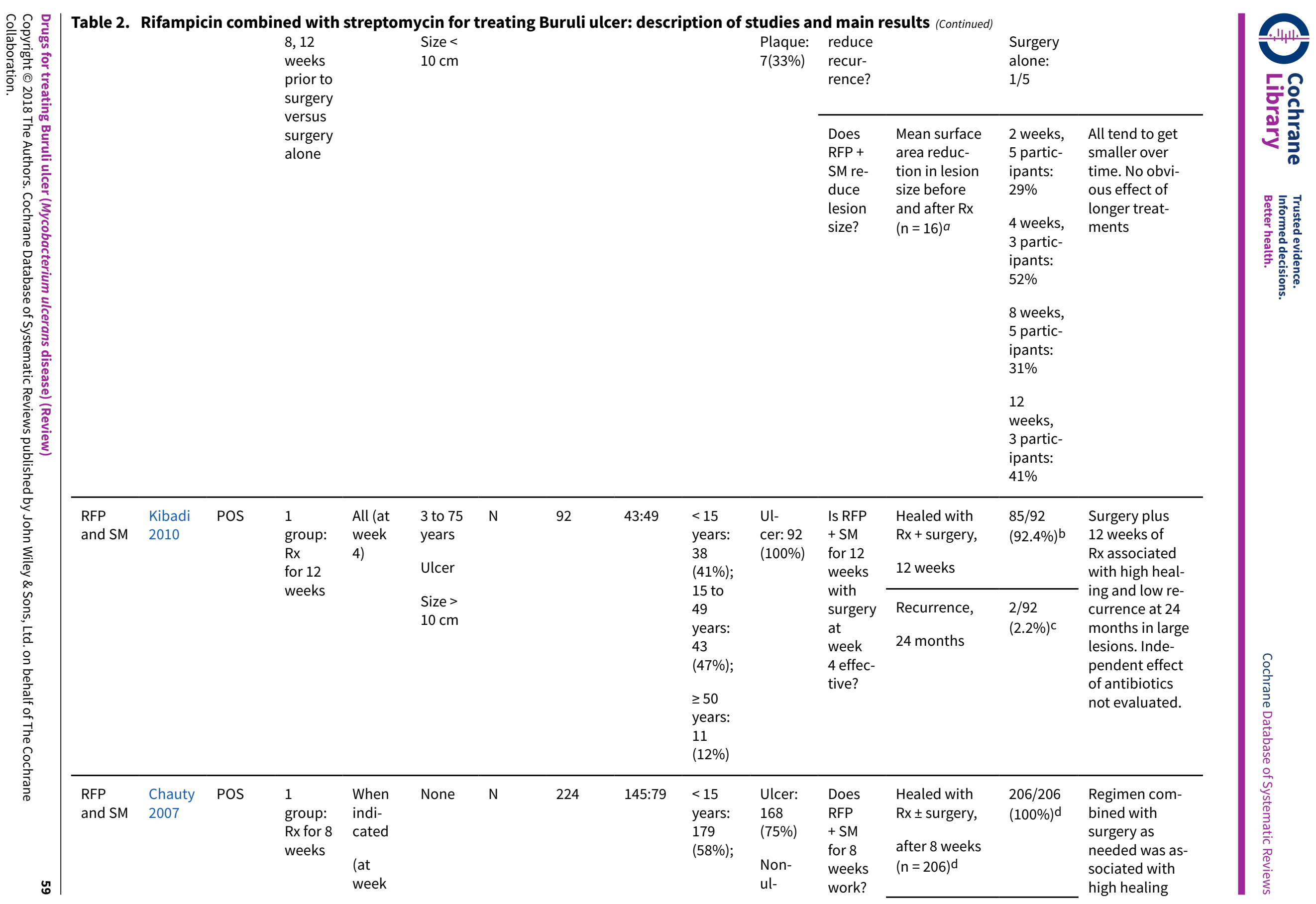




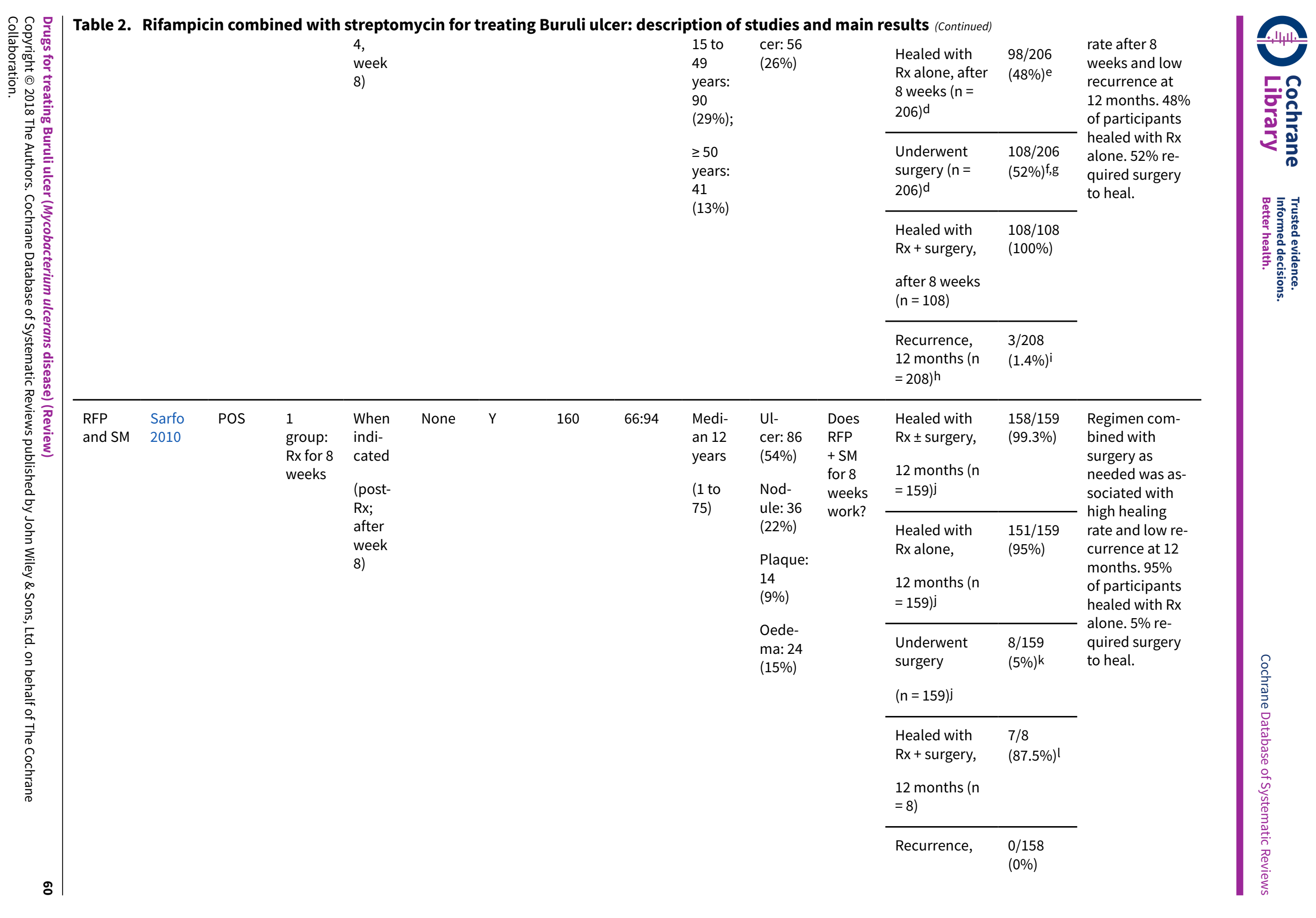




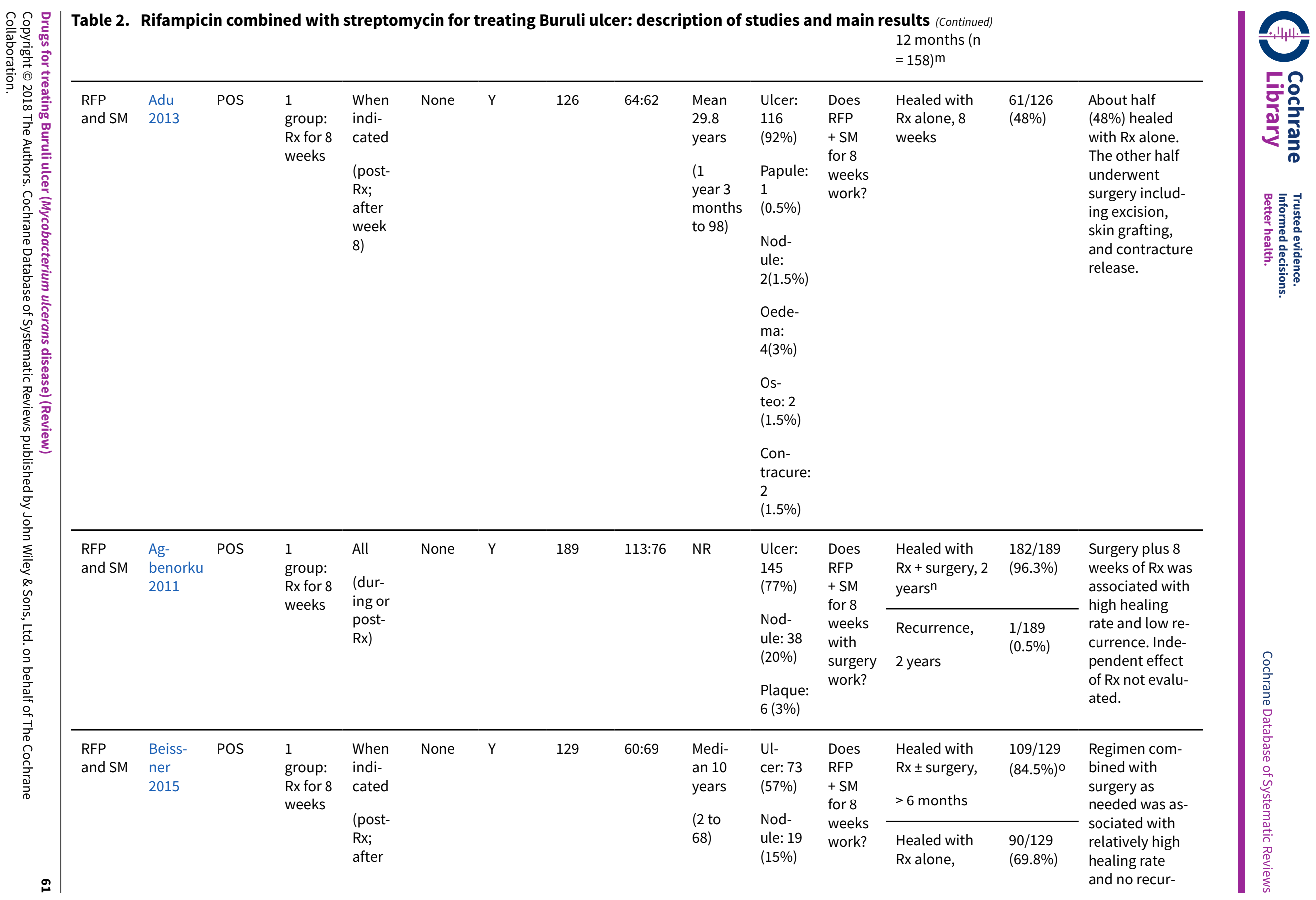


Table 2. Rifampicin combined with streptomycin for treating Buruli ulcer: description of studies and main results (Continued)

week

8)
Plaque:

26

$(20 \%)$

Oede-

ma: 11

(8\%)
$>6$ months

\begin{tabular}{ll}
\hline Underwent & $35 / 129$ \\
surgery, & $(27 \%)$ \\
$>6$ months &
\end{tabular}

Healed with

Rx + surgery,

$19 / 35$

(54\%)

6 months $(\mathrm{n}=$

35) rence at minimum 6 months. $70 \%$ of partic-

ipants healed with Rx alone. $27 \%$ of par-

ticipants re-

quired surgery,

of which 54\%

healed.

Recurrence,

None

$>6$ months

$a_{16}$ participants who received Rx plus surgery were analysed. Participant characteristics for this group were: M:F = 6:10; age: NR; lesion types: nodule, 11 (69\%), plaque, 5 ( $\left.31 \%\right)$. bPCR(+) group, 60/61 (98.4\%); PCR(-) group, 25/30 (83.3\%).

c2/61(3.3\%) among PCR(+) group.

d 17 lost to follow-up; 1 death.

eUlcer size < 5 cm, 22/98 (22.5\%); ulcer size 5 to 14 cm, 40/98 (41\%); ulcer size >= 15 cm, 12/98 (12\%); non-ulcer, 24/98 (24.5\%).

fulcer size < 5 cm, 5/108 (4.6\%); ulcer size 5 to 14 cm, 27/108 (25\%); ulcer size >= 15 cm, 46/108 (42.6\%); non-ulcer, 30/108 (27.8\%).

gDecision to perform surgery was made by a treating physician: immediate upon enrolment, 4/108 (3.7\%); 4-week assessment, 83/108 (76.9\%); 8-week assessment, 21/108 $(19.4 \%)$.

h208 participants were retrieved for 1-year follow-up.

i2 among the Rx-only group; 1 among the Rx + surgery group.

j1 death.

k2 participants with nodules, 1 participant with plaque, 5 participants with ulcerated oedematous lesions, and 2 participants with large ulcers were offered surgical intervention after 8 weeks of Rx; 8 accepted surgery.

11 participant evaluated as treatment failure in this review although successful treatment at 1 year follow-up. The participant received additional 4 weeks of RFP + SM (a total of 12 weeks) with breaking down of skin grafting with culture positive during course of treatment.

m158 participants were retrieved for 1-year follow-up after treatment completion.

nDebridement and skin grafting included as surgery: 38 participants (20.1\%) with nodules or plaque excised, 151 participants with ulcers (79.9\%) had debridement and skin grafting.

05 participants $(3.9 \%)$ had secondary lesions, and 15 participants $(11.6 \%)$ had functional limitations.

Abbreviations: Lab, laboratory confirmation; NR, not reported; Osteo, osteomyelitis; POS, prospective observational study; RCT, randomized controlled trial; RFP, rifampicin; Rx, treatment; SM, streptomycin. 


\begin{tabular}{|c|c|c|c|c|c|c|c|c|c|c|c|c|c|c|}
\hline $\begin{array}{l}\text { Regi- } \\
\text { men }\end{array}$ & Study & Design & $\begin{array}{l}\text { Compar- } \\
\text { isons }\end{array}$ & Surgery & $\begin{array}{l}\text { Inclu- } \\
\text { sion } \\
\text { (age, } \\
\text { lesion) }\end{array}$ & $\begin{array}{l}\text { Labo- } \\
\text { ratory } \\
(\mathrm{Y} / \mathrm{N})\end{array}$ & $\mathbf{N}$ & $\begin{array}{l}\text { Sex } \\
\text { (M:F) }\end{array}$ & Age & $\begin{array}{l}\text { Lesion } \\
\text { types }\end{array}$ & $\begin{array}{l}\text { Ques- } \\
\text { tion }\end{array}$ & $\begin{array}{l}\text { Outcome } \\
\text { measure } \\
\text { and time } \\
\text { point (num- } \\
\text { ber if differ- } \\
\text { ent from } N \text { ) }\end{array}$ & $\begin{array}{l}\text { Re- } \\
\text { sults }\end{array}$ & Our observation \\
\hline \multirow[t]{5}{*}{$\begin{array}{l}\text { RFP } \\
\text { and } \\
\text { CAM }\end{array}$} & \multirow[t]{5}{*}{$\begin{array}{l}\text { Chauty } \\
2011\end{array}$} & \multirow[t]{5}{*}{ POS } & \multirow[t]{5}{*}{$\begin{array}{l}1 \text { group: } \\
\text { Rx giv- } \\
\text { en for } 8 \\
\text { weeks }\end{array}$} & \multirow[t]{5}{*}{$\begin{array}{l}\text { When } \\
\text { indi- } \\
\text { cated }\end{array}$} & \multirow{5}{*}{$\begin{array}{l}\geq 5 \\
\text { years } \\
\text { Size } \leq \\
10 \mathrm{~cm}\end{array}$} & \multirow[t]{5}{*}{$\mathrm{Y}$} & \multirow[t]{5}{*}{30} & \multirow[t]{5}{*}{$18: 12$} & \multirow[t]{5}{*}{ NR } & \multirow{5}{*}{$\begin{array}{l}\text { Ul- } \\
\text { cer: } 21 \\
\text { (70\%) } \\
\text { Non- } \\
\text { ulcer: } 9 \\
(30 \%)\end{array}$} & \multirow{5}{*}{$\begin{array}{l}\text { Does } 8 \\
\text { weeks } \\
\text { of RFP } \\
+ \text { CAM } \\
\text { work? }\end{array}$} & $\begin{array}{l}\text { Healed with } \\
\mathrm{Rx} \pm \text { surgery, } \\
12 \text { months }\end{array}$ & $\begin{array}{l}30 / 30 \\
(100 \%)\end{array}$ & \multirow{5}{*}{$\begin{array}{l}\text { Regimen com- } \\
\text { bined with } \\
\text { surgery as need- } \\
\text { ed was associ- } \\
\text { ated with high } \\
\text { healing rate at } \\
12 \text { months and } \\
\text { no recurrence } \\
\text { at } 18 \text { months in } \\
\text { participants with } \\
\text { small lesions. } \\
50 \% \text { of partici- } \\
\text { pants healed with } \\
\text { Rx alone. } 50 \% \text { re- } \\
\text { quired surgery to } \\
\text { heal. }\end{array}$} \\
\hline & & & & & & & & & & & & $\begin{array}{l}\text { Healed with } \\
\text { Rx alone, } 12 \\
\text { months }\end{array}$ & $\begin{array}{l}15 / 30 \\
(50 \%)^{a}\end{array}$ & \\
\hline & & & & & & & & & & & & $\begin{array}{l}\text { Underwent } \\
\text { surgery, } 12 \\
\text { months }\end{array}$ & $\begin{array}{l}15 / 30 \\
(50 \%)\end{array}$ & \\
\hline & & & & & & & & & & & & $\begin{array}{l}\text { Healed with } \\
\text { Rx + surgery, } \\
12 \text { months } \\
(n=15)\end{array}$ & $\begin{array}{l}15 / 15 \\
(100 \%)^{b}\end{array}$ & \\
\hline & & & & & & & & & & & & $\begin{array}{l}\text { Recurrence, } \\
18 \text { months }\end{array}$ & None & \\
\hline \multirow[t]{2}{*}{$\begin{array}{l}\text { RFP } \\
\text { and } \\
\text { CAM }\end{array}$} & \multirow[t]{2}{*}{$\begin{array}{l}\text { O'Brien } \\
2012\end{array}$} & \multirow[t]{2}{*}{ POS } & \multirow{2}{*}{$\begin{array}{l}1 \text { group: } \\
\text { Rx, du- } \\
\text { ration } \\
\text { depend- } \\
\text { ing up- } \\
\text { on physi- } \\
\text { cian's } \\
\text { decision }\end{array}$} & \multirow[t]{2}{*}{ All } & \multirow[t]{2}{*}{ None } & \multirow[t]{2}{*}{$\mathrm{Y}$} & \multirow[t]{2}{*}{21} & \multirow[t]{2}{*}{ NR } & \multirow[t]{2}{*}{ NR } & \multirow[t]{2}{*}{ NR } & \multirow{2}{*}{$\begin{array}{l}\text { Does } \\
\text { RFP + } \\
\text { CAM } \\
\text { plus } \\
\text { surgery } \\
\text { work? }\end{array}$} & $\begin{array}{l}\text { Healed with } \\
\text { Rx + surgery, } \\
12 \text { months }\end{array}$ & $\begin{array}{l}21 / 21 \\
(100 \%)\end{array}$ & \multirow{2}{*}{$\begin{array}{l}\text { Surgery plus Rx } \\
\text { was associated } \\
\text { with high heal- } \\
\text { ing rate and no } \\
\text { recurrence at } 12 \\
\text { months. Indepen- } \\
\text { dent effect of an- } \\
\text { tibiotics not eval- } \\
\text { uated. Duration } \\
\text { of Rx varied. }\end{array}$} \\
\hline & & & & & & & & & & & & $\begin{array}{l}\text { Recurrence, } \\
12 \text { months }\end{array}$ & None & \\
\hline $\begin{array}{l}\text { RFP } \\
\text { and SM } \\
\text { plus }\end{array}$ & $\begin{array}{l}\text { BU- } \\
\text { RULI- } \\
\text { CO } \\
\text { Study } \\
2010\end{array}$ & $\mathrm{RCT}$ & $\begin{array}{l}2 \\
\text { groups: } \\
\text { 1. RFP + } \\
\text { SM for } \\
4\end{array}$ & $\begin{array}{l}\text { When } \\
\text { indi- } \\
\text { cated }\end{array}$ & $\begin{array}{l}\geq 5 \\
\text { years } \\
\text { Size } \leq \\
10 \mathrm{~cm}\end{array}$ & $\mathrm{Y}$ & 151 & $46: 105$ & $\begin{array}{l}\text { 1. Me- } \\
\text { di- } \\
\text { an } \\
12 \\
\text { years } \\
\text { (IQR }\end{array}$ & $\begin{array}{l}\text { Ul- } \\
\text { cer: } 59 \\
(39 \%) \\
\text { Non- } \\
\text { ul- }\end{array}$ & $\begin{array}{l}\text { Can } \\
\text { RFP + } \\
\text { CAM } \\
\text { substi- } \\
\text { tute for }\end{array}$ & $\begin{array}{l}\text { Healed with } \\
\text { Rx alone or } \\
\text { Rx + skin } \\
\text { grafting, } 12 \\
\text { months }\end{array}$ & $\begin{array}{l}\text { 1. } 68 / 75 \\
(91 \%) \\
\text { 2. } 73 / 76 \\
(96 \%)^{c}\end{array}$ & $\begin{array}{l}\text { 4RS + 4RC was } \\
\text { as effective as } \\
8 \mathrm{RS} \text { in partici- } \\
\text {,pants with small } \\
\text { lesions. Both reg- } \\
\text { imens were asso- }\end{array}$ \\
\hline
\end{tabular}




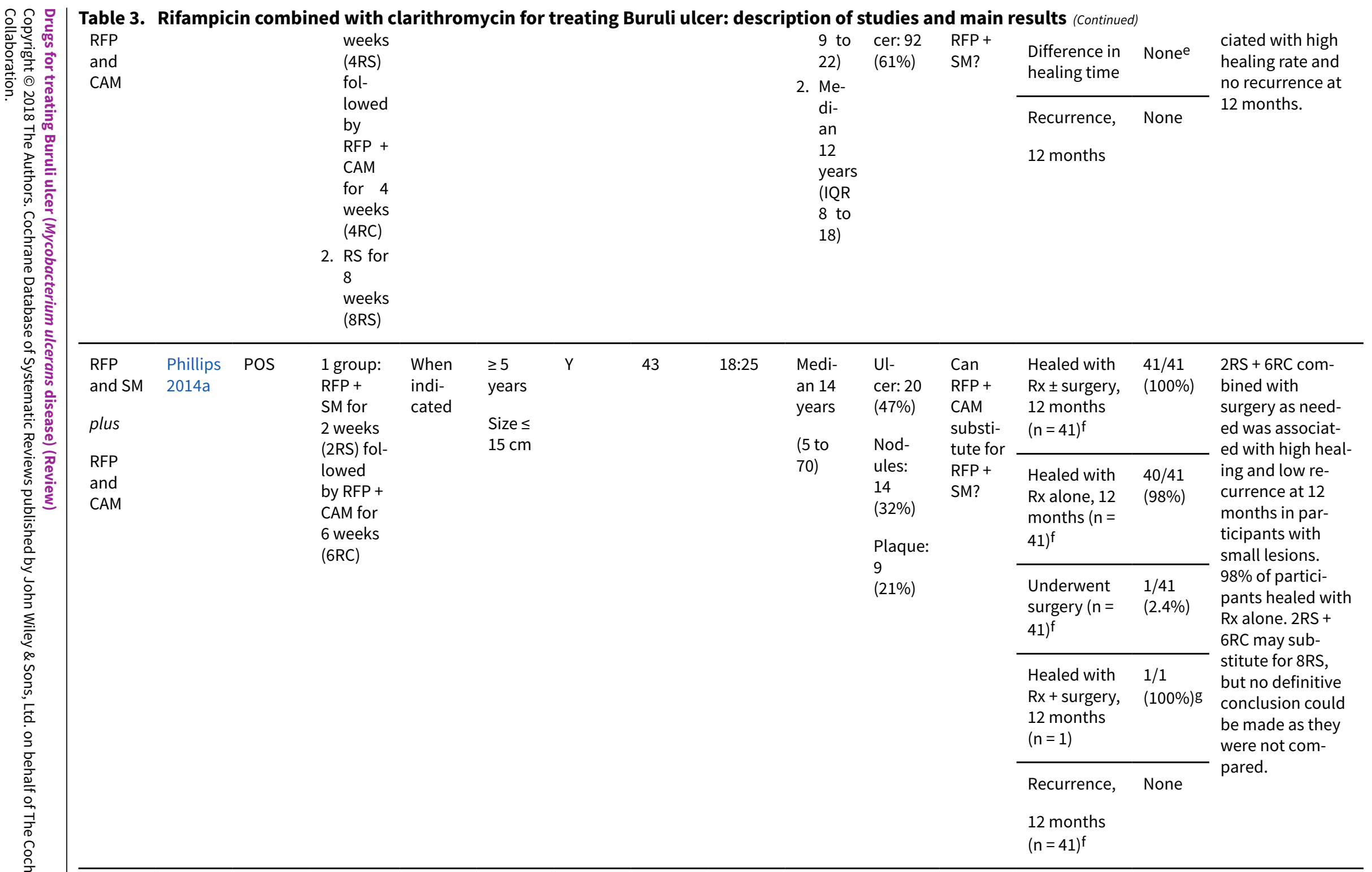

a8/10 (80\%) with ulcerative-WHO category I lesion; 5/11 (45\%) with ulcerative-WHO category II lesion; 2/3 (66\%) with non-ulcerative-WHO category I lesion; 0/6 (0\%) with nonulcerative-WHO category II lesion.

$b_{11}(37 \%)$ with limited surgery; $4(13 \%)$ with excision and skin grafting.

cSkin grafting without excision: (1) 1/75 (1.3\%); (2) 4/76 (5.3\%). 


\begin{tabular}{|c|c|c|c|c|c|c|c|c|c|c|c|c|c|c|}
\hline \multirow{4}{*}{ 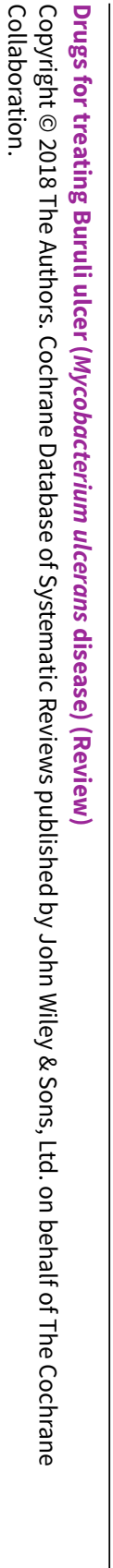 } & \multicolumn{14}{|c|}{$\begin{array}{l}\text { dOdds ratio } 2.49,95 \% \text { confidence interval } 0.66 \text { to infinity; } P=0.16 \text {, } 1 \text {-sided Fisher's exact test. } \\
\text { eGroup proportional hazard model: } P=0.26 ; 99 \% \text { confidence interval } 0.22 \text { to } 0.29 \text {; generalized Wilcoxon-Mann-Whitney test: } P=0.60 ; 99 \% \text { confidence interval } 0.56 \text { to } 0.64 \text {. } \\
\text { f2 lost to follow-up. } \\
\text { gSkin grafting at week } 32 \text {. } \\
\text { Abbreviations: CAM, clarithromycin; IQR, interquartile range; Lab, laboratory confirmation; NR, not reported; POS, prospective observational study; RCT, randomized controlled } \\
\text { trial; RFP, rifampicin; Rx, treatment; SM, streptomycin. }\end{array}$} \\
\hline & Study & Design & $\begin{array}{l}\text { Compari- } \\
\text { son(s) }\end{array}$ & Surgery & $\begin{array}{l}\begin{array}{l}\text { Inclu- } \\
\text { sion }\end{array} \\
\text { (age, } \\
\text { lesion) }\end{array}$ & $\begin{array}{l}\text { Labo- } \\
\text { ratory } \\
(\mathrm{Y} / \mathrm{N})\end{array}$ & $\mathbf{N}$ & $\begin{array}{l}\text { Sex } \\
\text { (M:F) }\end{array}$ & Age & $\begin{array}{l}\text { Lesion } \\
\text { types }\end{array}$ & $\begin{array}{l}\text { Ques- } \\
\text { tion }\end{array}$ & $\begin{array}{l}\text { Out- } \\
\text { come } \\
\text { mea- } \\
\text { sure and } \\
\text { time } \\
\text { point } \\
\text { (number } \\
\text { if differ- } \\
\text { ent from } \\
\mathrm{N} \text { ) }\end{array}$ & $\begin{array}{l}\text { Re- } \\
\text { sults }\end{array}$ & Our observation \\
\hline & \multirow[t]{2}{*}{$\begin{array}{l}\text { Espey } \\
2002\end{array}$} & \multirow[t]{2}{*}{$\mathrm{RCT}$} & \multirow[t]{2}{*}{$\begin{array}{l}\text { 2 groups: } \\
\text { 1. Rx for } \\
8 \text { weeks } \\
(\mathrm{n}=15) \\
\text { 2. Place- } \\
\text { bo ( } \mathrm{n}= \\
15)\end{array}$} & \multirow[t]{2}{*}{ None } & \multirow[t]{2}{*}{$\begin{array}{l}>4 \\
\text { years } \\
\text { Ulcer }\end{array}$} & \multirow[t]{2}{*}{$\mathrm{N}$} & \multirow[t]{2}{*}{30} & \multirow[t]{2}{*}{ 18:12 } & \multirow[t]{2}{*}{$N R$} & \multirow[t]{2}{*}{$\begin{array}{l}\text { Ul- } \\
\text { cer: } 30 \\
(100 \%)\end{array}$} & \multirow[t]{2}{*}{$\begin{array}{l}\text { Is RFP } \\
+ \text { DDS } \\
\text { effec- } \\
\text { tive? }\end{array}$} & $\begin{array}{l}\text { Im- } \\
\text { proved } \\
\text { after } 2 \\
\text { months } \\
(\mathrm{n}=28)^{a}\end{array}$ & $\begin{array}{ll}\text { 1. } & 82 \% \\
& (23 / 28 \\
\text { points }) \\
\text { 2. } & 75 \% \\
(21 / 28 \\
\text { points })\end{array}$ & \multirow[t]{2}{*}{$\begin{array}{l}\text { Unable to assess } \\
8 \text { the effect due to } \\
\text { s) incongruent char- } \\
\text { acteristics at base- } \\
8 \text { line, however there } \\
\text { s) } \text { lseems to be no ob- }^{\text {vious effect. }}\end{array}$} \\
\hline & & & & & & & & & & & & $\begin{array}{l}\text { Change } \\
\text { in ul- } \\
\text { cer size } \\
\text { after } 2 \\
\text { months }\end{array}$ & $\begin{array}{l}\text { 1. } 14.0 \\
\mathrm{~cm}^{2} \\
\text { de- } \\
\text { crease } \\
\text { (range, } \\
3.8 \\
\text { to } \\
-159.0) \\
\text { 2. } 2.5 \\
\mathrm{~cm}^{2} \\
\text { de- } \\
\text { crease } \\
\text { (range, } \\
78.0 \\
\text { to } \\
-35.0) \mathrm{c}\end{array}$ & \\
\hline
\end{tabular}




\begin{tabular}{|c|c|c|c|c|c|c|c|c|c|c|c|c|c|c|}
\hline \multirow[t]{5}{*}{$\begin{array}{l}\text { RFP } \\
\text { and ei- } \\
\text { ther } \\
\text { CIPRO, } \\
\text { CAM, } \\
\text { or MOX }\end{array}$} & \multirow[t]{5}{*}{$\begin{array}{l}\text { Fried- } \\
\text { man } \\
2016\end{array}$} & \multirow[t]{5}{*}{ POS } & \multirow[t]{5}{*}{$\begin{array}{l}\text { 3 groups: } \\
\text { 1. RFP + } \\
\text { CIPRO } \\
\text { (n=80) } \\
\text { 2. RFP + } \\
\text { CAM (n } \\
=50) \\
\text { 3. RFP + } \\
\text { MOX (n } \\
=2)\end{array}$} & \multirow{5}{*}{$\begin{array}{l}\text { Lim- } \\
\text { ited } \\
\text { surgi- } \\
\text { cal de- } \\
\text { bride- } \\
\text { ment } \\
\text { when } \\
\text { indi- } \\
\text { catedd } \\
\text { (exten- } \\
\text { sive } \\
\text { surgi- } \\
\text { cal ex- } \\
\text { cisions } \\
\text { exclud- } \\
\text { ed) }\end{array}$} & \multirow[t]{5}{*}{ Non } & \multirow[t]{5}{*}{$Y$} & \multirow[t]{5}{*}{132} & \multirow[t]{5}{*}{$75: 57$} & \multirow[t]{5}{*}{$\begin{array}{l}\text { Medi- } \\
\text { an } 49 \\
\text { years } \\
\text { (1 to } \\
95)\end{array}$} & \multirow{5}{*}{$\begin{array}{l}\text { Ulcer: } \\
110 \\
(83.3 \%) \\
\\
\text { Nod- } \\
\text { ule: } 9 \\
(6.8 \%) \\
\text { Oede- } \\
\text { ma: } 10 \\
(7.6 \%) \\
\text { Plaque: } \\
3 \\
(2.3 \%)\end{array}$} & \multirow{5}{*}{$\begin{array}{l}\text { Does } \\
\text { RFP- } \\
\text { based } \\
\text { all-oral } \\
\text { Rx reg- } \\
\text { imen } \\
\text { work? } \\
\\
\end{array}$} & $\begin{array}{l}\text { Healed } \\
\text { with Rx } \\
\pm \text { limited } \\
\text { surgical } \\
\text { debride- } \\
\text { ment, } \\
12 \\
\text { months }\end{array}$ & $\begin{array}{l}131 / 132 \\
(99 \%)^{\mathrm{e}}\end{array}$ & \multirow{5}{*}{$\begin{array}{l}\text { RFP-based all-oral } \\
\text { regimens com- } \\
\text { bined with lim- } \\
\text { ited surgical de- } \\
\text { bridement as need- } \\
\text { ed were associat- } \\
\text { ed with high heal- } \\
\text { ing rate and no } \\
\text { recurrence at } 12 \\
\text { - months. } 77 \% \text { of } \\
\text { participants healed } \\
\text { with Rx alone. } \\
\text { Some lesions may } \\
\text { need less than } \\
8 \text { weeks of Rx to } \\
\text { achieve healing. } \\
\text { - These were less se- } \\
\text { vere patients, as } \\
\text { patients who re- } \\
\text { quired extensive } \\
\text { surgical excision } \\
\text { were excluded. No } \\
\text { - independent re- } \\
\text { sults were given for } \\
\text { different regimens. }\end{array}$} \\
\hline & & & & & & & & & & & & $\begin{array}{l}\text { Healed } \\
\text { with } \mathrm{Rx} \\
\text { alone, } \\
12 \\
\text { months }\end{array}$ & $\begin{array}{l}101 / 132 \\
(76.5 \%)\end{array}$ & \\
\hline & & & & & & & & & & & & $\begin{array}{l}\text { Median } \\
\text { duration } \\
\text { of thera- } \\
\text { py }\end{array}$ & $\begin{array}{l}56 \\
\text { days } \\
\text { (IQR } 24 \\
\text { to } 96 \\
\text { days) }\end{array}$ & \\
\hline & & & & & & & & & & & & $\begin{array}{l}\text { Duration } \\
\text { of ther- } \\
\text { apy:<8 } \\
\text { weeks }\end{array}$ & $\begin{array}{l}22 / 132 \\
(16.7 \%)\end{array}$ & \\
\hline & & & & & & & & & & & & $\begin{array}{l}\text { Recur- } \\
\text { rence, } \\
12 \\
\text { months }\end{array}$ & None & \\
\hline \multirow{2}{*}{$\begin{array}{l}\text { Combi- } \\
\text { nation } \\
\text { of RFP, } \\
\text { CIPRO, } \\
\text { CAM, } \\
\text { ETB, } \\
\text { MOX, } \\
\text { AMK }\end{array}$} & \multirow[t]{2}{*}{$\begin{array}{l}\text { O'Brien } \\
2012\end{array}$} & \multirow[t]{2}{*}{ POS } & \multirow{2}{*}{$\begin{array}{l}\text { 2 groups: } \\
\text { 1. All-oral } \\
\text { Rx }(8 \\
\text { differ- } \\
\text { ent reg- } \\
\text { imens: } \\
\text { see be- } \\
\text { low) + } \\
\text { surgery }\end{array}$} & \multirow[t]{2}{*}{ All } & \multirow[t]{2}{*}{ None } & \multirow[t]{2}{*}{$Y$} & \multirow[t]{2}{*}{$133^{f}$} & \multirow[t]{2}{*}{$67: 66$} & \multirow[t]{2}{*}{$\begin{array}{l}\text { Medi- } \\
\text { an } 62 \\
\text { years } \\
\text { (3 to } \\
94)\end{array}$} & \multirow[t]{2}{*}{$\begin{array}{l}\text { Ulcer: } \\
106 \\
(87 \%)\end{array}$} & \multirow{2}{*}{$\begin{array}{l}\text { Is all- } \\
\text { oral Rx } \\
\text { treat- } \\
\text { ment } \\
\text { plus } \\
\text { surgery } \\
\text { supe- } \\
\text { rior to } \\
\text { just } \\
\text { surgery? }\end{array}$} & $\begin{array}{l}\text { Healed, } \\
12 \\
\text { monthsg }\end{array}$ & $\begin{aligned} & \text { 1. } 90 / 90 \\
&(100 \%) \\
& \text { 2. } 33 / 47 \\
&(70 \%)^{\natural}\end{aligned}$ & \multirow{2}{*}{$\begin{array}{l}\text { The tested all- } \\
\text { o) oral regimen plus } \\
\text { surgery was asso- } \\
\text { h ciated with } 100 \% \\
\text { healing and no } \\
\text { recurrence at } 12 \\
\text { months. } 30 \% \text { of } \\
\text { participants who } \\
\text { only had surgery } \\
\text { had recurrence. In- }\end{array}$} \\
\hline & & & & & & & & & & & & $\begin{array}{l}\text { Recur- } \\
\text { rence, } \\
12 \\
\text { monthsg }\end{array}$ & $\begin{aligned} \text { 1. } & 0 / 90 \\
& (0 \%) \\
\text { 2. } & 14 / 47 \\
& (30 \%)^{i}\end{aligned}$ & \\
\hline
\end{tabular}




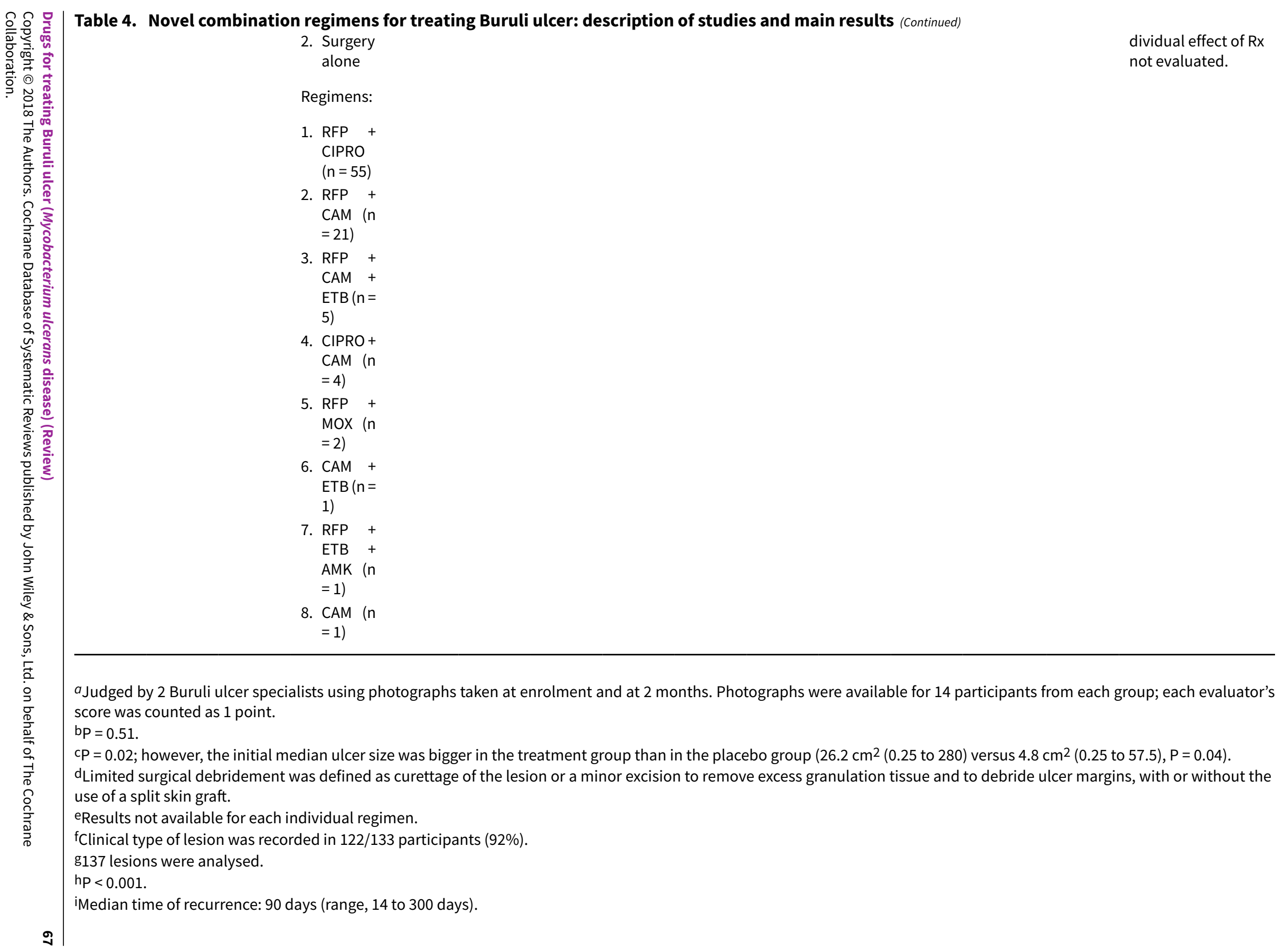


Abbreviations: AMK, amikacin; DDS, dapsone; CAM, clarithromycin; CIPRO, ciprofloxacin; ETB, ethambutol; IQR, interquartile range; Lab, laboratory confirmation; MOX, moxifloxacin; NR, not reported; POS, prospective observational study; RCT, randomized controlled trial; RFP, rifampicin; Rx, treatment; SM, streptomycin.

\section{Table 5. Paradoxical reactions in Buruli ulcer: description of studies and main results}

\begin{tabular}{|c|c|c|c|c|c|c|c|c|c|c|c|}
\hline $\begin{array}{l}\text { Regi- } \\
\text { men }\end{array}$ & Study & Design & Comparisons & Surgery & $\mathbf{N}$ & $\begin{array}{l}\text { Sex } \\
(M: F)\end{array}$ & Age & $\begin{array}{l}\text { Lesion } \\
\text { types }\end{array}$ & $\begin{array}{l}\text { Inci- } \\
\text { dence of } \\
\text { PR }\end{array}$ & $\begin{array}{l}\text { Onset } \\
\text { time of } \\
\text { PR }\end{array}$ & Our observation \\
\hline $\begin{array}{l}\text { RFP and } \\
\text { SM }\end{array}$ & $\begin{array}{l}\text { Sarfo } \\
2010\end{array}$ & POS & $\begin{array}{l}1 \text { group: RFP + SM } \\
\text { for } 8 \text { weeks (8RS) }\end{array}$ & $\begin{array}{l}\text { When in- } \\
\text { dicated } \\
\text { (post-Rx) }\end{array}$ & 160 & $66: 94$ & $\begin{array}{l}\text { Median } \\
12 \text { years } \\
\text { ( } 1 \text { to } 75)\end{array}$ & $\begin{array}{l}\text { Ulcer: } 86 \\
(54 \%) \\
\begin{array}{l}\text { Nodule: } 36 \\
(22 \%)\end{array} \\
\text { Plaque: } 14 \\
(9 \%) \\
\text { Oedema: } 24 \\
(15 \%)\end{array}$ & $\begin{array}{l}3 / 159 \\
(1.9 \%)^{a}\end{array}$ & $\begin{array}{l}\text { At weeks } \\
4,6,12\end{array}$ & $\begin{array}{l}\text { Approximately } 1 \text { in } 20 \\
\text { participants treated with } \\
8 \text { RS developed PR. } 2 \\
\text { cases occurred during } \\
\text { Rx and } 1 \text { case occurred } \\
\text { post-Rx. }\end{array}$ \\
\hline $\begin{array}{l}\text { RFP and } \\
\text { SM } \\
\text { or } \\
\text { RFP and } \\
\text { SM } \\
\text { plus } \\
\text { RFP and } \\
\text { CAM }\end{array}$ & $\begin{array}{l}\text { Barogui } \\
2016\end{array}$ & POS & $\begin{array}{l}\text { 1 group: } \\
\text { 1. RFP + SM for } 8 \\
\text { weeks }(n=166) \\
\text { 2. RFP + SM for } \\
4 \text { weeks fol- } \\
\text { lowed by RFP } \\
+ \text { CAM for } 4 \\
\text { weeks }(n=75)\end{array}$ & $\begin{array}{l}\text { When in- } \\
\text { dicated }\end{array}$ & 241 & $88: 153$ & $\begin{array}{l}\text { Mean } \\
(\mathrm{SD}) \\
16(13) \\
\text { years }\end{array}$ & $\begin{array}{l}\text { Ulcer: } 108 \\
(45 \%) \\
\text { Nodule: } 32 \\
(13 \%) \\
\text { Plaque: } 56 \\
(23 \%) \\
\text { Oedema: } 11 \\
(5 \%) \\
\text { Mixed: } 34 \\
(14 \%)\end{array}$ & $\begin{array}{l}52 / 241 \\
(22 \%)^{b}\end{array}$ & $\begin{array}{l}\text { Between } \\
\text { week } 8 \\
\text { and } 12\end{array}$ & $\begin{array}{l}\text { Approximately } 1 \text { in } 5 \\
\text { participants treated with } \\
\text { Rx developed PR be- } \\
\text { tween week } 8 \text { and } 12 \text {. }\end{array}$ \\
\hline $\begin{array}{l}\text { RFP and } \\
\text { SM } \\
\text { plus } \\
\text { RFP and } \\
\text { CAM }\end{array}$ & $\begin{array}{l}\text { Phillips } \\
\text { 2014a }\end{array}$ & POS & $\begin{array}{l}1 \text { group: RFP + SM } \\
\text { for } 2 \text { weeks }(2 R S) \\
\text { followed by RFP + } \\
\text { CAM for } 6 \text { weeks } \\
(6 R C)\end{array}$ & $\begin{array}{l}\text { When in- } \\
\text { dicated }\end{array}$ & 43 & $18: 25$ & $\begin{array}{l}\text { Median } \\
14 \text { years } \\
(5 \text { to } 70)\end{array}$ & $\begin{array}{l}\text { Ulcer: } 20 \\
(47 \%) \\
\text { Nodules: } 14 \\
(32 \%) \\
\text { Plaque: } 9 \\
(21 \%)\end{array}$ & $\begin{array}{l}4 / 41 \\
(9.3 \%)^{c}\end{array}$ & $\begin{array}{l}\text { Median } \\
12 \text { weeks } \\
\text { (range, } \\
4 \text { to } 32 \\
\text { weeks) }\end{array}$ & $\begin{array}{l}\text { Approximately } 1 \text { in } 10 \\
\text { participants treated with } \\
2 \mathrm{RS}+6 \mathrm{RC} \text { developed } \mathrm{PR} \\
\text { at median } 12 \text { weeks af- } \\
\text { ter start of treatment. }\end{array}$ \\
\hline $\begin{array}{l}\text { Combi- } \\
\text { nation }\end{array}$ & $\begin{array}{l}\text { O'Brien } \\
2012\end{array}$ & POS & $\begin{array}{l}8 \text { groups: Weeks } \\
\text { of }\end{array}$ & All & 90 & NR & NR & NR & $\begin{array}{l}8 / 90 \\
(8.9 \%) \mathrm{d}\end{array}$ & $\begin{array}{l}\text { Median } \\
48 \text { days }\end{array}$ & $\begin{array}{l}\text { Approximately } 1 \text { in } 10 \\
\text { participants treated with }\end{array}$ \\
\hline
\end{tabular}

RFP + SM for 8

RFP + SM for

lowed by RFP

+ CAM for 4 


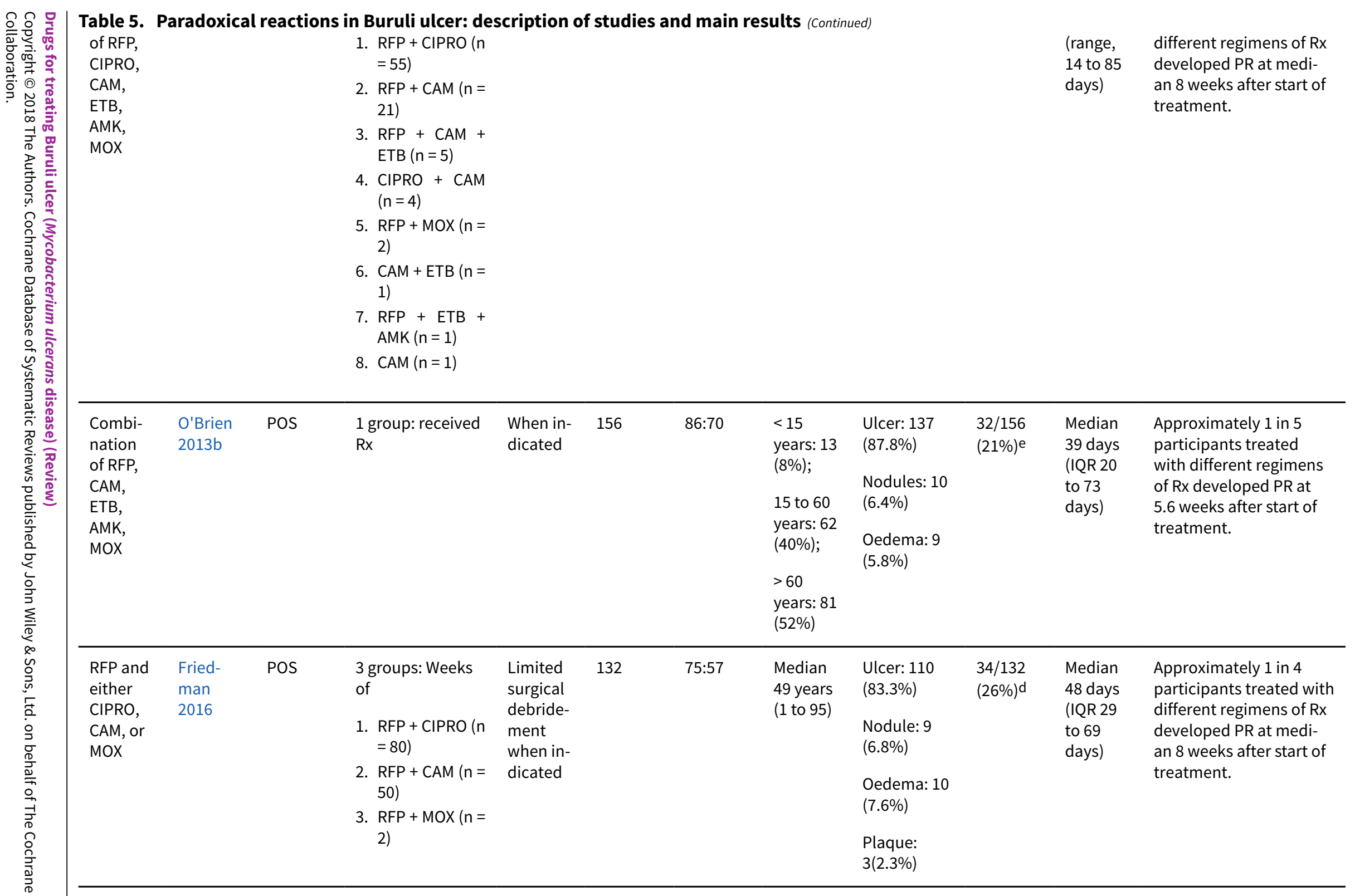

${ }^{a}$ One death.

b37/166 (22\%) received RFP + CIPRO; 15/75 (20\%) received RFP + CAM.

C2 participants lost to follow-up.

\& dResults not available for each individual regimen. 
ePredictors of paradoxical reactions (multivariable analysis): age $\geq 60$ years (risk ratio (RR) 2.84, 95\% confidence interval (CI) 1.12 to $7.17 ; \mathrm{P}=0.03$ ), oedematous lesion (RR 3.44 , $95 \% \mathrm{Cl} 1.11$ to $10.70 ; \mathrm{P}=0.03$ ), use of amikacin in the initial $\mathrm{Rx}$ regimen ( $\mathrm{RR} 6.33,95 \% \mathrm{Cl} 2.09$ to $19.18 ; \mathrm{P}<0.01$ ).

Abbreviations: AMK, amikacin; CAM, clarithromycin; CIPRO, ciprofloxacin; ETB, ethambutol; IQR, interquartile range; Lab, laboratory confirmation; MOX, moxifloxacin; NR, not reported; POS, prospective observational study; PR, paradoxical reactions; RCT, randomized controlled trial; RFP, rifampicin; Rx, treatment; SD, standard deviation; SM,

streptomycin. 


\section{AP PE N D I C E S}

\section{Appendix 1. Search strategy}

\begin{tabular}{|c|c|c|c|c|c|}
\hline Search set & CIDG SR 1 & CENTRAL & MEDLINE & Embase & LILACS \\
\hline 1 & Buruli ulcer* & $\begin{array}{l}\text { "Buruli Ul- } \\
\text { cer"[Mesh] OR } \\
\text { "Mycobacteri- } \\
\text { um ulceran- } \\
\text { s"[Mesh] }\end{array}$ & $\begin{array}{l}\text { "Buruli Ulcer"[Mesh] OR } \\
\text { "Mycobacterium ulceran- } \\
\text { s"[Mesh] }\end{array}$ & $\begin{array}{l}\text { Buruli ulcer (Emtree) OR Buruli } \\
\text { ulcer }{ }^{\star} \text { ti, ab }\end{array}$ & Buruli ulcer* \\
\hline 2 & $\begin{array}{l}\text { Mycobacteri- } \\
\text { um ulcerans }\end{array}$ & $\begin{array}{l}\text { Buruli ulcer* } \\
\text { ti, ab }\end{array}$ & Buruli ulcer* ti, ab & $\begin{array}{l}\text { Mycobacterium ulcerans } \\
\text { [Emtree] }\end{array}$ & $\begin{array}{l}\text { Mycobacteri- } \\
\text { um ulcerans }\end{array}$ \\
\hline 3 & 1 or 2 & $\begin{array}{l}\text { Buruli AND } \\
\text { skin ti, ab }\end{array}$ & Buruli AND skin ti, ab & Buruli AND skin ti, ab & 1 or 2 \\
\hline 4 & - & 1 or 2 or 3 & $\begin{array}{l}\text { "Mycobacterial skin ul- } \\
\text { cer }^{\star "} \text { or "mycobacterium } \\
\text { skin ulcer*" ti, ab }\end{array}$ & $\begin{array}{l}\text { "Mycobacterial skin ulcer*" or } \\
\text { "mycobacterium skin ulcer*" ti, } \\
\text { ab }\end{array}$ & - \\
\hline 5 & - & - & 1 or 2 or 3 or 4 & 1 or 2 or 3 or 4 & - \\
\hline 6 & - & - & $\begin{array}{l}\text { randomized controlled tri- } \\
\text { al.pt. OR controlled clini- } \\
\text { cal trial.pt. }\end{array}$ & $\begin{array}{l}\text { Clinical trial or Randomized } \\
\text { controlled trial or Randomiza- } \\
\text { tion or Single blind procedure } \\
\text { or Double blind procedure or } \\
\text { Crossover procedure or Placebo } \\
\text { OR prospective study [Emtree] }\end{array}$ & - \\
\hline 7 & - & - & $\begin{array}{l}\text { "Prospective Stud- } \\
\text { ies"[Mesh] }\end{array}$ & $\begin{array}{l}\text { Randomi?ed controlled tri- } \\
\text { al }^{\star} . \text { tw. }\end{array}$ & - \\
\hline 8 & - & - & $\begin{array}{l}\text { randomized.ab. or place- } \\
\text { bo.ab. }\end{array}$ & Random or randomly. $\mathrm{Ti}, \mathrm{ab}$ & - \\
\hline 9 & - & - & $\begin{array}{l}\text { randomly.ab. or trial.ab. } \\
\text { or groups.ab. }\end{array}$ & Placebo* ti, ab & - \\
\hline 10 & - & - & $\begin{array}{l}\text { treatment OR therap }{ }^{\star} \text { ti, } \\
\mathrm{ab}\end{array}$ & treatment OR therap* ti, ab & - \\
\hline 11 & - & - & 6 or 7 or 8 or 9 or 10 & 6 or 7 or 8 or 9 or 10 & - \\
\hline 12 & - & - & 5 and 11 & 5 and 11 & - \\
\hline
\end{tabular}

${ }^{1}$ Cochrane Infectious Diseases Group Specialized Register.

\section{CONTRIBUTIONS OF AUTHORS}

Rie Roselyne Yotsu conceived the review question, extracted and analysed data, and co-ordinated and drafted the protocol and review. Marty Richardson extracted and analysed data, provided statistical advice, and edited the protocol and review. Norihisa Ishii supervised the clinical content and approved the final version prior to submission. 


\section{DECLARATIONS OF INTEREST}

Rie Roselyne Yotsu acts as a WHO consultant for leprosy and also has financial support for an epidemiological study on Buruli ulcer in Cote d'Ivoire and in Ghana. However, there are no financial relationships with any organizations that might have an interest in the submitted work in the previous three years; and no other relationships or activities that could appear to have influenced the submitted work.

Marty Richardson has no known conflicts of interest.

Norihisa Ishii has no known conflicts of interest.

\section{SOURCES OF SUPPORT}

\section{Internal sources}

- Liverpool School of Tropical Medicine, UK.

\section{External sources}

- The Japan Agency for Medical Research and Development, Japan.

Material support for field research on leprosy/Buruli ulcer in Cote d'Ivoire (18jm0510004h0001)

- The Sasakawa Memorial Health Foundation, Japan.

Material support for field research on leprosy/Buruli ulcer in Cote d'Ivoire

- Department for International Development, UK.

Project number 300342-104

\section{DIFFERENCES BETWEEN PROTOCOLANDREVIEW}

We did not include the planned methods for conducting meta-analyses in the review due to the small number of included studies and their heterogeneity.

We added paradoxical reactions to the Secondary outcomes.

We revised the 'Risk of bias' assessment. The method stated in the protocol was only applicable to randomized controlled trials and not to prospective observational studies.

We added the following search terms: 'Buruli and skin', 'mycobacterial skin ulcer`', and 'mycobacterium skin ulcer'.

\section{N DEX TERMS}

\section{Medical Subject Headings (MeSH)}

Anti-Bacterial Agents [ ${ }^{\star}$ therapeutic use]; Buruli Ulcer [complications] [ ${ }^{\star}$ drug therapy] [surgery]; Clarithromycin [therapeutic use]; Clofazimine [therapeutic use]; Drug Therapy, Combination; Mycobacterium ulcerans; Observational Studies as Topic; Randomized Controlled Trials as Topic; Rifampin [therapeutic use]; Streptomycin [therapeutic use]; Trimethoprim, Sulfamethoxazole Drug Combination [therapeutic use]

\section{MeSH check words}

Humans 